\title{
Welfare to Temporary Work: Implications for Labor Market Outcomes
}

\author{
Carolyn J. Heinrich \\ LaFollette School of Public Affairs and \\ the Institute for Research on Poverty \\ University of Wisconsin-Madison \\ Peter R. Mueser \\ Department of Economics \\ University of Missouri-Columbia \\ Kenneth R. Troske \\ Department of Economics \\ University of Missouri-Columbia and IZA
}

July 2003

Helpful comments were provided by participants in the 2002 Midwest Economics Association Meetings, the First IZA/SOLE Transatlantic Meeting of Labor Economics, and a seminar at the University of North Carolina-Chapel Hill. We wish to express particular thanks for Tom Mroz, Joe Tracy and Tim Bartik. Chao Gu, Andrew Dyke and Kyung-Seong Jeon provided excellent research assistance. This work was supported by a grant from the Rockefeller/Russell Sage Future of Work program. Any errors are our own. 


\begin{abstract}
We explore the effects of temporary help employment on welfare recipients'subsequent employment and welfare dynamics. We find that any employment-in temporary help services or other sectors-yields substantial benefits compared to no employment. Although welfare recipients who go to work for temporary help service firms have lower initial wages than those with jobs in other sectors, they experience faster subsequent wage growth. Two years later, they are no less likely to be employed, their wages are close to those of other workers, and they are only slightly more likely to remain on welfare.
\end{abstract}




\section{Introduction}

Throughout the 1990s, the U.S. welfare system has been evolving from a system primarily focused on getting qualified individuals registered for cash assistance to one that aims to help disadvantaged individuals obtain self-sufficiency through employment. Rather than focusing solely on documenting eligibility, case workers now must develop a program of training and employment counseling that will place welfare recipients into jobs. As this has occurred, state and local welfare agencies and individuals in need of assistance have increasingly turned to labor market intermediaries, including temporary help service firms and other public and private employment agencies, as one way of connecting people with jobs (Pavetti et al., 2000).

Concerns are being raised, however, about the increased use of temporary help service firms for placing welfare recipients and other disadvantaged individuals into jobs. Jobs with temporary help service firms are frequently less stable, offer fewer fringe benefits, and pay lower wages than similar jobs in traditional (“end-user”) firms. Blank (1998) estimates that between 40 percent and 70 percent of temporary help service workers are in what she refers to as "problem" jobs, jobs that both pay low wages and are relatively less stable. At least one study finds that a majority of such workers state that they would prefer traditional employment arrangements (Cohany, 1998).

On the other hand, for many low-skilled workers employment through labor market intermediaries may provide a path to permanent and stable employment. By limiting the extent of employer commitment, such jobs may provide access to informal training and screening for workers who might otherwise be excluded from such opportunities. While a variety of studies 
present a picture of the kinds of workers in such positions, little is presently known about the role that temporary help service employment plays in the career trajectories of welfare recipients. ${ }^{1}$

To further examine the effect that temporary help service firms have on the labor market experiences and outcomes of welfare recipients, we address two main questions: Who among welfare recipients goes to work for temporary help service firms, and what are the implications of temporary employment for their labor market outcomes, compared to those welfare recipients who are hired directly by the firms in which they work? ${ }^{2}$ We address these questions using administrative data on all welfare recipients in Missouri and North Carolina and all employment covered by unemployment insurance in these two states. Our data on welfare recipients and employment begin in 1990 in Missouri and 1995 in North Carolina. These data include standard demographic information about individuals, such as age, race, sex and education, as well as total earnings in a quarter and the industry of their employers. Using a multinomial logit model we examine how differences in individual characteristics and past welfare and employment experience affect the probability of working in a temporary help job relative to either not working at all or working for a firm in an alternative industry. We compare the earnings, earnings growth, and patterns of welfare receipt of welfare recipients who work for temporary help service firms

${ }^{1}$ For studies characterizing temporary help employment, see Blank (1998), Cohany (1998), Laird and Williams (1996), Howe (1986), and a series of articles in the October 1996 Monthly Labor Review.

${ }^{2}$ Nollen (1996) defines two types of temporary workers: (1) employees of staffing/temporary help service firms who take short-term assignments at other client companies, and (2) direct-hire employees of the company where they work who have fixed-term contracts for temporary work. Our empirical analyses focus on the former, employees in the temporary help service industry, since our data allow us to identify industry of employment but not detailed job characteristics. Many of the issues we address are relevant for other temporary workers. 
with welfare recipients who either do not have jobs or who have jobs with end-user firms, controlling for individual characteristics. Finally, we compare the movement of welfare workers in temporary help firms across industries with the movement of workers who start out in other industries.

The paper is organized as follows. In the next section we review relevant literature and discuss theories about how individuals become matched to jobs in temporary help service firms. We describe our data in section III. In sections IV and V we present results. We summarize our results and present conclusions in section VI.

\section{Literature Examining the Characteristics of Temporary Workers}

Blank's (1998) findings on the low pay and instability associated with temporary work are corroborated in a number of studies that describe the characteristics of temporary work. Segal and Sullivan (1997a), for example, find that temporary workers are more likely than other workers to report being underemployed, to work fewer hours, and to have greater variability in their work schedules and less attachment to the labor force. They also report that temporary workers receive 28 percent lower wages than permanent workers. Nollen (1996) estimates that the average wages of temporary employees are 35 percent lower than workers in other occupations. Houseman and Polivka (1999) also find that workers in temporary arrangements are considerably more likely than regular part-time workers to change employers or to lose their jobs and leave the labor force, even when they say they would prefer to work. In addition, Cohany (1998) finds that whereas 61 percent of permanent (or "traditional") workers have health insurance only 7 percent of temporary workers receive this benefit. 
A case study of temporary workers reports that these workers cite a number of "problems" with these jobs, including: uncertainty about income, work hours, and travel costs; a resulting inability to plan, invest, get credit, or make child care arrangements; money paid up front for work clothes or safety equipment that might not be used more than a day; unfairly withheld wages and equipment charges; a lack of job skills training or useful feedback on job performance; marginal social interactions in the workplace and exploitative actions by temporary employers; fear that assignments might be withheld if workers' refused assignments, complained, or filed workers' compensation or unemployment insurance claims; and powerlessness in controlling working conditions (McAllister, 1998). Welfare recipients frequently face employment barriers related to child care, transportation, and limited personal and financial resources for coping with some of these contingencies (Berg, Olson and Conrad, 1991; Pavetti and Acs, 2001). It is possible that the problems frequently associated with temporary jobs may be compounded for welfare recipients, generating special obstacles to self-sufficiency.

An alternative view of temporary work is that workers may choose these jobs because temporary help jobs best match their preferences or skills. In addition, the nature of temporary work may benefit workers who want or need to take extended periods out of the labor force, or who value nonmarket time highly but are indifferent to its exact timing. For these people, the instability or uncertainty of temporary work may not be important disadvantages. This group might include some welfare recipients with young children or other family care responsibilities, and among temporary workers there may be a substantial proportion who fit this profile. Cohany (1998) and Morris and Vekker (2001) find that one in three temporary workers prefers their arrangement to a traditional job. Among married women with children, Morris and Vekker 
report that 25 percent indicated that they wanted a temporary job for flexibility, shorter hours, to facilitate child care arrangements, or for other family reasons.

In terms of individual characteristics, Segal and Sullivan (1997a) find that a large portion of the temporary/permanent wage gap can be explained by standard worker characteristics known to be related to wages, or to unmeasured permanent differences in earnings-related characteristics. In addition, in explaining the disproportionate representation of AfricanAmericans among temporary workers, Carre (1992) observes that the group of occupations in which African-American workers are concentrated in temporary employment corresponds to the occupations in which African-American workers are concentrated in all industries. Nollen (1996) likewise reports that the overall lower wages of temporary employees is a result of their concentration in relatively low-wage occupations (administrative, clerical, and laborer jobs). Thus, the higher concentration of welfare recipients (and other lower-skilled, less educated workers) in temporary help jobs may in fact reflect a matching process between workers with fewer productive characteristics and firms or jobs requiring less specific human capital, for which firms do not wish to establish long-term contracts.

Furthermore, for those workers with less desirable characteristics, the ability to enter into a contract where the employer has no long-term obligation may facilitate their access to the labor market. As Nollen (1996:575) explains, according to this view, "temporary work gives opportunities to begin the process of practical human capital development." These temporary jobs in firms that might not otherwise hire these workers could also allow workers a chance to show that they are productive and possibly lead to permanent jobs with the same employers. Based on their analysis of the frequency of transitions from temporary to permanent employment, 
Segal and Sullivan (1997a) find that the size of any "permanent 'underclass' of temporary workers" is likely small.

Previous research has a number of implications related to our analysis. First, to the extent that jobs in temporary help service firms have attributes that better match the preferences and/or skills of welfare recipients, workers in temporary help jobs will tend to be younger, less educated, and more likely to be nonwhite. Also, we expect that workers in temporary help jobs are more likely to have young children.

We also expect that workers in temporary help jobs will tend to have lower initial wages relative to workers in other industries. Insofar as temporary help jobs facilitate matches between workers and firms that lead to stable, long-term employment relationships, we expect earnings for these workers to increase faster than for others. On the other hand, it may be that temporary help jobs, along with low-wage jobs in general, provide poor future prospects. Houseman and Polivka (1999) find that temporary workers are more likely to lose their jobs than workers in other industries. Bartik's (1997) analysis shows that this is also the case among welfare recipients. If those welfare recipients who go to work in permanent positions stay on the job longer, benefitting from more work experience and opportunities for general or firm-specific skills training, we might expect to see this reflected in higher subsequent earnings and earnings growth rates, compared to those who take temporary jobs.

In addition, it may be that welfare recipients are being forced to accept jobs in temporary help, and that these jobs lack the attributes that previous research suggests are crucial to their successful transition off of welfare and into stable employment — health insurance benefits, paid time off from work, stable income, and supportive relationships with co-workers and supervisors 
(Blank, 1998; Cohany, 1998; Jorgenson and Riemer, 2000; Morris and Vekker, 2001). Workers in temporary help jobs will then be less likely to leave welfare in the future than workers in other industries, and they may have earnings that are persistently below the earnings of workers in other industries. Nonetheless, relative to those not working, welfare recipients who work in temporary help jobs may have a greater chance of moving off of welfare in subsequent periods.

Two recent studies suggest that temporary jobs do not have serious adverse impacts on employment and earnings prospects. In a study of British temporary workers, Booth et al. (2002) estimate that the impact on current earnings of holding a temporary job is generally less than 10 percent after controlling for the endogeniety of job choice. For men in temporary jobs, a small earnings difference remains indefinitely even if they find permanent jobs, but women experience no long-run earnings loss. Lane et al. (forthcoming) use a matching technique to examine the impacts of entry into temporary help employment on earnings, employment and welfare receipt a year later. This approach, which controls for a variety of measured characteristics, shows slightly lower levels of employment and earnings a year later for those who initially obtain temporary jobs as compared with those in traditional jobs. There are no significant differences in welfare receipt, although inferences are limited by the small number of recipients. Those with any job, whether temporary or traditional, have much better prospects than those without jobs.

\section{Data}

Our analysis examines cash recipients in the Aid to Families with Dependent Children (AFDC) or Temporary Assistance for Needy Families (TANF) programs in the states of Missouri and North Carolina. Our data come from records maintained to administer the states' welfare 
programs, providing basic demographic and family information on recipient households. We focus on female payees, age 18 but less than 65 years, in single parent households and exclude "child only" cases. ${ }^{3}$ In most of our analyses, we use quarters as our time unit, so that an individual who receives AFDC or TANF cash payments at any point during a given quarter is considered a welfare recipient.

Our examination of employment for welfare recipients relies on earnings data collected by the states in support of their unemployment insurance programs. Employers report total earnings for each individual in covered employment during each quarter, and we merge this information with records of welfare recipients. In addition to earnings, employer industry and several other employer characteristics are available. While these data omit self-employment, illegal or informal employment, and a small number of jobs not covered by unemployment insurance, the overwhelming majority of employment within each state is included. For welfare recipients in Missouri, we use employment data collected by the states of Missouri and Kansas, ensuring employment coverage for welfare recipients in Kansas City, Missouri, who often work in Kansas. ${ }^{4}$ For welfare recipients in North Carolina, we use that state's employment data. Of

${ }^{3}$ The payee in a child only case is not a parent and receives payment on behalf of the children. Such payees normally do not face work or training requirements, and their income does not count in the calculation of the benefits.

${ }^{4}$ Approximately one in seven jobs held by welfare recipients in Jackson County (the central county in the Kansas City metropolitan area) is in Kansas. In St. Louis, the proportion of individuals holding jobs in Illinois is much lower, reflecting the relatively poor economy in East St. Louis. 
course, employment will be understated for individuals who move out of state after leaving welfare..$^{5}$

Table 1 provides information on the sample of welfare recipients who serve as the basis for our analysis. In Missouri, our sample consists of all welfare recipients during 1993 and 1997, while the sample in North Carolina is for 1997. The sampling frame is quarters of welfare receipt, so individuals appear once for each quarter during each year in which they received welfare. This approach assures that the measures are representative of the average caseload during the year. ${ }^{6}$

Among the standard demographic measures, race shows the greatest differences over time and between states. The proportion of nonwhite welfare recipients is nearly 20 percentage points higher in North Carolina than in Missouri. Over the four years covered by our data in Missouri, the proportion nonwhite grows by 4 percentage points. More of the Missouri recipients are high school dropouts than are recipients in North Carolina. Missouri welfare recipients are slightly older, have more children, and their children are older in 1997, but these differences are small.

${ }^{5}$ Kornfeld and Bloom (1997) compare experimental (job-training program) earnings impact estimates calculated using unemployment insurance (UI) data with those based on other more costly earnings data sources and conclude that UI wage data provide valid estimates for all low income persons except a small subgroup of male youth with past arrests. See Hotz and Scholz (2002) for a general discussion of the advantages and limitation of these data for studying the employment patterns of welfare recipients.

${ }^{6}$ We are using data from 1997 for both Missouri and North Carolina because we want to have information for workers for two years prior to and two years following the sample period. Our data in North Carolina begin in 1995, so 1997 is the first year we have the retrospective information. Since the Missouri data begin in 1990, we are also able to use data for welfare recipients in 1993. 
Among the most important differences between states is the settlement density. Over 50 percent of Missouri's welfare recipients live in the central counties of large metropolitan areas (St. Louis and Kansas City), whereas in North Carlina, less than 15 percent live in Charlotte, the state's only large metropolitan area. Approximately half of North Carolina's caseload is in small metropolitan areas, in contrast to less than 10 percent for Missouri. ${ }^{7}$ Reflecting settlement patterns in the south, North Carolina has a larger proportion living outside any metropolitan area-nearly 40 percent, in contrast to approximately 25 percent in Missouri.

\section{Employment, Earnings, and Welfare Exit of Welfare Recipients}

\section{Characteristics of Welfare Recipients by Job Sector}

We begin our analysis of the effect that temporary help services firms have on the labor market experience of welfare workers by looking at how the characteristics of welfare recipients vary by job sector. Throughout this analysis we divide workers into three main groups based on their employment during a quarter: (1) those with no job, (2) those with jobs in only one of our sectors, and (3) those with jobs in multiple sectors. ${ }^{8}$ We further divide the second group by

${ }^{7}$ The observed difference is due to the category breaks in conjunction with the fact that there are more moderately large metropolitan centers in North Carolina. According to 2000 Census statistics, two of the metropolitan areas classified as "small" in North Carolina have total populations greater than 1 million (Greensboro-Winston-Salem-High Point and Raleigh-Durham-Chapel Hill). In contrast, none of the metropolitan areas classified as small in Missouri has a population over 400,000. Our classification is based on the system developed by the United States Department of Agriculture Economic Research Service.

${ }^{8}$ Our wage record data allow us identify the earnings that an individual receives from each employer in a quarter. However, for individuals with earnings from multiple employers, we do not know whether employment was simultaneous or sequential. Recipients are classified as not having a job if they do not appear in the earnings data. 
sector: temporary help, manufacturing, retail trade, services (not temporary help), and any other industry. ${ }^{9}$ Finally, we divide workers with jobs in more than one sector into those who have at least one job in the temporary help sector, and those who do not have a job in the temporary help sector. In Table 2, we present the characteristics of Missouri and North Carolina welfare recipients separately by type of job.

Comparing recipients with no job to those with a job in the temporary help sector only, we see that welfare recipients who do not have a job are less educated, are more likely to be white, have longer spells on welfare, and work a smaller percentage of time in the previous eight quarters. These differences are similar for welfare recipients in both Missouri and North Carolina.

Comparing welfare recipients with jobs in temporary help with other employed welfare recipients, we see that recipients working in temporary help are much more likely to be nonwhite. In addition, temporary help workers have slightly longer spells on welfare and work a smaller percentage of time in the previous eight quarters. However, with the exception of race, the differences in characteristics between recipients working in temporary help jobs and recipients working in other sectors are much smaller than the differences in characteristics between those with jobs and those without.

Earnings of Welfare Recipients by Job Type

${ }^{9}$ This division is based on the SIC code of the employer. The temporary help sector is SIC code 7363. Manufacturing includes SIC codes 20-39, retail trade includes SIC codes 52-59, and services includes SIC codes 70-89. Workers in all other industries are included in the "other" category. 
Table 3 presents the mean earnings of welfare recipients by type of employment. Since workers with no job have zero earnings by definition, we have excluded them from this table. Comparing the earnings of welfare recipients working in temporary help jobs with recipients working in other industries, we see that the mean earnings of workers in temporary help jobs is substantially below the mean earnings of workers in other sectors. In Missouri in 1997, welfare recipients working in the temporary help sector average 40 percent lower earnings than workers in manufacturing, while in North Carolina workers in the temporary help sector have average earnings that are one-third lower than workers in manufacturing. While the differences tend to be smaller when comparing the average earnings of temporary help workers with the average earnings of workers in other industries, the difference is always at least $\$ 100$, which translates into at least 10 percent lower average earnings for welfare recipients working in the temporary help sector.

One other interesting comparison in Table 3 is between recipients who hold jobs in multiple sectors, one of which is in the temporary help sector, and recipients who hold jobs in multiple sectors but none in the temporary help sector. Although those with jobs in temporary help have lower earnings, the difference is generally less than 10 percent. One hypothesis that might account for this pattern is that those with both types of jobs may take a job in the temporary help sector because the flexibility of a temporary help job may lower the costs of having more than one job. In contrast, recipients with just one job in the temporary help industry may have lower skills and may therefore take a job in the temporary help industry because temporary jobs better match their skills. 
Table 4 presents employment and earnings information over the next two years for welfare recipients separately by type of current job. In both Missouri and North Carolina, we see that recipients with no current job have substantially lower earnings over the next two years than any class of workers and have fewer quarters in which they have positive earnings. We also see that, relative to recipients working in other sectors, recipients with a job only in the temporary help sector tend to have lower earnings over the next two years. However, it is important to note that the difference in the sum of earnings between workers in the temporary help sector and workers in other sectors is much smaller than the difference in current earnings reported in Table 3. The average sum of earnings over the next two years for welfare recipients in Missouri in 1997 whose job is in the temporary help sector is 14 percent less than welfare recipients whose job is in manufacturing. In contrast, we saw in Table 3 that the average current earnings of recipients in the temporary help sector was 40 percent lower than average current earnings of recipients working in manufacturing. This implies that recipients working in the temporary help sector have considerably higher rates of earnings growth over the next two years than recipients in the manufacturing sector. We see a similar pattern when we compare the earnings of temporary help workers to the earnings of workers in other industries.

Equally notable, we see that among individuals who are observed initially to have jobs in multiple sectors, those with a temporary help job actually have higher earnings than others in the subsequent two years, in contrast to their current earnings, which are lower. The finding that welfare recipients working in the temporary help sector have lower current earnings but faster earnings growth relative to recipients working in other sectors is consistent with the hypothesis that the reason workers accept jobs in the temporary help sector is because these jobs allow them 
to demonstrate to employers that they are productive, ultimately leading to more stable, higherpaying jobs.

\section{Future Welfare Receipt}

Table 5 presents statistics on welfare receipt over the subsequent two years, again broken out by the type of job held (or no job) in the current quarter and year of observation. In both Missouri and North Carolina, we see that a larger percentage of recipients with no job are still on welfare in two years as compared with those holding any job, and recipients with no job receive welfare payments in more quarters over the next two years. When we compare recipients with a job only in temporary help to other employed recipients, we see that recipients working in temporary help are also more likely to be on welfare in two years and to receive welfare payments in more quarters over the next two years. Welfare recipients who have a job only in the temporary help sector are less likely to leave welfare than recipients who have a job in another sector or who have jobs in multiple sectors. However, relative to welfare recipients with no job, recipients working in the temporary help industry are less likely to be on welfare two years later and receive fewer quarters of welfare over the period. Finally looking at the data for Missouri we see that for all industry groups, the percent on welfare two years later is lower for the more recent cohorts.

In summary, Tables 2-5 suggest that recipients with any job, including those with jobs in temporary help services, tend to be more skilled, have been on welfare for less time, and are more likely to move off of welfare in the future than those with no jobs. However, relative to recipients working in other sectors, recipients with jobs only in the temporary help sector tend to be less skilled, are less likely to leave welfare, have lower current earnings, but experience faster 
growth in earnings in the next two years. These findings are all consistent with the hypothesis that welfare recipients obtain opportunities for future advancement by working in the temporary help sector. Of course, up to this point, we have not controlled for other characteristics of workers that might affect their earnings and employment and welfare patterns in our analysis. It is this more in-depth analysis that we turn to next.

\section{Determinants of Employment, Earnings and Welfare Receipt}

\section{Determinants of Job Type}

We begin by examining the relationship between welfare recipient characteristics and the type of job. We estimate a multinomial logit model, where the types of jobs an individual can have are: no job; a job in the temporary help sector only ("Job in Temp Help"); a job both in the temporary help sector and in another industry ("Job in Temp Help and Other Industry"); a job in another industry but no job in the temporary help sector ("Job, but None in Temp Help"). No job is the excluded category in this analysis, so all of the effects are relative to not having a job.

We estimate the multinomial logit model controlling for the set of demographic characteristics discussed previously (age, education, nonwhite, number of children and age of the youngest child) as well as measures of past welfare experience, labor market experience, and prior earnings. ${ }^{10}$ We also control for the quarter of the year from which the observation comes

\footnotetext{
${ }^{10}$ Previous studies indicate that controls for labor market experience and prior earnings are particularly important, as they correlate strongly with unobserved characteristics related to future employment and earnings (Houseman and Polivka, 1999; Segal and Sullivan, 1997b; Heckman, Ichimura, Smith and Todd, 1998).
} 
and a variety of characteristics of the county where an individual lives. In addition to the county's metropolitan status, we control for the county's sanction rate and welfare departure rate. County-specific measures of the economy include the county's employment level, the share of employment in nine primary industries and the average earnings in each.

The results from our multinomial logit analysis are presented in Table 6. Looking at the coefficients in this table, we see that, with a few notable exceptions, the effects of individual characteristics are very similar across the three types of jobs, relative to not having a job. Perhaps the most striking exception, however, is the large difference in probabilities by race across job types. The probability that a welfare recipient has a job in the temporary help sector is substantially higher for nonwhites than for whites, while there is relatively little difference by race in the likelihood of obtaining other jobs. In addition, contrary to our expectations, older workers are relatively more likely to have jobs in the temporary help sector than jobs in another industry, although this effect is smaller in the most recent period. ${ }^{11}$

As expected, there are important differences by geographical location. Here we see that living in a metropolitan area significantly increases the probability that a recipient has any type of temporary help job relative to not having a job or to having a job in another industry. (This relationship is somewhat more pronounced in Missouri than in North Carolina.) This effect is in addition to the strong impacts of measures reflecting the local economy. As might be expected, greater levels of overall employment in the county imply a greater chance of temporary employment—especially where temporary employment is combined with other kinds of

\footnotetext{
${ }^{11}$ We examine the impact of age at the sample mean, based on the coefficients for the linear and squared terms.
} 
employment. We see that high levels of construction, manufacturing, wholesale trade and resale trade employment increase the likelihood of a temporary help job. Earnings by industry also have statistically significant impacts, although effects are difficult to summarize. As might be expected, higher earnings in the industries listed above do not generally increase the likelihood of a temporary help job, suggesting that it is the lower-paying firms in these industries that are most likely to hire temporary help workers.

It is worthwhile to note that these results fail to support the view that women with more demanding family responsibilities are more likely to take temporary help jobs. It appears that individuals with more children or with younger children are no more likely to be in temporary help jobs than other jobs.

\section{Determinants of Earnings}

The analyses above (Tables 3 and 4) show that those with jobs in temporary help service firms have initial earnings that are appreciably below those with jobs in most other major industry categories but that the difference in earnings between these groups declines in the following eight quarters. Several problems arise in attempting to identify whether this relationship is causal. The first problem is that individuals who take temporary help jobs may have different measured characteristics than other workers, and this difference may partly explain their lower earnings. Of course, we can control for these differences in a regression.

The more serious problem is that individuals in temporary help jobs may differ in unobserved ways from workers in others industries. Insofar as individuals have choices among alternative kinds of jobs, the conscious choice of a temporary help job may select individuals whose opportunities in other jobs are different from observationally identical individuals in those 
jobs. In addition, since job type is partly determined by an employer decision, employer selection on unmeasured characteristics overlays self-selection. Although almost any selection configuration is possible, we suspect that women who have particular difficulty obtaining other employment may obtain temporary help positions, which implies that their low earnings are partly due to unmeasured characteristics.

To address these problems, we fit earnings models separately for our four classes of workers controlling both for individual characteristics and for unmeasured factors that influence selection into the job using the selection correction method proposed by Lee (1982). ${ }^{12}$ In order to identify the selection model we assume that our measures of county employment, county sanction and welfare departure rate, industrial structure and industry-specific earnings enter into the selection equation but not into the equation predicting earnings. ${ }^{13}$ In essence, this implies that these county measures of the economy and welfare policy influence individual earnings exclusively through current employment and observed job type. While this assumption may be violated, these measures have the advantage that they will be largely independent of unmeasured individual characteristics that undoubtedly influence job choice and earnings. They therefore avoid the problems due to self-selection into jobs based on individual-specific earnings opportunities, which we expect to impose the most severe biases on results.

${ }^{12}$ This method uses probabilities obtained in the multinomial logit selection model to construct an inverse Mills ratio that is entered as a control variable ("Lambda" in our tables). The standard errors in these regressions are corrected to account for estimation error in the inverse Mills ratio. See Gyourko and Tracy (1988) for an explication of the method.

${ }^{13}$ The likelihood ratio tests for these measures taken together indicate that in all of our analyses they have a highly significant impact on job choice. 
We chose the above approach rather than a simple instrumental variables model because it is more flexible and allows us to directly incorporate elements of the selection process into the estimation. Individual characteristics are permitted to have differing impacts on ultimate earnings depending on current industry of employment and on whether the individual is employed. In our empirical analyses, the most dramatic differences are between those who are employed and others, and we see below that the impact of taking a temporary help job is substantially different for the kinds of people we observe without a job and those who have a job. The method also uses an explicit selection model to correct estimates of impact, allowing the functional form derived from the selection process to contribute to identification of the model. ${ }^{14}$

Appendix Table A-1 presents equations that predict current earnings for individuals holding jobs in the three classes identified by the multinomial logit: (1) job only in temporary help, (2) job in temporary help and another industry, (3) one or more jobs, but no job in temporary help. Since individuals without jobs have no earnings by definition, they are omitted in this analysis. Results are quite conventional, although, as might be expected in an analysis that controls for type of employment, estimated coefficients are frequently not statistically significant. Perhaps of greatest interest is that the coefficient on Lambda is not statistically significant in any of the regression equations, suggesting that selection effects are not of import in this case.

${ }^{14}$ Lane et al. (forthcoming) use a matching technique to compare temporary help workers to others, which if successful, allows for variation in impact by job choice. However, they report that, in practice, their methods did not match very well on work history measures. Matching assumes unmeasured factors do not bias estimates. 
Appendix Tables A-2 and A-3 present results for selection-corrected models predicting the sum of total inflation-adjusted earnings over the eight quarters subsequent to the reference quarter, as well as earnings in just the eighth quarter. Since individuals with no jobs during the reference quarter may obtain jobs in the following quarters, we include those with no job as an employment class. In all samples, the coefficient on Lambda is statistically significant for those not working during the reference quarter, but it is not significant for the other classes.

Table 7 presents statistics addressing the issue of how job category influences current and subsequent earnings based on these models. Panel A in the table presents estimates of impact on earnings in the current quarter, panel B presents estimates of impact on the sum of earnings over the eight subsequent quarters, and panel C presents estimates of impact on earnings in the eighth quarter. In each case the comparison is between a job in the temporary help industry only and the other three categories of job. Thus, each entry in the table is an estimated difference in earnings due to having a job in the temporary help industry only versus no job (or another job or some combination of jobs).

The simple difference between earnings for those in the given categories is shown in line 1. Line 2 presents impact estimates for an individual whose characteristics are at the mean of those who have no job. As such, it addresses the policy question of how those with no job would fare if they obtained jobs. Line 3 shows the impact estimated at the mean values for individuals in temporary help service jobs. If we view a temporary help job as the treatment, these estimates are the impact of the treatment on the treated. ${ }^{15}$ In lines 2 and 3, estimates of impact are obtained

${ }^{15}$ We also estimated similar measures for those in the other two categories of jobs. Although some differences exist, the pattern of effects are similar, and none of our conclusions would be altered by considering these estimates. 
including Lambda in the estimate (evaluated at the mean for the relevant group), so the estimate is conditional on having made the choice, in effect allowing for unmeasured differences that influence job choice to also impact earnings. It answers the question of what the earnings would be of an individual whose measured characteristics corresponded to this group but who chose one job class or another. If self-selection plays any role, these impact estimates may, in part, reflect unmeasured factors that cause individuals to make different job choices.

In contrast, although lines 4 and 5 are also estimated at the means of group characteristics, the coefficient for Lambda is set to zero. This simulates the experiment of actually taking an individual and placing her into one job category rather than another, as opposed to identifying an individual who makes the choice. Standard errors for these estimates are generally much greater than for comparable estimates in lines 2 and 3. In setting Lambda $=0$, we predict earnings based on independent variable values far from the means for the samples on which coefficient estimates were obtained. Since the coefficient of Lambda is estimated with much error, this causes the predicted earnings based on these equations to contain substantial error. ${ }^{16}$

Comparing the simple differences for current earnings with estimates of impacts reported in lines 2 and 3 in panel A, we see that measured individual characteristics explain only a modest proportion of observed earnings differences between job classes. Estimates of the impact of having a temporary job for an individual who, in fact, has no job (line 2) range from $\$ 629$ to

${ }^{16}$ In general, the most accurately estimated predictions are those where dependent variables are closest to the means on which the sample is estimated. Since the group means on the independent variables that are used in estimating lines 2-3 are only slightly displaced from those used to estimate parameters, estimated standard errors are not inflated by this procedure. 
\$846. However, the second and third columns indicate that for such an individual, earnings in a temporary help job are lower by between $\$ 200$ and $\$ 400$ than they would be in another job, and lower by about $\$ 500$ than earnings for holding both a temporary help and another job. Line 3 shows that impact estimates are generally larger if we focus on those in temporary help jobs. Lines 4 and 5 show similar patterns, although standard errors are so large that comparisons are often not meaningful.

Looking at panel B, we see that individual characteristics become more important when we focus on the sum of earnings over the subsequent eight quarters. Comparing the simple difference in earnings (line 1) with estimates of impact in lines 2 and 3 , we see that the gap in the earnings between those who had no job and those who had a temporary job (column 1) is around $\$ 6000$, but the estimated impact is as little as $\$ 4200$. Estimates reported in columns 4 and 5 display similar patterns.

Perhaps of greatest interest, we see that the dollar decrement to having a temporary help job rather than a job in another industry ranges from about $\$ 500$ to $\$ 1600$, which is generally less than a third of the positive impact of a temporary job relative to no job. Impact estimates for current earnings in panel A implied a much larger relative penalty for temporary help employment. In percentage terms, we find that, controlling for observable characteristics, temporary help employees have current earnings that are about 60 percent of earnings for those in other jobs, but the sum of their subsequent earnings is at least 85 percent of that for other workers. This underscores our observation that the low earnings obtained in temporary help jobs do not appear to be permanent. 
Lines 4 and 5 do not provide much evidence that selection on the basis of unmeasured factors into each job category explains the gap between predicted earnings for temporary help workers and those with no job. In North Carolina, this impact measure is actually larger than those reported in lines 1 and 2 and is statistically significant, whereas in the two Missouri samples, estimates are very imprecise.

Panel C, which presents impact estimates based on earnings in the eighth quarter after the reference quarter, underscores the basic pattern reported in panel B. Earnings for those initially in temporary help jobs are predicted to be at least 94 percent of the earnings they would obtain if they had been in an alternative job. Impact estimates (second column) are generally substantively small and often are not statistically significant. Overall, we conclude that, although temporary help workers earn lower wages initially, they also have faster subsequent wage growth, so that by eight quarters later, workers who initially held temporary help jobs have earnings that are close to those of workers who had jobs in other industries.

Estimates of the impact on ultimate earnings of holding a temporary job rather than no job, as reported in both panels B and C, are substantial both for individuals who don't have jobs (line 1) and for those who have such jobs (line 2), although there generally somewhat higher for the former. It appears that a policy of moving individuals who would not otherwise be employed into temporary help jobs has substantial beneficial effects, whether one is examining current temporary help workers or those who might be subject to future policy.

Perhaps most surprising is the fact that the role of temporary help has changed relatively little in Missouri over the period we observe it. Between 1993 and 1997, the proportion of welfare recipients with any kind of temporary help job more than doubled, and among employed 
welfare recipients, the proportion increased by 50 percent. This period also corresponds with changes in the welfare system, in which there was growing pressure for recipients to seek employment, accompanied by dramatic declines in the welfare caseload. If recipients were being forced into temporary help jobs in this period, we might expect that the those employed in these jobs would fare worse than in earlier years, in contrast to our findings.

\section{Mobility Between Jobs}

Of course, we expect that one of the primary ways that those in temporary help jobs improve their position is by moving into jobs in other industries. Table 8 provides some indication of the job mobility of temporary help workers and others. For ease of presentation, an employed individual is classified by the job from which she received the most earnings in the quarter. We recognize that many of the temporary help workers that "move" to other industries were actually working in firms in those industries while they were employed by temporary help firms. However, for those workers, such a move nonetheless identifies an important change in employment status.

Each row in Table 8 indicates how individuals in a given type of job are distributed across jobs a year later. We see, for example, that in 1993, 38.6 percent of temporary help workers were working in service jobs (including temporary help) one year later. The patterns are quite similar across years and states, and in each case they indicate that mobility from temporary help positions to other industries is substantial. Whereas over 50 percent of workers in service industries (not temporary help) remain in service, only about 40 percent of temporary help workers are still in service one year later. In our two states, the proportion of temporary help workers who have moved to manufacturing, although modest, is greater than for any of the other 
industries, aside from manufacturing itself. Temporary help workers are also relatively likely to move into the "other" category. The likelihood of movement to these two industry categories is significant given that jobs in these industries on average pay higher wages (see Table 3).

While the movements are not striking, they nonetheless give some indication of the kind of mobility that temporary help workers may be experiencing. Furthermore, it is worthwhile to note that the proportion of workers who do not have a job one year later is also similar across industries, suggesting that temporary workers are not significantly more likely to be without a job a year later than those who go to work in other industries.

\section{Movement Off of Welfare}

Next we estimate the probability that an individual is on welfare eight quarters later, controlling for measured characteristics and unmeasured factors that influence selection into the job. We again apply Lee's (1982) selection correction method to this linear probability model. We use the same classification system for job type that we used in the earning models, (i.e., no job, job in temporary help only, job in temporary help and another industry, or job but none in temporary help), and similarly construct the inverse Mills ratio using probabilities obtained in the multinomial logit selection model. Appendix Table A-4 presents results for the selectioncorrected models predicting the probability of leaving welfare eight quarters later, with the standard errors adjusted for estimation error in the inverse Mills ratio.

Appendix Table A-4 shows that the estimated impacts of individual characteristics are consistent with prior research, and differences over time and between states are small. The coefficients on Lambda in all of the Missouri models are generally not statistically significant, 
implying that selection effects are negligible. The North Carolina results suggest, however, that self-selection is particularly important for those with no job during the reference quarter.

Table 9 presents statistics that indicate how the type of job one enters influences the probability of leaving welfare. Differences in the observed probabilities are shown in line 1; lines 2 and 3 show estimated impacts for individuals who initially hold no job and those who hold a temporary help job only. Following the same structure as Table 7, lines 2 and 3 include Lambda, and therefore do not correct for selection on unmeasured factors, whereas lines 4 and 5 set Lambda to zero, removing any differences due to selection on unmeasured characteristics. The results show that welfare recipients holding jobs are substantially more likely to be off of welfare in two years than are those without jobs, but there is a decline in this impact over time. Focusing on Missouri, where we can compare periods prior to and following welfare reform, line 2 shows that, in 1993, the chance of leaving welfare is 6.6 percentage points higher for a recipient with a job (not in temporary help) than for a recipient with no job, whereas in 1997 the difference is only 2.9 percentage points. The difference in North Carolina in 1997 is 3.4 percentage points. Recall that the chance that any individual leaves welfare increases dramatically between 1993 and 1997 (Table 5), and the observed pattern is consistent with the view that welfare reform has had its greatest impact on those without jobs.

In North Carolina, those with only temporary help jobs have a chance of leaving welfare that is 3.8 percentage point lower than those in other jobs. The difference is greater in Missouri, with a difference of nearly 7.7 percentage points in 1993 and over 10 percentage points in 1997. However, when we control for measured personal characteristics (lines 2 and 3), the impact estimates are smaller, less than half as great in some cases, implying that much of the lower 
chance of leaving welfare for temporary help workers is due to measured characteristics. In 1997, in both Missouri and North Carolina, once we control for observable characteristics, recipients working in temporary help jobs are about 3 percentage points less likely to leave welfare in two years than recipients working in other industries. Hence, once measured factors are controlled, working in a temporary help job has only a small impact on the chance of exiting welfare.

Controlling for unmeasured differences that influence selection into jobs (lines 4 and 5) has no consistent effect on the estimated impacts of temporary employment on the chance of leaving welfare. As in the earnings models, these estimates have large standard errors and are not very informative about the importance of selection in biasing estimates of the impact of temporary versus other jobs. However, lines 3 and 4 tend to confirm the positive impact of having a temporary help job rather than no job. In fact, in North Carolina, these are statistically significant and the point estimates imply that a large impact of employment on welfare exit is partly hidden by unmeasured factors.

\section{Summary and Conclusion}

Our results confirm the view that welfare recipients in temporary help jobs receive lower earnings and have less promising prospects for movement from welfare than those who have jobs in other industries. However, what is perhaps of greatest interest is that these differences are small once we control for individual characteristics. Earnings in subsequent years for temporary help workers increase faster than those in other industries. Overall, it is clear that those in 
temporary help jobs have appreciably better future prospects than those who are not holding jobs, even after controlling for all of the characteristics that we can observe.

Whether temporary help jobs are, on net, beneficial to welfare recipients depends on whether they supplant jobs that provide better pay and benefits and greater levels of stability. It seems likely that a welfare recipient with a job in a manufacturing firm faces at least slightly better prospects than a worker in temporary help services. But we suspect that for many welfare recipients, attractive jobs are not available because their skills and observable characteristics make employers unwilling to hire them into the stable and high-paying jobs, such as those in manufacturing. If temporary help jobs provide employment for at least some welfare recipients who would not otherwise have employment, these analyses show that the impact will be strongly positive.

Even if temporary help jobs supplant other jobs, there is very little evidence to suggest that workers in those positions are significantly hurt in the long run. Our analyses suggest that temporary help jobs provide a path to other industries with higher pay and greater stability. There is also evidence that some recipients benefit from being able to combine work in temporary help services with other employment. Undoubtedly, some of those with temporary help jobs find themselves trapped in employment with low earnings and perennial instability, but we do not find evidence that, among welfare recipients, such problems are worse for temporary help workers than for those in most other jobs. Those who take temporary positions are not more likely than those taking jobs in other industries to be without a job a year later. And despite the growth in the number of recipients with temporary help jobs, there is no indication that the circumstances of these workers have deteriorated over time. 


\section{References}

Bartik, Timothy J., "Short-term Employment Persistence for Welfare Recipients: The 'Effects' of Wages, Industry, Occupation, and Firm Size," Working paper, W.E. Upjohn Institute for Employment Research (1997).

Berg, Linnea, Lynn Olson, and Aimee Conrad, "Causes and Implications of Rapid Job Loss Among Participants in a Welfare-to-work Program," Presented at the Annual Research Conference of the Association for Public Policy and Management. Bethesda, MD (1991).

Booth, Alison L., Marco Francesconi, and Jeff Frank, "Temporary Jobs: Stepping Stones or Dead Ends?” Economic Journal 112, (June 2002), F189-213.

Blank, Rebecca M, "Contingent Work in a Changing Labor Market," In Richard B. Freeman and Peter Gottschalk, eds., Generating Jobs: How to Increase Demand for Less-Skilled Workers. New York: Russell Sage Foundation (1998).

Carre, Francoise J., "Temporary Employment in the Eighties." In New Policies for the Part-time and Contingent Workforce, Virginia L. duRivage (ed.). New York: ME Sharpe, (1992) 45-88.

Cohany, Sharon R, "Workers in Alternative Employment Arrangements: A Second Look." Monthly Labor Review 121 (11), (November 1998), 3-21.

Gyourko, Joseph and Joseph Tracy, "An Analysis of Public- and Private-Sector Wages Allowing for Endogenous Choices of Both Government and Union Status." Journal of Labor Economics 6 (2), (April 1998), 229-253.

Heckman, James, Hidehiko Ichimura, Jeffrey Smith and Petra Todd, "Characterizing Selection Bias Using Experimental Data." Econometrica, 66(5) (1998) 1017-1098.

Houseman, Susan N. and Anne E. Polivka "The Implications of Flexible Staffing Arrangements for Job Stability. Working paper, W.E. Upjohn Institute (1999).

Howe, Wayne J., “Temporary Help Workers: Who They Are, What Jobs They Hold.” Monthly Labor Review 109 (11), (November 1986), 45-47.

Hotz, V. Joseph, and John Karl Scholz, "Measuring Employment and Income for Low-Income Populations With Administrative and Survey Data." in Studies of Welfare Populations: Data Collection and Research Issues, National Research Council, National Academy Press (2002), 275-315.

Jorgenson, Helene and Hans Riemer, "Permatemps: Young Temp Workers as Permanent Second Class Employees." American Prospect 11(18), (2000) 38-40.

Kornfeld, Robert and Howard S. Bloom, "Measuring Program Impacts on Earnings and Employment: Do UI Wage Reports from Employers Agree with Surveys of Individuals?" Working paper, Abt Associates and New York University, (1997).

Laird, Karylee and Nicolas Williams, "Employment Growth in the Temporary Help Supply Industry." Journal of Labor Research 17 (4), (Fall 1996) 663-681. 
Lane, Julia, Kelly S. Mikelson, Pat Sharkey, and Doug Wissoker, "Pathways to Work for LowIncome Workers: The Effect of Work in the Temporary Help Industry." Journal of Policy Analysis and Management, (forthcoming).

Lee, Lung-Fei, “Generalized Economietric Models with Selectivity.” Econometrica 51 (2), (March 1982), 507-12.

McAllister, Jean, "Sisyphus at Work in the Warehouse: Temporary Employment in Greenville, South Carolina." In Contingent Work: American Employment Relations in Transition, Kathleen Barker and Kathleen Christensen, eds. Ithaca, NY: Cornell University Press, (1998), 221-242.

Morris, Michael D. and Alexander Vekker, "An Alternative Look at Temporary Workers, Their Choices, and the Growth in Temporary Employment." Journal of Labor Research 22 (2), (Spring 2001), 373-390.

Nollen, Stanley D., "Negative Aspects of Temporary Employment." Journal of Labor Research 17 (4), (Fall 1996), 567-581.

Pavetti, LaDonna and Gregory Acs, Moving Up, Moving Out, or Going Nowhere? A Study of the Employment Patterns of Young Women and the Implications for Welfare Mothers. Journal of Policy Analysis and Management, 20(4), (2001), 721-736.

Pavetti, LaDonna, M. Ihcelle K. Derr, Jacquelyn Anderson, Carole Trippe, and Sidnee Paschal, "The role of intermediaries in linking TANF recipients with jobs." Paper presented at the Federal Reserve Bank of New York, (2000).

Segal, Lewis M. and Daniel G. Sullivan, "The Growth of Temporary Services Work.” Journal of Economic Perspectives 11(2), (Spring 1997a), 117-136.

Segal, Lewis M. and Daniel G. Sullivan, "Temporary Services Employment Durations: Evidence from State UI Data." Federal Reserve Bank of Chicago Working Paper No. WP-97-23, (1997b). 


\begin{tabular}{|c|c|c|c|}
\hline & \multicolumn{2}{|c|}{ Missouri } & \multirow{2}{*}{$\begin{array}{c}\text { North Carolina } \\
1997 \\
\end{array}$} \\
\hline & 1993 & 1997 & \\
\hline \multirow[t]{2}{*}{ Age } & 29.11 & 29.37 & 28.95 \\
\hline & $(7.51)$ & $(7.66)$ & $(7.66)$ \\
\hline \multirow[t]{2}{*}{ Age squared } & 903.77 & 921.06 & 896.90 \\
\hline & $(492.43)$ & $(503.38)$ & $(501.19)$ \\
\hline Percent with education lower than 12 years & 44.8 & 45.7 & 37.8 \\
\hline Percent nonwhite & 46.9 & 51.0 & 69.1 \\
\hline \multirow[t]{2}{*}{ Number of children } & 2.05 & 2.07 & 1.82 \\
\hline & $(1.18)$ & $(1.21)$ & $(1.01)$ \\
\hline \multirow[t]{2}{*}{ Age of the youngest child } & 4.89 & 5.04 & 4.93 \\
\hline & $(4.47)$ & $(4.41)$ & $(4.30)$ \\
\hline Percent on welfare less than 6 months in prior 2 years & 21.6 & 20.2 & 24.6 \\
\hline Percent on welfare $7-12$ months in prior 2 years & 12.9 & 12.9 & 15.1 \\
\hline Percent on welfare $13-23$ months in prior 2 years & 28.6 & 32.4 & 33.3 \\
\hline Percent on welfare 24 months in prior 2 years & 37.0 & 34.6 & 27.0 \\
\hline \multirow[t]{2}{*}{ Percent of previous 8 quarters working } & 27.45 & 37.71 & 43.39 \\
\hline & $(31.40)$ & $(34.00)$ & $(35.16)$ \\
\hline Percent working all of previous 8 qtrs & 4.9 & 8.1 & 11.3 \\
\hline Percent not work in any of previous 8qtrs & 40.8 & 28.1 & 23.1 \\
\hline \multirow[t]{2}{*}{ Total annual earnings in the prior year } & 1397 & 2074 & 2549 \\
\hline & $(2916)$ & $(3463)$ & $(3764)$ \\
\hline \multirow[t]{2}{*}{ Total annual earnings two years prior } & 1785 & 2252 & 2735 \\
\hline & $(3655)$ & (3916) & $(4321)$ \\
\hline Percent in St. Louis County and St. Louis City & 36.4 & 39.1 & n.a. \\
\hline Percent in Kansas City central area (Jackson County) & 16.7 & 17.5 & n.a. \\
\hline Percent in Charlotte central (Mecklenburg County)* & n.a. & n.a. & 11.3 \\
\hline Percent in suburban areas* & 9.7 & 8.4 & 3.5 \\
\hline Percent in small metropolitan areas & 9.5 & 9.0 & 46.9 \\
\hline Percent outside metropolitan areas & 27.8 & 26.0 & 38.4 \\
\hline Quarter 1 & 24.8 & 27.3 & 26.5 \\
\hline Quarter 2 & 24.8 & 25.3 & 25.5 \\
\hline Quarter 3 & 25.2 & 24.3 & 24.8 \\
\hline Quarter 4 & 25.3 & 23.2 & 23.2 \\
\hline Number of observation & 289,160 & 219,442 & 293,276 \\
\hline
\end{tabular}

Note: Standard deviations of continuous variables are in parentheses. Sample includes females aged at least 18 and less than 65 in single parent families, not in child only cases. Sampling frame is quarter by welfare recipient. Earnings are adjusted for inflation to real dollars for the fourth quarter of 1997. *Suburban areas include the noncentral counties in the St. Louis, Kansas City, and Charlott metropolitan areas. 
Table 2: Sample Characteristics of Welfare Recpients by Industry Combinations

\begin{tabular}{|c|c|c|c|c|c|c|c|c|c|}
\hline \multirow[b]{3}{*}{ Variables } & & \multirow[t]{2}{*}{ No Job } & \multicolumn{5}{|c|}{ One Industrial Sector } & \multicolumn{2}{|c|}{ Multiple Sectors } \\
\hline & & & Temp Help & Manufacturing & Retail Trade & Service* & Other & $\begin{array}{c}\text { Temp Help and } \\
\text { Any Other }\end{array}$ & $\begin{array}{c}\text { Any Industry Not } \\
\text { Temp Help }\end{array}$ \\
\hline & & \multicolumn{8}{|c|}{ Panel A. Missouri } \\
\hline \multirow{2}{*}{ Age (mean) } & 1993 & 29.63 & 28.28 & 28.40 & 26.22 & 28.78 & 28.58 & 27.73 & 26.81 \\
\hline & 1997 & 30.10 & 28.74 & 29.65 & 26.79 & 29.22 & 29.08 & 27.92 & 27.47 \\
\hline \multirow{2}{*}{$\begin{array}{l}\text { Percent with education } \\
\text { less than } 12 \text { years }\end{array}$} & 1993 & 47.5 & 35.8 & 43.9 & 41.7 & 36.3 & 30.0 & 31.4 & 36.6 \\
\hline & 1997 & 48.0 & 41.9 & 45.9 & 47.0 & 41.3 & 34.3 & 39.1 & 41.9 \\
\hline \multirow{2}{*}{ Percent nonwhite } & 1993 & 44.7 & 74.8 & 30.9 & 46.6 & 56.2 & 56.5 & 69.2 & 45.6 \\
\hline & 1997 & 45.0 & 73.2 & 34.9 & 50.8 & 63.0 & 63.3 & 71.9 & 54.5 \\
\hline \multirow{2}{*}{ Number of children } & 1993 & $\begin{array}{c}2.10 \\
(1.22)\end{array}$ & $\begin{array}{c}2.02 \\
(1.16)\end{array}$ & $\begin{array}{c}1.88 \\
(1.00)\end{array}$ & $\begin{array}{c}1.81 \\
(1.00)\end{array}$ & $\begin{array}{c}1.97 \\
(1.11)\end{array}$ & $\begin{array}{c}1.88 \\
(1.06)\end{array}$ & $\begin{array}{c}1.88 \\
(1.06)\end{array}$ & $\begin{array}{l}1.78 \\
(.96)\end{array}$ \\
\hline & 1997 & $\begin{array}{c}2.10 \\
(1.25)\end{array}$ & $\begin{array}{c}2.07 \\
(1.19)\end{array}$ & $\begin{array}{c}2.00 \\
(1.11)\end{array}$ & $\begin{array}{c}1.92 \\
(1.11)\end{array}$ & $\begin{array}{c}2.08 \\
(1.19)\end{array}$ & $\begin{array}{c}2.01 \\
(1.15)\end{array}$ & $\begin{array}{c}2.01 \\
(1.14)\end{array}$ & $\begin{array}{c}1.93 \\
(1.09)\end{array}$ \\
\hline \multirow{3}{*}{$\begin{array}{l}\text { Age of youngest child } \\
\text { under } 18\end{array}$} & 1993 & $\begin{array}{c}4.99 \\
(4.53)\end{array}$ & $\begin{array}{c}4.90 \\
(4.40)\end{array}$ & $\begin{array}{c}5.05 \\
(4.45)\end{array}$ & $\begin{array}{c}3.88 \\
(3.91)\end{array}$ & $\begin{array}{c}5.06 \\
(4.42)\end{array}$ & $\begin{array}{c}4.92 \\
(4.32)\end{array}$ & $\begin{array}{c}4.95 \\
(4.40)\end{array}$ & $\begin{array}{c}4.39 \\
(4.13)\end{array}$ \\
\hline & 1997 & 5.13 & 5.08 & 5.33 & 4.27 & 5.26 & 5.15 & 4.88 & 4.70 \\
\hline & & $(4.54)$ & $(4.33)$ & $(4.46)$ & $(3.98)$ & $(4.33)$ & $(4.27)$ & $(4.12)$ & $(4.02)$ \\
\hline \multirow{2}{*}{$\begin{array}{l}\text { Number of months on } \\
\text { welfare in previous } 2 \\
\text { years }\end{array}$} & 1993 & $\begin{array}{l}16.66 \\
(8.56)\end{array}$ & $\begin{array}{l}15.89 \\
(8.46)\end{array}$ & $\begin{array}{l}12.20 \\
(8.99)\end{array}$ & $\begin{array}{l}13.50 \\
(8.88)\end{array}$ & $\begin{array}{l}14.47 \\
(8.72)\end{array}$ & $\begin{array}{l}14.06 \\
(8.72)\end{array}$ & $\begin{array}{l}14.05 \\
(8.64)\end{array}$ & $\begin{array}{l}12.70 \\
(8.73)\end{array}$ \\
\hline & 1997 & $\begin{array}{l}16.60 \\
(8.49) \\
\end{array}$ & $\begin{array}{r}16.36 \\
(8.26) \\
\end{array}$ & $\begin{array}{l}13.15 \\
(8.65) \\
\end{array}$ & $\begin{array}{l}14.85 \\
(8.62) \\
\end{array}$ & $\begin{array}{l}16.13 \\
(8.35) \\
\end{array}$ & $\begin{array}{l}15.83 \\
(8.38) \\
\end{array}$ & $\begin{array}{l}15.23 \\
(8.30) \\
\end{array}$ & $\begin{array}{l}14.20 \\
(8.55) \\
\end{array}$ \\
\hline \multirow{4}{*}{$\begin{array}{l}\text { Percent of previous } 8 \\
\text { quarters employed }\end{array}$} & 1993 & 18.71 & 44.71 & 47.14 & 49.73 & 50.05 & 50.15 & 58.90 & 57.48 \\
\hline & & $(26.00)$ & $(31.06)$ & $(33.47)$ & $(32.62)$ & $(33.17)$ & $(33.04)$ & $(30.68)$ & $(31.56)$ \\
\hline & 1997 & $\begin{array}{c}25.01 \\
(28.94)\end{array}$ & $\begin{array}{c}54.54 \\
(31.62)\end{array}$ & $\begin{array}{c}49.39 \\
(32.88)\end{array}$ & $\begin{array}{c}53.64 \\
(32.08)\end{array}$ & $\begin{array}{c}54.47 \\
(32.83)\end{array}$ & $\begin{array}{c}55.41 \\
(32.98)\end{array}$ & $\begin{array}{c}67.08 \\
(29.63)\end{array}$ & $\begin{array}{c}64.22 \\
(30.40)\end{array}$ \\
\hline & & \multicolumn{8}{|c|}{ Panel B. North Carolina } \\
\hline Age (mean) & 1997 & 29.65 & 27.59 & 28.69 & 26.95 & 29.61 & 29.58 & 27.64 & 27.84 \\
\hline $\begin{array}{l}\text { Percent with education } \\
\text { less than } 12 \text { vears }\end{array}$ & 1997 & 41.6 & 33.8 & 41.2 & 36.2 & 28.8 & 28.9 & 31.4 & 31.9 \\
\hline Percent nonwhite & 1997 & 66.9 & 81.1 & 68.7 & 64.3 & 77.1 & 66.6 & 78.5 & 68.4 \\
\hline Number of children & 1997 & $\begin{array}{c}1.85 \\
(1.04)\end{array}$ & $\begin{array}{l}1.82 \\
(.96)\end{array}$ & $\begin{array}{l}1.85 \\
(.99)\end{array}$ & $\begin{array}{l}1.73 \\
(.94)\end{array}$ & $\begin{array}{c}1.86 \\
(1.00)\end{array}$ & $\begin{array}{l}1.78 \\
(.96)\end{array}$ & $\begin{array}{l}1.79 \\
(.96)\end{array}$ & $\begin{array}{l}1.77 \\
(.95)\end{array}$ \\
\hline $\begin{array}{l}\text { Age of youngest child } \\
\text { under } 18\end{array}$ & 1997 & $\begin{array}{c}4.98 \\
(4.43)\end{array}$ & $\begin{array}{c}4.59 \\
(3.94)\end{array}$ & $\begin{array}{c}5.06 \\
(4.27)\end{array}$ & $\begin{array}{c}4.35 \\
(3.94)\end{array}$ & $\begin{array}{c}5.41 \\
(4.31)\end{array}$ & $\begin{array}{c}5.35 \\
(4.37)\end{array}$ & $\begin{array}{c}4.79 \\
(3.98)\end{array}$ & $\begin{array}{c}4.91 \\
(4.11)\end{array}$ \\
\hline $\begin{array}{l}\text { Number of months on } \\
\text { welfare in previous } 2 \\
\text { years }\end{array}$ & 1997 & $\begin{array}{l}15.47 \\
(8.70)\end{array}$ & $\begin{array}{l}14.26 \\
(8.30)\end{array}$ & $\begin{array}{l}12.34 \\
(8.58)\end{array}$ & $\begin{array}{l}13.92 \\
(8.49)\end{array}$ & $\begin{array}{l}14.73 \\
(8.40)\end{array}$ & $\begin{array}{l}13.63 \\
(8.68)\end{array}$ & $\begin{array}{l}13.00 \\
(8.22)\end{array}$ & $\begin{array}{l}12.88 \\
(8.42)\end{array}$ \\
\hline $\begin{array}{l}\text { Percent of previous } 8 \\
\text { quarters employed }\end{array}$ & 1997 & $\begin{array}{c}28.01 \\
(30.49)\end{array}$ & $\begin{array}{c}57.07 \\
(31.31)\end{array}$ & $\begin{array}{c}60.12 \\
(32.77)\end{array}$ & $\begin{array}{c}58.24 \\
(31.68)\end{array}$ & $\begin{array}{c}59.52 \\
(32.48)\end{array}$ & $\begin{array}{c}57.34 \\
(32.84)\end{array}$ & $\begin{array}{c}70.52 \\
(28.89)\end{array}$ & $\begin{array}{c}68.47 \\
(29.75)\end{array}$ \\
\hline
\end{tabular}

Note: Standard deviations of continuous variables are in parentheses. Sample includes females aged at least 18 and less than 65 in single parent families, not in child

only cases. Sampling frame is quarter by welfare recipient. *Service excludes temporary help. 
Table 3: Distribution of Jobs and Quarterly Earnings by Industry Combinations

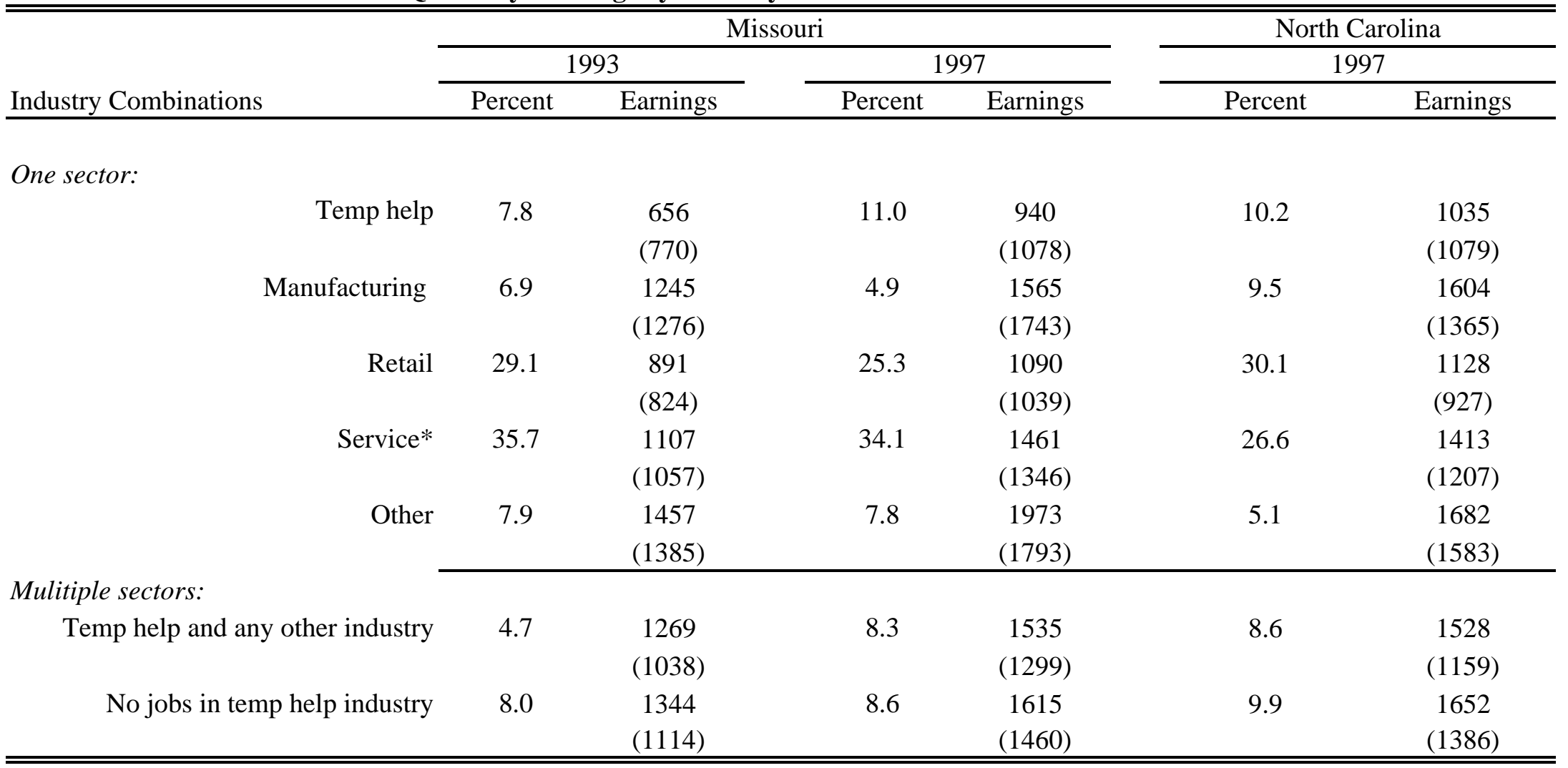

Note: Standard deviations are in parentheses. Sample includes females aged at least 18 and less than 65 in single parent families, not in child only cases. Sampling frame is quarter by welfare recipient. *Service excludes temporary help. 
Table 4: Earnings and Employment Over the Next Two Years by Industry Combinations

\begin{tabular}{|c|c|c|c|c|c|c|}
\hline \multirow[b]{3}{*}{ Industry Combinations } & \multicolumn{4}{|c|}{ Missouri } & \multirow{2}{*}{\multicolumn{2}{|c|}{$\begin{array}{c}\text { North Carolina } \\
1997\end{array}$}} \\
\hline & \multicolumn{2}{|r|}{1993} & \multicolumn{2}{|r|}{1997} & & \\
\hline & $\begin{array}{l}\text { Sum of } \\
\text { Earnings }\end{array}$ & $\begin{array}{l}\text { Number quarters with } \\
\text { Nonzero Earnings }\end{array}$ & $\begin{array}{l}\text { Sum of } \\
\text { Earnings }\end{array}$ & $\begin{array}{c}\text { Number quarters with } \\
\text { Nonzero Earnings }\end{array}$ & $\begin{array}{l}\text { Sum of } \\
\text { Earnings }\end{array}$ & $\begin{array}{c}\text { with Nonzero } \\
\text { Earnings }\end{array}$ \\
\hline \multirow[t]{2}{*}{ No job } & 3450 & 2.1 & 5180 & 2.9 & 7605 & 3.1 \\
\hline & $(6258)$ & $(2.5)$ & $(7600)$ & $(2.7)$ & (8154) & $(2.8)$ \\
\hline \multicolumn{7}{|l|}{ One sector: } \\
\hline Temp help & 9380 & 5.0 & 11600 & 5.5 & 12549 & 5.7 \\
\hline & $(9805)$ & $(2.6)$ & $(10980)$ & $(2.4)$ & $(10695)$ & $(2.4)$ \\
\hline Manufacturing & 11846 & 4.9 & 13391 & 5.3 & 14444 & 5.8 \\
\hline & $(12467)$ & $(2.7)$ & (13016) & $(2.6)$ & $(11421)$ & $(2.4)$ \\
\hline Retail & 9332 & 5.2 & 10705 & 5.5 & 11329 & 5.8 \\
\hline & $(8895)$ & $(2.6)$ & $(9501)$ & $(2.5)$ & (8879) & $(2.4)$ \\
\hline Service* & 11567 & 5.4 & 13798 & 5.8 & 14218 & 6.0 \\
\hline & (11173) & $(2.6)$ & $(11712)$ & $(2.4)$ & (11024) & $(2.4)$ \\
\hline Other & 13752 & 5.4 & 16810 & 5.9 & 15542 & 5.7 \\
\hline & $(12378)$ & $(2.6)$ & $(13831)$ & $(2.4)$ & (13106) & $(2.5)$ \\
\hline \multicolumn{7}{|l|}{ Mulitiple sectors: } \\
\hline \multirow[t]{3}{*}{ Temp help and any other industry } & 13365 & 6.1 & 14779 & 6.3 & 15085 & 6.4 \\
\hline & $(11391)$ & $(2.3)$ & $(11874)$ & $(2.1)$ & $(11296)$ & $(2.0)$ \\
\hline & 12510 & 5.9 & 13981 & 6.2 & 14569 & 6.4 \\
\hline No jobs in Temp help industry & $(10488)$ & $(2.3)$ & $(11436)$ & $(2.1)$ & $(11093)$ & $(2.1)$ \\
\hline
\end{tabular}

Note: Standard deviations are in parentheses. Sample includes females aged at least 18 and less than 65 in single parent families, not in child only cases. Sampling frame is quarter by welfare recipient. *Service excludes temporary help. 
Table 5: Welfare Recipiency Over The Next Two Years by Industry Combinations

\begin{tabular}{|c|c|c|c|c|c|c|c|c|c|}
\hline \multirow[b]{3}{*}{ Industry Combinations } & \multicolumn{6}{|c|}{ Missouri } & \multicolumn{3}{|c|}{ North Carolina } \\
\hline & \multicolumn{3}{|c|}{1993} & \multicolumn{3}{|c|}{1997} & \multicolumn{3}{|c|}{1997} \\
\hline & $\begin{array}{c}\text { Percent on } \\
\text { welfare in } 2 \\
\text { years }\end{array}$ & $\begin{array}{c}\text { Number of } \\
\text { quarters on } \\
\text { welfare next } 2 \\
\text { years }\end{array}$ & $\begin{array}{c}\text { Number of } \\
\text { obs. }\end{array}$ & $\begin{array}{c}\text { Percent on } \\
\text { welfare in } 2 \\
\text { years }\end{array}$ & $\begin{array}{c}\text { Number of } \\
\text { quarters on } \\
\text { welfare next } 2 \\
\text { years }\end{array}$ & $\begin{array}{c}\text { Number of } \\
\text { obs. }\end{array}$ & $\begin{array}{c}\text { Percent on } \\
\text { welfare in } 2 \\
\text { years }\end{array}$ & $\begin{array}{c}\text { Number of } \\
\text { quarters on } \\
\text { welfare next } \\
2 \text { years }\end{array}$ & $\begin{array}{c}\text { Number of } \\
\text { obs. }\end{array}$ \\
\hline \multirow[t]{2}{*}{ No job } & 63.9 & 6.19 & 209,325 & 43.6 & 5.03 & 129,440 & 29.3 & 4.32 & 155,206 \\
\hline & & $(2.54)$ & & & $(2.81)$ & & & $(2.71)$ & \\
\hline \multicolumn{10}{|l|}{ One sector: } \\
\hline \multirow[t]{2}{*}{ Temp help } & 57.3 & 5.65 & 6,230 & 40.6 & 4.51 & 9,921 & 26.3 & 3.67 & 14,088 \\
\hline & & $(2.75)$ & & & (2.89) & & & $(2.71)$ & \\
\hline \multirow[t]{2}{*}{ Manufacturing } & 41.5 & 4.19 & 5,500 & 24.7 & 3.11 & 4,409 & 21.4 & 2.98 & 13,112 \\
\hline & & $(3.02)$ & & & $(2.77)$ & & & $(2.63)$ & \\
\hline \multirow[t]{2}{*}{ Retail } & 51.0 & 5.03 & 23,222 & 36.7 & 4.03 & 22,752 & 24.3 & 3.45 & 41,623 \\
\hline & & $(2.93)$ & & & $(2.93)$ & & & $(2.66)$ & \\
\hline \multirow[t]{2}{*}{ Service* } & 47.1 & 4.75 & 28,503 & 32.7 & 3.76 & 30,710 & 21.6 & 3.16 & 36,706 \\
\hline & & $(3.00)$ & & & $(2.90)$ & & & (2.64) & \\
\hline \multirow[t]{2}{*}{ Other } & 43.6 & 4.41 & 6,290 & 28.8 & 3.45 & 6,993 & 20.5 & 2.98 & 7,073 \\
\hline & & (3.04) & & & $(2.87)$ & & & $(2.70)$ & \\
\hline \multicolumn{10}{|l|}{ Mulitiple sectors: } \\
\hline \multirow{2}{*}{$\begin{array}{r}\text { Temp help and any } \\
\text { other industry }\end{array}$} & 48.7 & 4.92 & 3,744 & 35.4 & 4.03 & 7,485 & 23.8 & 3.30 & 14,088 \\
\hline & & $(2.94)$ & & & $(2.82)$ & & & (2.64) & \\
\hline \multirow{2}{*}{$\begin{array}{r}\text { No jobs in Temp help } \\
\text { industry }\end{array}$} & 43.4 & 4.46 & 6,346 & 31.0 & 3.54 & 7,732 & 22.5 & 3.10 & 13,668 \\
\hline & & $(2.95)$ & & & $(2.83)$ & & & $(2.63)$ & \\
\hline
\end{tabular}

Note: Standard deviations are in parentheses. Sample includes females aged at least 18 and less than 65 in single parent families, not in child only cases. Sampling frame is quarter by welfare recipient. *Service excludes temporary help. 
Table 6: Multinomial Logit Estimation of Occupation Choice

\begin{tabular}{|c|c|c|c|c|c|c|c|c|c|}
\hline & \multicolumn{6}{|c|}{ Missouri } & \multirow{2}{*}{\multicolumn{3}{|c|}{$\begin{array}{c}\text { North Carolina } \\
1997 \\
\end{array}$}} \\
\hline & & 1993 & & & 1997 & & & & \\
\hline & $\begin{array}{c}\text { Job in Temp } \\
\text { Help }\end{array}$ & $\begin{array}{c}\text { Job in Temp } \\
\text { Help and } \\
\text { Other } \\
\text { Industry }\end{array}$ & $\begin{array}{l}\text { Job, but } \\
\text { None in } \\
\text { Temp Help }\end{array}$ & $\begin{array}{c}\text { Job in Temp } \\
\text { Help }\end{array}$ & $\begin{array}{c}\text { Job in Temp } \\
\text { Help and } \\
\text { Other } \\
\text { Industry }\end{array}$ & $\begin{array}{l}\text { Job, but } \\
\text { None in } \\
\text { Temp Help }\end{array}$ & $\begin{array}{l}\text { Job in Temp } \\
\text { Help }\end{array}$ & $\begin{array}{c}\text { Job in Temp } \\
\text { Help and } \\
\text { Other } \\
\text { Industry }\end{array}$ & $\begin{array}{c}\text { Job, but } \\
\text { None in } \\
\text { Temp Help }\end{array}$ \\
\hline Constant & $\begin{array}{l}-11.984 \\
(0.935)\end{array}$ & $\begin{array}{l}-11.862 \\
(1.037)\end{array}$ & $\begin{array}{l}-2.484 \\
(0.216)\end{array}$ & $\begin{array}{l}-7.510 \\
(0.544)\end{array}$ & $\begin{array}{l}-9.204 \\
(0.587)\end{array}$ & $\begin{array}{l}-1.813 \\
(0.204)\end{array}$ & $\begin{array}{l}-6.144 \\
(0.396)\end{array}$ & $\begin{array}{l}-7.454 \\
(0.468)\end{array}$ & $\begin{array}{l}-1.572 \\
(0.183)\end{array}$ \\
\hline Age & $\begin{array}{c}0.129 \\
(0.021)\end{array}$ & $\begin{array}{c}0.037 \\
(0.025)\end{array}$ & $\begin{array}{l}-0.026 \\
(0.007)\end{array}$ & $\begin{array}{c}0.102 \\
(0.014)\end{array}$ & $\begin{array}{c}0.070 \\
(0.018)\end{array}$ & $\begin{array}{l}-0.005 \\
(0.007)\end{array}$ & $\begin{array}{c}0.075 \\
(0.014)\end{array}$ & $\begin{array}{c}0.052 \\
(0.016)\end{array}$ & $\begin{array}{c}0.014 \\
(0.006)\end{array}$ \\
\hline Age square $* 100$ & $\begin{array}{l}-0.236 \\
(0.033)\end{array}$ & $\begin{array}{l}-0.129 \\
(0.039)\end{array}$ & $\begin{array}{l}-0.004 \\
(0.010)\end{array}$ & $\begin{array}{l}-0.175 \\
(0.022)\end{array}$ & $\begin{array}{l}-0.155 \\
(0.028)\end{array}$ & $\begin{array}{l}-0.027 \\
(0.010)\end{array}$ & $\begin{array}{l}-0.162 \\
(0.023)\end{array}$ & $\begin{array}{l}-0.129 \\
(0.025)\end{array}$ & $\begin{array}{c}0.000 \\
(0.000)\end{array}$ \\
\hline $\begin{array}{l}\text { Education lower than } 12 \\
\text { years }\end{array}$ & $\begin{array}{l}-0.220 \\
(0.036)\end{array}$ & $\begin{array}{l}-0.306 \\
(0.044)\end{array}$ & $\begin{array}{l}-0.129 \\
(0.013)\end{array}$ & $\begin{array}{l}-0.142 \\
(0.028)\end{array}$ & $\begin{array}{l}-0.205 \\
(0.031)\end{array}$ & $\begin{array}{l}-0.116 \\
(0.013)\end{array}$ & $\begin{array}{l}-0.166 \\
(0.026)\end{array}$ & $\begin{array}{l}-0.202 \\
(0.027)\end{array}$ & $\begin{array}{l}-0.143 \\
(0.013)\end{array}$ \\
\hline Nonwhite & $\begin{array}{c}0.912 \\
(0.048)\end{array}$ & $\begin{array}{c}0.714 \\
(0.056)\end{array}$ & $\begin{array}{c}0.167 \\
(0.017)\end{array}$ & $\begin{array}{c}0.825 \\
(0.038)\end{array}$ & $\begin{array}{c}0.739 \\
(0.042)\end{array}$ & $\begin{array}{c}0.170 \\
(0.018)\end{array}$ & $\begin{array}{c}0.695 \\
(0.032)\end{array}$ & $\begin{array}{c}0.532 \\
(0.033)\end{array}$ & $\begin{array}{l}0.026 \\
(0.014)\end{array}$ \\
\hline Number of children & $\begin{array}{c}0.003 \\
(0.017)\end{array}$ & $\begin{array}{c}0.002 \\
(0.021)\end{array}$ & $\begin{array}{l}-0.013 \\
(0.006)\end{array}$ & $\begin{array}{l}-0.007 \\
(0.013)\end{array}$ & $\begin{array}{c}0.028 \\
(0.014)\end{array}$ & $\begin{array}{c}0.017 \\
(0.006)\end{array}$ & $\begin{array}{c}0.008 \\
(0.013)\end{array}$ & $\begin{array}{c}0.012 \\
(0.014)\end{array}$ & $\begin{array}{c}0.023 \\
(0.007)\end{array}$ \\
\hline Age of the youngest child & $\begin{array}{c}0.037 \\
(0.005)\end{array}$ & $\begin{array}{c}0.061 \\
(0.006)\end{array}$ & $\begin{array}{c}0.022 \\
(0.002)\end{array}$ & $\begin{array}{c}0.020 \\
(0.004)\end{array}$ & $\begin{array}{c}0.027 \\
(0.005)\end{array}$ & $\begin{array}{c}0.021 \\
(0.002)\end{array}$ & $\begin{array}{c}0.008 \\
(0.004)\end{array}$ & $\begin{array}{c}0.016 \\
(0.004)\end{array}$ & $\begin{array}{c}0.014 \\
(0.002)\end{array}$ \\
\hline $\begin{array}{l}\text { On welfare } 7-12 \text { months in } \\
\text { prior } 2 \text { years }\end{array}$ & $\begin{array}{c}0.044 \\
(0.050)\end{array}$ & $\begin{array}{c}0.167 \\
(0.058)\end{array}$ & $\begin{array}{c}0.110 \\
(0.019)\end{array}$ & $\begin{array}{c}0.045 \\
(0.042)\end{array}$ & $\begin{array}{l}0.105 \\
(0.046)\end{array}$ & $\begin{array}{c}0.115 \\
(0.020)\end{array}$ & $\begin{array}{c}0.052 \\
(0.037)\end{array}$ & $\begin{array}{c}0.127 \\
(0.038)\end{array}$ & $\begin{array}{l}0.040 \\
(0.019)\end{array}$ \\
\hline $\begin{array}{l}\text { On welfare } 13-23 \text { months } \\
\text { in prior } 2 \text { years }\end{array}$ & $\begin{array}{c}0.037 \\
(0.047)\end{array}$ & $\begin{array}{c}0.139 \\
(0.056)\end{array}$ & $\begin{array}{c}0.102 \\
(0.018)\end{array}$ & $\begin{array}{c}0.067 \\
(0.039)\end{array}$ & $\begin{array}{c}0.142 \\
(0.042)\end{array}$ & $\begin{array}{c}0.114 \\
(0.018)\end{array}$ & $\begin{array}{c}0.062 \\
(0.033)\end{array}$ & $\begin{array}{c}0.074 \\
(0.037)\end{array}$ & $\begin{array}{c}0.012 \\
(0.017)\end{array}$ \\
\hline $\begin{array}{l}\text { On welfare } 24 \text { months in } \\
\text { prior } 2 \text { years }\end{array}$ & $\begin{array}{l}-0.021 \\
(0.053)\end{array}$ & $\begin{array}{l}-0.028 \\
(0.067)\end{array}$ & $\begin{array}{c}0.056 \\
(0.020)\end{array}$ & $\begin{array}{c}0.059 \\
(0.043)\end{array}$ & $\begin{array}{c}0.011 \\
(0.049)\end{array}$ & $\begin{array}{c}0.169 \\
(0.021)\end{array}$ & $\begin{array}{c}0.000 \\
(0.040)\end{array}$ & $\begin{array}{l}-0.048 \\
(0.045)\end{array}$ & $\begin{array}{c}0.113 \\
(0.019)\end{array}$ \\
\hline $\begin{array}{l}\text { Percent of previous } 8 \\
\text { quarters working }\end{array}$ & $\begin{array}{c}2.014 \\
(0.097)\end{array}$ & $\begin{array}{c}2.741 \\
(0.104)\end{array}$ & $\begin{array}{c}1.870 \\
(0.038)\end{array}$ & $\begin{array}{c}2.034 \\
(0.073)\end{array}$ & $\begin{array}{l}2.835 \\
(0.080)\end{array}$ & $\begin{array}{c}1.600 \\
(0.037)\end{array}$ & $\begin{array}{c}1.501 \\
(0.064)\end{array}$ & $\begin{array}{c}2.596 \\
(0.072)\end{array}$ & $\begin{array}{l}1.732 \\
(0.035)\end{array}$ \\
\hline $\begin{array}{l}\text { Working all of previous } 8 \\
\text { qtrs }\end{array}$ & $\begin{array}{c}0.027 \\
(0.078)\end{array}$ & $\begin{array}{c}0.159 \\
(0.070)\end{array}$ & $\begin{array}{c}0.411 \\
(0.030)\end{array}$ & $\begin{array}{c}0.205 \\
(0.052)\end{array}$ & $\begin{array}{c}0.371 \\
(0.049)\end{array}$ & $\begin{array}{c}0.366 \\
(0.028)\end{array}$ & $\begin{array}{c}0.164 \\
(0.044)\end{array}$ & $\begin{array}{c}0.401 \\
(0.041)\end{array}$ & $\begin{array}{c}0.421 \\
(0.025)\end{array}$ \\
\hline $\begin{array}{l}\text { No work in any of previous } \\
8 \text { quarters }\end{array}$ & $\begin{array}{l}-1.081 \\
(0.049)\end{array}$ & $\begin{array}{l}-1.329 \\
(0.086)\end{array}$ & $\begin{array}{l}-1.096 \\
(0.018)\end{array}$ & $\begin{array}{l}-0.888 \\
(0.046)\end{array}$ & $\begin{array}{l}-1.146 \\
(0.076)\end{array}$ & $\begin{array}{l}-0.909 \\
(0.019)\end{array}$ & $\begin{array}{l}-1.105 \\
(0.044)\end{array}$ & $\begin{array}{l}-1.301 \\
(0.078)\end{array}$ & $\begin{array}{l}-1.088 \\
(0.019)\end{array}$ \\
\hline $\begin{array}{l}\text { Total annual earnings in } \\
\text { the prior year *1000 }\end{array}$ & $\begin{array}{c}0.069 \\
(0.007)\end{array}$ & $\begin{array}{c}0.138 \\
(0.007)\end{array}$ & $\begin{array}{c}0.164 \\
(0.003)\end{array}$ & $\begin{array}{c}0.073 \\
(0.005)\end{array}$ & $\begin{array}{c}0.142 \\
(0.005)\end{array}$ & $\begin{array}{c}0.162 \\
(0.003)\end{array}$ & $\begin{array}{c}0.122 \\
(0.005)\end{array}$ & $\begin{array}{l}0.168 \\
(0.005)\end{array}$ & $\begin{array}{c}0.164 \\
(0.003)\end{array}$ \\
\hline $\begin{array}{l}\text { Total annual earnings two } \\
\text { years prior } * 1000\end{array}$ & $\begin{array}{l}-0.093 \\
(0.007)\end{array}$ & $\begin{array}{l}-0.097 \\
(0.007)\end{array}$ & $\begin{array}{l}-0.105 \\
(0.003)\end{array}$ & $\begin{array}{l}-0.070 \\
(0.005)\end{array}$ & $\begin{array}{l}-0.099 \\
(0.005)\end{array}$ & $\begin{array}{l}-0.084 \\
(0.002)\end{array}$ & $\begin{array}{l}-0.056 \\
(0.004)\end{array}$ & $\begin{array}{l}-0.084 \\
(0.004)\end{array}$ & $\begin{array}{l}-0.091 \\
(0.002)\end{array}$ \\
\hline St. Louis central & $\begin{array}{c}0.791 \\
(0.261)\end{array}$ & $\begin{array}{c}0.725 \\
(0.311)\end{array}$ & $\begin{array}{l}-0.240 \\
(0.067)\end{array}$ & $\begin{array}{c}0.878 \\
(0.213)\end{array}$ & $\begin{array}{l}-0.115 \\
(0.233)\end{array}$ & $\begin{array}{l}-0.316 \\
(0.081)\end{array}$ & na & na & na \\
\hline Kansas City central & $\begin{array}{c}0.642 \\
(0.309)\end{array}$ & $\begin{array}{c}0.565 \\
(0.350)\end{array}$ & $\begin{array}{l}-0.306 \\
(0.073)\end{array}$ & $\begin{array}{c}1.271 \\
(0.207)\end{array}$ & $\begin{array}{l}0.375 \\
(0.227)\end{array}$ & $\begin{array}{l}-0.278 \\
(0.077)\end{array}$ & na & na & na \\
\hline Charlotte central & & & & & & & $\begin{array}{c}0.061 \\
(0.086)\end{array}$ & $\begin{array}{c}0.437 \\
(0.089)\end{array}$ & $\begin{array}{c}0.173 \\
(0.045)\end{array}$ \\
\hline Suburban metro & $\begin{array}{c}0.953 \\
(0.132)\end{array}$ & $\begin{array}{c}1.274 \\
(0.141)\end{array}$ & $\begin{array}{l}-0.178 \\
(0.035)\end{array}$ & $\begin{array}{c}0.662 \\
(0.087)\end{array}$ & $\begin{array}{c}0.421 \\
(0.103)\end{array}$ & $\begin{array}{l}-0.192 \\
(0.035)\end{array}$ & $\begin{array}{l}-0.054 \\
(0.090)\end{array}$ & $\begin{array}{c}0.321 \\
(0.089)\end{array}$ & $\begin{array}{c}0.219 \\
(0.041)\end{array}$ \\
\hline Small metro & $\begin{array}{c}0.331 \\
(0.140)\end{array}$ & $\begin{array}{c}0.508 \\
(0.172)\end{array}$ & $\begin{array}{l}-0.148 \\
(0.035)\end{array}$ & $\begin{array}{c}0.727 \\
(0.097)\end{array}$ & $\begin{array}{c}0.618 \\
(0.101)\end{array}$ & $\begin{array}{l}-0.045 \\
(0.038)\end{array}$ & $\begin{array}{l}-0.103 \\
(0.042)\end{array}$ & $\begin{array}{l}-0.017 \\
(0.046)\end{array}$ & $\begin{array}{c}0.084 \\
(0.021)\end{array}$ \\
\hline Quarter 2 & $\begin{array}{c}0.073 \\
(0.060)\end{array}$ & $\begin{array}{c}0.243 \\
(0.079)\end{array}$ & $\begin{array}{c}0.249 \\
(0.018)\end{array}$ & $\begin{array}{c}0.422 \\
(0.056)\end{array}$ & $\begin{array}{c}0.609 \\
(0.063)\end{array}$ & $\begin{array}{c}0.216 \\
(0.022)\end{array}$ & $\begin{array}{c}0.207 \\
(0.031)\end{array}$ & $\begin{array}{c}0.432 \\
(0.037)\end{array}$ & $\begin{array}{l}0.154 \\
(0.014)\end{array}$ \\
\hline Quarter 3 & $\begin{array}{c}0.271 \\
(0.059)\end{array}$ & $\begin{array}{c}0.670 \\
(0.075)\end{array}$ & $\begin{array}{c}0.367 \\
(0.018)\end{array}$ & $\begin{array}{c}0.548 \\
(0.055)\end{array}$ & $\begin{array}{l}0.818 \\
(0.060)\end{array}$ & $\begin{array}{c}0.328 \\
(0.021)\end{array}$ & $\begin{array}{c}0.391 \\
(0.039)\end{array}$ & $\begin{array}{c}0.591 \\
(0.044)\end{array}$ & $\begin{array}{c}0.189 \\
(0.018)\end{array}$ \\
\hline Quarter 4 & $\begin{array}{c}0.424 \\
(0.113)\end{array}$ & $\begin{array}{l}0.876 \\
(0.137)\end{array}$ & $\begin{array}{c}0.362 \\
(0.031)\end{array}$ & $\begin{array}{c}0.473 \\
(0.078)\end{array}$ & $\begin{array}{l}0.792 \\
(0.084)\end{array}$ & $\begin{array}{c}0.220 \\
(0.031)\end{array}$ & $\begin{array}{c}0.231 \\
(0.059)\end{array}$ & $\begin{array}{c}0.356 \\
(0.069)\end{array}$ & $\begin{array}{l}-0.062 \\
(0.028)\end{array}$ \\
\hline Sanction rate in county* & n.a. & n.a. & n.a. & $\begin{array}{l}-0.022 \\
(0.005)\end{array}$ & $\begin{array}{l}-0.030 \\
(0.006)\end{array}$ & $\begin{array}{l}-0.001 \\
(0.002)\end{array}$ & $\begin{array}{l}-0.095 \\
(0.635)\end{array}$ & $\begin{array}{l}-0.741 \\
(0.688)\end{array}$ & $\begin{array}{c}0.195 \\
(0.302)\end{array}$ \\
\hline $\begin{array}{l}\text { Welfare Departure rate in } \\
\text { county }\end{array}$ & $\begin{array}{c}0.035 \\
(0.013)\end{array}$ & $\begin{array}{c}0.054 \\
(0.016)\end{array}$ & $\begin{array}{c}0.032 \\
(0.003)\end{array}$ & $\begin{array}{c}0.013 \\
(0.005)\end{array}$ & $\begin{array}{c}0.012 \\
(0.006)\end{array}$ & $\begin{array}{c}0.017 \\
(0.002)\end{array}$ & $\begin{array}{c}0.937 \\
(0.357)\end{array}$ & $\begin{array}{c}3.823 \\
(0.376)\end{array}$ & $\begin{array}{l}2.211 \\
(0.166)\end{array}$ \\
\hline $\begin{array}{l}\text { Log of total employment in } \\
\text { county }\end{array}$ & $\begin{array}{l}0.181 \\
(0.074)\end{array}$ & $\begin{array}{c}0.290 \\
(0.097)\end{array}$ & $\begin{array}{c}0.041 \\
(0.019)\end{array}$ & $\begin{array}{c}0.014 \\
(0.051)\end{array}$ & $\begin{array}{c}0.096 \\
(0.057)\end{array}$ & $\begin{array}{l}-0.005 \\
(0.019)\end{array}$ & $\begin{array}{c}0.218 \\
(0.045)\end{array}$ & $\begin{array}{c}0.109 \\
(0.053)\end{array}$ & $\begin{array}{l}-0.070 \\
(0.021)\end{array}$ \\
\hline
\end{tabular}


Table 6: Continued

\begin{tabular}{|c|c|c|c|c|c|c|c|c|c|}
\hline & \multicolumn{6}{|c|}{ Missouri } & \multirow{2}{*}{\multicolumn{3}{|c|}{$\begin{array}{c}\text { North Carolina } \\
1997 \\
\end{array}$}} \\
\hline & \multicolumn{3}{|c|}{1993} & \multicolumn{3}{|c|}{1997} & & & \\
\hline & $\begin{array}{c}\text { Job in Temp } \\
\text { Help }\end{array}$ & $\begin{array}{l}\text { Job in Temp } \\
\text { Help and } \\
\text { Other } \\
\text { Industry }\end{array}$ & $\begin{array}{c}\text { Job, but } \\
\text { none in } \\
\text { Temp Help }\end{array}$ & $\begin{array}{c}\text { Job in Temp } \\
\text { Help }\end{array}$ & $\begin{array}{l}\text { Job in Temp } \\
\text { Help and } \\
\text { Other } \\
\text { Industry }\end{array}$ & $\begin{array}{c}\text { Job, but none } \\
\text { in Temp } \\
\text { Help }\end{array}$ & $\begin{array}{c}\text { Job in Temp } \\
\text { Help }\end{array}$ & $\begin{array}{c}\text { Job in Temp } \\
\text { Help and } \\
\text { Other } \\
\text { Industry }\end{array}$ & $\begin{array}{c}\text { Job, but } \\
\text { none in } \\
\text { Temp Help }\end{array}$ \\
\hline \multicolumn{10}{|c|}{ Employment Share by Major Industry Sector (Omitted Industry: Service) } \\
\hline $\begin{array}{l}\text { Agriculture, Forestry and } \\
\text { Fishing }\end{array}$ & $\begin{array}{l}-5.466 \\
(3.276)\end{array}$ & $\begin{array}{l}-0.846 \\
(2.596)\end{array}$ & $\begin{array}{c}0.026 \\
(0.477)\end{array}$ & $\begin{array}{l}-0.284 \\
(1.531)\end{array}$ & $\begin{array}{c}2.343 \\
(1.134)\end{array}$ & $\begin{array}{l}-0.045 \\
(0.409)\end{array}$ & $\begin{array}{l}-7.580 \\
(0.819)\end{array}$ & $\begin{array}{l}-5.898 \\
(0.875)\end{array}$ & $\begin{array}{l}-0.010 \\
(0.345)\end{array}$ \\
\hline Mining & $\begin{array}{c}1.818 \\
(4.447)\end{array}$ & $\begin{array}{l}-2.382 \\
(4.413)\end{array}$ & $\begin{array}{l}-0.104 \\
(0.749)\end{array}$ & $\begin{array}{c}7.626 \\
(1.674)\end{array}$ & $\begin{array}{c}7.696 \\
(1.975)\end{array}$ & $\begin{array}{l}-1.168 \\
(0.799)\end{array}$ & $\begin{array}{l}-17.743 \\
(9.952)\end{array}$ & $\begin{array}{l}-25.101 \\
(11.073)\end{array}$ & $\begin{array}{l}-16.016 \\
(4.717)\end{array}$ \\
\hline Construction & $\begin{array}{l}12.443 \\
(1.952)\end{array}$ & $\begin{array}{c}6.717 \\
(2.480)\end{array}$ & $\begin{array}{c}1.039 \\
(0.554)\end{array}$ & $\begin{array}{c}3.873 \\
(1.417)\end{array}$ & $\begin{array}{c}7.352 \\
(1.504)\end{array}$ & $\begin{array}{l}-0.260 \\
(0.539)\end{array}$ & $\begin{array}{c}8.894 \\
(1.236)\end{array}$ & $\begin{array}{c}8.956 \\
(1.381)\end{array}$ & $\begin{array}{c}0.868 \\
(0.597)\end{array}$ \\
\hline Manufacturing & $\begin{array}{c}3.319 \\
(0.725)\end{array}$ & $\begin{array}{c}2.689 \\
(0.848)\end{array}$ & $\begin{array}{c}0.252 \\
(0.158)\end{array}$ & $\begin{array}{c}1.798 \\
(0.351)\end{array}$ & $\begin{array}{c}2.411 \\
(0.392)\end{array}$ & $\begin{array}{l}-0.513 \\
(0.134)\end{array}$ & $\begin{array}{c}1.854 \\
(0.229)\end{array}$ & $\begin{array}{c}2.590 \\
(0.259)\end{array}$ & $\begin{array}{c}0.046 \\
(0.119)\end{array}$ \\
\hline $\begin{array}{l}\text { Transportation, } \\
\text { Communication, etc. }\end{array}$ & $\begin{array}{c}4.165 \\
(1.117)\end{array}$ & $\begin{array}{l}3.176 \\
(1.204)\end{array}$ & $\begin{array}{c}0.128 \\
(0.294)\end{array}$ & $\begin{array}{c}0.787 \\
(0.914)\end{array}$ & $\begin{array}{c}1.863 \\
(0.907)\end{array}$ & $\begin{array}{l}-1.149 \\
(0.348)\end{array}$ & $\begin{array}{l}-2.645 \\
(1.848)\end{array}$ & $\begin{array}{c}3.214 \\
(2.083)\end{array}$ & $\begin{array}{l}-0.139 \\
(0.903)\end{array}$ \\
\hline Wholesale trade & $\begin{array}{c}5.878 \\
(1.710)\end{array}$ & $\begin{array}{c}6.209 \\
(1.949)\end{array}$ & $\begin{array}{l}-0.501 \\
(0.433)\end{array}$ & $\begin{array}{c}1.231 \\
(1.284)\end{array}$ & $\begin{array}{c}1.288 \\
(1.363)\end{array}$ & $\begin{array}{l}-0.960 \\
(0.476)\end{array}$ & $\begin{array}{c}5.681 \\
(1.467)\end{array}$ & $\begin{array}{c}7.199 \\
(1.700)\end{array}$ & $\begin{array}{c}0.720 \\
(0.723)\end{array}$ \\
\hline Retail Trade & $\begin{array}{c}2.417 \\
(1.366)\end{array}$ & $\begin{array}{c}1.844 \\
(1.674)\end{array}$ & $\begin{array}{c}0.895 \\
(0.334)\end{array}$ & $\begin{array}{c}2.970 \\
(0.763)\end{array}$ & $\begin{array}{c}1.556 \\
(0.829)\end{array}$ & $\begin{array}{l}-0.380 \\
(0.287)\end{array}$ & $\begin{array}{l}-3.030 \\
(0.610)\end{array}$ & $\begin{array}{l}-1.095 \\
(0.704)\end{array}$ & $\begin{array}{c}1.360 \\
(0.265)\end{array}$ \\
\hline $\begin{array}{l}\text { Finance, Insurance and } \\
\text { Real Estate }\end{array}$ & $\begin{array}{c}5.238 \\
(3.885)\end{array}$ & $\begin{array}{c}5.382 \\
(4.129)\end{array}$ & $\begin{array}{c}2.830 \\
(0.852)\end{array}$ & $\begin{array}{l}-4.726 \\
(2.541)\end{array}$ & $\begin{array}{c}2.957 \\
(2.907)\end{array}$ & $\begin{array}{c}2.103 \\
(0.872)\end{array}$ & $\begin{array}{l}-10.947 \\
(2.393)\end{array}$ & $\begin{array}{l}-11.813 \\
(2.694)\end{array}$ & $\begin{array}{l}-0.351 \\
(0.900)\end{array}$ \\
\hline \multicolumn{10}{|c|}{ Earnings by Major Industry Sector $(\mathbf{x 1 0 , 0 0 0 )}$} \\
\hline $\begin{array}{l}\text { Agriculture, Forestry and } \\
\text { Fishing }\end{array}$ & $\begin{array}{l}-0.220 \\
(0.556)\end{array}$ & $\begin{array}{l}-0.671 \\
(0.475)\end{array}$ & $\begin{array}{l}-0.171 \\
(0.073)\end{array}$ & $\begin{array}{l}-0.425 \\
(0.236)\end{array}$ & $\begin{array}{l}-0.774 \\
(0.260)\end{array}$ & $\begin{array}{l}-0.064 \\
(0.079)\end{array}$ & $\begin{array}{l}-0.792 \\
(0.168)\end{array}$ & $\begin{array}{r}-0.767 \\
(0.194)\end{array}$ & $\begin{array}{c}0.258 \\
(0.079)\end{array}$ \\
\hline Mining & $\begin{array}{l}-0.013 \\
(0.085)\end{array}$ & $\begin{array}{l}-0.040 \\
(0.123)\end{array}$ & $\begin{array}{l}-0.007 \\
(0.011)\end{array}$ & $\begin{array}{c}0.174 \\
(0.055)\end{array}$ & $\begin{array}{c}0.092 \\
(0.061)\end{array}$ & $\begin{array}{c}0.127 \\
(0.025)\end{array}$ & $\begin{array}{l}-0.151 \\
(0.089)\end{array}$ & $\begin{array}{r}-0.292 \\
(0.097)\end{array}$ & $\begin{array}{c}0.001 \\
(0.046)\end{array}$ \\
\hline Construction & $\begin{array}{l}-0.034 \\
(0.484)\end{array}$ & $\begin{array}{c}0.069 \\
(0.604)\end{array}$ & $\begin{array}{l}-0.168 \\
(0.131)\end{array}$ & $\begin{array}{l}-0.153 \\
(0.301)\end{array}$ & $\begin{array}{c}0.074 \\
(0.318)\end{array}$ & $\begin{array}{c}0.204 \\
(0.105)\end{array}$ & $\begin{array}{c}0.242 \\
(0.206)\end{array}$ & $\begin{array}{r}0.294 \\
(0.245)\end{array}$ & $\begin{array}{c}0.022 \\
(0.094)\end{array}$ \\
\hline Manufacturing & $\begin{array}{c}0.289 \\
(0.366)\end{array}$ & $\begin{array}{l}-1.017 \\
(0.474)\end{array}$ & $\begin{array}{l}-0.161 \\
(0.096)\end{array}$ & $\begin{array}{c}0.440 \\
(0.188)\end{array}$ & $\begin{array}{c}0.363 \\
(0.214)\end{array}$ & $\begin{array}{c}0.299 \\
(0.072)\end{array}$ & $\begin{array}{l}-0.088 \\
(0.120)\end{array}$ & $\begin{array}{r}0.056 \\
(0.132)\end{array}$ & $\begin{array}{c}0.005 \\
(0.058)\end{array}$ \\
\hline $\begin{array}{l}\text { Transportation, } \\
\text { Communication, etc. }\end{array}$ & $\begin{array}{l}-0.064 \\
(0.394)\end{array}$ & $\begin{array}{c}0.147 \\
(0.466)\end{array}$ & $\begin{array}{c}0.053 \\
(0.101)\end{array}$ & $\begin{array}{c}0.507 \\
(0.216)\end{array}$ & $\begin{array}{l}-0.059 \\
(0.233)\end{array}$ & $\begin{array}{c}0.030 \\
(0.087)\end{array}$ & $\begin{array}{l}-0.520 \\
(0.159)\end{array}$ & $\begin{array}{r}-0.780 \\
(0.186)\end{array}$ & $\begin{array}{c}0.153 \\
(0.072)\end{array}$ \\
\hline Wholesale trade & $\begin{array}{l}-1.770 \\
(0.589)\end{array}$ & $\begin{array}{l}-0.628 \\
(0.643)\end{array}$ & $\begin{array}{c}0.344 \\
(0.122)\end{array}$ & $\begin{array}{l}-1.127 \\
(0.306)\end{array}$ & $\begin{array}{l}-0.752 \\
(0.315)\end{array}$ & $\begin{array}{c}0.092 \\
(0.101)\end{array}$ & $\begin{array}{c}0.684 \\
(0.149)\end{array}$ & $\begin{array}{r}0.003 \\
(0.175)\end{array}$ & $\begin{array}{c}0.017 \\
(0.071)\end{array}$ \\
\hline Retail Trade & $\begin{array}{c}0.935 \\
(0.904)\end{array}$ & $\begin{array}{l}-1.569 \\
(1.198)\end{array}$ & $\begin{array}{l}-0.437 \\
(0.281)\end{array}$ & $\begin{array}{l}-0.321 \\
(0.714)\end{array}$ & $\begin{array}{c}1.544 \\
(0.799)\end{array}$ & $\begin{array}{c}0.142 \\
(0.292)\end{array}$ & $\begin{array}{l}-1.089 \\
(0.491)\end{array}$ & $\begin{array}{l}-0.182 \\
(0.479)\end{array}$ & $\begin{array}{l}-0.073 \\
(0.219)\end{array}$ \\
\hline $\begin{array}{l}\text { Finance, Insurance and } \\
\text { Real Estate }\end{array}$ & $\begin{array}{l}-0.522 \\
(0.345)\end{array}$ & $\begin{array}{l}-0.434 \\
(0.423)\end{array}$ & $\begin{array}{c}0.470 \\
(0.107)\end{array}$ & $\begin{array}{c}0.461 \\
(0.193)\end{array}$ & $\begin{array}{c}0.281 \\
(0.229)\end{array}$ & $\begin{array}{c}0.017 \\
(0.076)\end{array}$ & $\begin{array}{l}-0.359 \\
(0.109)\end{array}$ & $\begin{array}{r}0.333 \\
(0.119)\end{array}$ & $\begin{array}{l}-0.112 \\
(0.053)\end{array}$ \\
\hline Service & $\begin{array}{c}2.282 \\
(0.730)\end{array}$ & $\begin{array}{c}2.718 \\
(0.906)\end{array}$ & $\begin{array}{c}0.268 \\
(0.198)\end{array}$ & $\begin{array}{c}0.239 \\
(0.466)\end{array}$ & $\begin{array}{c}0.486 \\
(0.518)\end{array}$ & $\begin{array}{c}0.019 \\
(0.182)\end{array}$ & $\begin{array}{c}0.288 \\
(0.319)\end{array}$ & $\begin{array}{r}0.492 \\
(0.364)\end{array}$ & $\begin{array}{c}0.374 \\
(0.149)\end{array}$ \\
\hline $\mathrm{N}$ & 289,160 & 289,160 & 289,160 & 219,442 & 219,442 & 219,442 & 250,227 & 250,227 & 250,227 \\
\hline
\end{tabular}

Note: Standard errors are in parentheses. Sample includes females aged at least 18 and less than 65 in single parent families, not in child only cases. Sampling frame is quarter by welfare recipient. Estimation takes account of the correlation of errors for recipients who appear in the data multiple times. * In 1993, prior to welfare reform, sanctions were very unusual in Missouri. 
Table 7: Current and Subsequent Predicted Earnings Contingent on Job Choice and Characteristics

\begin{tabular}{|c|c|c|c|c|c|c|c|c|c|}
\hline \multirow[b]{3}{*}{$\begin{array}{l}\text { Group for Which } \\
\text { Impact is Estimated }\end{array}$} & \multicolumn{6}{|c|}{ Missouri } & \multirow{2}{*}{\multicolumn{3}{|c|}{$\begin{array}{c}\text { North Carolina } \\
1997 \\
\end{array}$}} \\
\hline & \multicolumn{3}{|c|}{1993} & \multicolumn{3}{|c|}{1997} & & & \\
\hline & $\begin{array}{c}\text { Temp Help } \\
\text { Only vs. No } \\
\text { Job }\end{array}$ & $\begin{array}{c}\text { Temp } \\
\text { Help Only } \\
\text { vs. Other }\end{array}$ & $\begin{array}{l}\text { Temp Help } \\
\text { Only vs. } \\
\text { Temp Help } \\
\text { and Other }\end{array}$ & $\begin{array}{c}\text { Temp } \\
\text { Help } \\
\text { Only vs. } \\
\text { No Job }\end{array}$ & $\begin{array}{c}\text { Temp Help } \\
\text { Only vs. } \\
\text { Other }\end{array}$ & $\begin{array}{l}\text { Temp Help } \\
\text { Only vs. } \\
\text { Temp Help } \\
\text { and Other }\end{array}$ & $\begin{array}{c}\text { Temp } \\
\text { Help } \\
\text { Only vs. } \\
\text { No Job }\end{array}$ & $\begin{array}{l}\text { Temp } \\
\text { Help } \\
\text { Only vs. } \\
\text { Other }\end{array}$ & $\begin{array}{c}\text { Temp Help } \\
\text { Only vs. } \\
\text { Temp Help } \\
\text { and Other }\end{array}$ \\
\hline \multicolumn{10}{|c|}{ A. Current Quarterly Earnings } \\
\hline 1. No adjustment & $\begin{array}{l}732 \\
(16)\end{array}$ & $\begin{array}{l}-495 \\
(18)\end{array}$ & $\begin{array}{l}-684 \\
(27)\end{array}$ & $\begin{array}{l}945 \\
(17)\end{array}$ & $\begin{array}{l}-480 \\
(19)\end{array}$ & $\begin{array}{l}-598 \\
(26)\end{array}$ & $\begin{array}{l}982 \\
(9)\end{array}$ & $\begin{array}{l}-346 \\
(10)\end{array}$ & $\begin{array}{l}-488 \\
(15)\end{array}$ \\
\hline \multicolumn{10}{|c|}{ Conditional on Job Choice (Lambda=mean for group) } \\
\hline 2. Those with no job & $\begin{array}{l}629 \\
(26)\end{array}$ & $\begin{array}{l}-347 \\
(40)\end{array}$ & $\begin{array}{l}-498 \\
(68)\end{array}$ & $\begin{array}{l}725 \\
(15)\end{array}$ & $\begin{array}{l}-396 \\
(19)\end{array}$ & $\begin{array}{l}-538 \\
(31)\end{array}$ & $\begin{array}{l}846 \\
(14)\end{array}$ & $\begin{array}{l}-238 \\
(16)\end{array}$ & $\begin{array}{l}-429 \\
(30)\end{array}$ \\
\hline 3. Job in temporary help only & $\begin{array}{l}732 \\
(16)\end{array}$ & $\begin{array}{l}-489 \\
(18)\end{array}$ & $\begin{array}{l}-558 \\
(30)\end{array}$ & $\begin{array}{l}945 \\
(17)\end{array}$ & $\begin{array}{l}-457 \\
(19)\end{array}$ & $\begin{array}{l}-492 \\
(25)\end{array}$ & $\begin{array}{l}982 \\
(11)\end{array}$ & $\begin{array}{l}-299 \\
(13)\end{array}$ & $\begin{array}{l}-402 \\
(17)\end{array}$ \\
\hline \multicolumn{10}{|c|}{ Not Conditional on Job Choice $($ Lambda $=0)$} \\
\hline 4. Those with no job & $\begin{array}{c}557 \\
(991)\end{array}$ & $\begin{array}{l}-1075 \\
(3779)\end{array}$ & $\begin{array}{c}-592 \\
(1381)\end{array}$ & $\begin{array}{l}1481 \\
(490)\end{array}$ & $\begin{array}{c}724 \\
(1325)\end{array}$ & $\begin{array}{l}-780 \\
(757)\end{array}$ & $\begin{array}{l}844 \\
(252)\end{array}$ & $\begin{array}{l}-319 \\
(313)\end{array}$ & $\begin{array}{l}-190 \\
(344)\end{array}$ \\
\hline 5. Job in temporary help only & $\begin{array}{c}673 \\
(814)\end{array}$ & $\begin{array}{l}-1013 \\
(2736)\end{array}$ & $\begin{array}{c}-635 \\
(1124)\end{array}$ & $\begin{array}{l}1583 \\
(414)\end{array}$ & $\begin{array}{c}443 \\
(989)\end{array}$ & $\begin{array}{l}-664 \\
(627)\end{array}$ & $\begin{array}{l}980 \\
(223)\end{array}$ & $\begin{array}{l}-356 \\
(257)\end{array}$ & $\begin{array}{l}-205 \\
(294)\end{array}$ \\
\hline \multicolumn{10}{|c|}{ B. Total Earnings in Eight Subsequent Quarters } \\
\hline 1. No adustment & $\begin{array}{l}5930 \\
(210)\end{array}$ & $\begin{array}{l}-1749 \\
(225)\end{array}$ & $\begin{array}{l}-3986 \\
(355)\end{array}$ & $\begin{array}{l}6420 \\
(199)\end{array}$ & $\begin{array}{l}-1513 \\
(213)\end{array}$ & $\begin{array}{l}-3179 \\
(268)\end{array}$ & $\begin{array}{l}6171 \\
(94)\end{array}$ & $\begin{array}{l}-863 \\
(98)\end{array}$ & $\begin{array}{l}-2758 \\
(142)\end{array}$ \\
\hline \multicolumn{10}{|c|}{ Conditional on Job Choice (Lambda=mean for group) } \\
\hline 2. Those with no job & $\begin{array}{l}4359 \\
(302)\end{array}$ & $\begin{array}{l}-1385 \\
(342)\end{array}$ & $\begin{array}{l}-3386 \\
(668)\end{array}$ & $\begin{array}{l}5140 \\
(353)\end{array}$ & $\begin{array}{l}-937 \\
(367)\end{array}$ & $\begin{array}{l}-2324 \\
(617)\end{array}$ & $\begin{array}{c}5992 \\
(3317)\end{array}$ & $\begin{array}{c}542 \\
(3318)\end{array}$ & $\begin{array}{l}-4005 \\
(4443)\end{array}$ \\
\hline 3. Job in temporary help only & $\begin{array}{l}4202 \\
(217)\end{array}$ & $\begin{array}{l}-1595 \\
(231)\end{array}$ & $\begin{array}{l}-2855 \\
(358)\end{array}$ & $\begin{array}{l}4507 \\
(211)\end{array}$ & $\begin{array}{l}-1331 \\
(214)\end{array}$ & $\begin{array}{l}-2278 \\
(293)\end{array}$ & $\begin{array}{l}4249 \\
(163)\end{array}$ & $\begin{array}{l}-501 \\
(163)\end{array}$ & $\begin{array}{c}-1716 \\
(218)\end{array}$ \\
\hline \multicolumn{10}{|c|}{ Not Conditional on Job Choice $($ Lambda $=0)$} \\
\hline 4. Those with no job & $\begin{array}{c}4699 \\
(10472)\end{array}$ & $\begin{array}{c}-5361 \\
(19237)\end{array}$ & $\begin{array}{c}8677 \\
(16707)\end{array}$ & $\begin{array}{c}-241 \\
(10934)\end{array}$ & $\begin{array}{c}-7637 \\
(13151)\end{array}$ & $\begin{array}{l}-14150 \\
(13165)\end{array}$ & $\begin{array}{l}7473 \\
(746)\end{array}$ & $\begin{array}{c}2195 \\
(2059)\end{array}$ & $\begin{array}{r}-1617 \\
(460)\end{array}$ \\
\hline 5. Job in temporary help only & $\begin{array}{c}5823 \\
(8719)\end{array}$ & $\begin{array}{c}-4509 \\
(14469)\end{array}$ & $\begin{array}{c}6972 \\
(13706)\end{array}$ & $\begin{array}{c}1580 \\
(9393)\end{array}$ & $\begin{array}{c}-7036 \\
(10774)\end{array}$ & $\begin{array}{l}-12105 \\
(11075)\end{array}$ & $\begin{array}{c}9189 \\
(3168)\end{array}$ & $\begin{array}{c}2155 \\
(3270)\end{array}$ & $\begin{array}{c}-3640 \\
(3828)\end{array}$ \\
\hline \multicolumn{10}{|c|}{ C. Quarterly Earnings Eight Quarters Later } \\
\hline 1. No adjustment & $\begin{array}{l}779 \\
(38)\end{array}$ & $\begin{array}{l}-86 \\
(40)\end{array}$ & $\begin{array}{c}-438 \\
(65)\end{array}$ & $\begin{array}{l}732 \\
(31)\end{array}$ & $\begin{array}{c}-120 \\
(32)\end{array}$ & $\begin{array}{c}-345 \\
(42)\end{array}$ & $\begin{array}{l}732 \\
(17)\end{array}$ & $\begin{array}{l}-14 \\
(18)\end{array}$ & $\begin{array}{c}-289 \\
(25)\end{array}$ \\
\hline \multicolumn{10}{|c|}{ Conditional on Job Choice (Lambda $=$ mean for group) } \\
\hline 2. Those with no job & $\begin{array}{l}503 \\
(56)\end{array}$ & $\begin{array}{l}-59 \\
(59)\end{array}$ & $\begin{array}{l}-302 \\
(119)\end{array}$ & $\begin{array}{l}514 \\
(44)\end{array}$ & $\begin{array}{l}-66 \\
(46)\end{array}$ & $\begin{array}{c}-132 \\
(80)\end{array}$ & $\begin{array}{l}514 \\
(37)\end{array}$ & $\begin{array}{c}3 \\
(40)\end{array}$ & $\begin{array}{l}-115 \\
(68)\end{array}$ \\
\hline 3. Job in temporary help only & $\begin{array}{l}496 \\
(40)\end{array}$ & $\begin{array}{l}-71 \\
(41)\end{array}$ & $\begin{array}{l}-274 \\
(64)\end{array}$ & $\begin{array}{l}446 \\
(33)\end{array}$ & $\begin{array}{l}-102 \\
(33)\end{array}$ & $\begin{array}{l}-176 \\
(43)\end{array}$ & $\begin{array}{l}446 \\
(27)\end{array}$ & $\begin{array}{c}19 \\
\text { (29) }\end{array}$ & $\begin{array}{l}-124 \\
(35)\end{array}$ \\
\hline \multicolumn{10}{|c|}{ Not Conditional on Job Choice (Lambda $=0$ ) } \\
\hline 4. Those with no job & $\begin{array}{c}854 \\
(2018)\end{array}$ & $\begin{array}{c}-160 \\
(2523)\end{array}$ & $\begin{array}{c}2438 \\
(3011)\end{array}$ & $\begin{array}{c}297 \\
(1115)\end{array}$ & $\begin{array}{c}-588 \\
(1349)\end{array}$ & $\begin{array}{l}-1088 \\
(1547)\end{array}$ & $\begin{array}{l}1120 \\
(551)\end{array}$ & $\begin{array}{c}641 \\
(589)\end{array}$ & $\begin{array}{l}-125 \\
(712)\end{array}$ \\
\hline 5. Job in temporary help only & $\begin{array}{c}1024 \\
(1687)\end{array}$ & $\begin{array}{c}-126 \\
(2003)\end{array}$ & $\begin{array}{c}1962 \\
(2480)\end{array}$ & $\begin{array}{c}618 \\
(962)\end{array}$ & $\begin{array}{c}-552 \\
(1100)\end{array}$ & $\begin{array}{c}-971 \\
(1294)\end{array}$ & $\begin{array}{l}1293 \\
(521)\end{array}$ & $\begin{array}{c}506 \\
(506)\end{array}$ & $\begin{array}{l}-122 \\
(613)\end{array}$ \\
\hline
\end{tabular}

Note: Standard errors are in parentheses. Predicted earnings are based on the regression results reported in Appendix Tables A-1 through A-3. 
Table 8: Movement of Welfare Recipients Between Industries

\begin{tabular}{|c|c|c|c|c|c|c|}
\hline \multirow{3}{*}{$\begin{array}{c}\text { Current Employment } \\
1993 \\
\end{array}$} & \multicolumn{6}{|c|}{ Employment One Year Later } \\
\hline & \multicolumn{6}{|c|}{ Panel A. Missouri } \\
\hline & $\begin{array}{l}\text { Service (incl. } \\
\text { Temp Help) }\end{array}$ & Manufacturing & Retail Trade & Other & No job & Total \\
\hline Temp Help & 38.6 & 5.9 & 10.8 & 9.3 & 35.5 & 100.0 \\
\hline Service, not temp help & 50.3 & 3.5 & 9.1 & 4.5 & 32.7 & 100.0 \\
\hline Manufacturing & 16.8 & 32.4 & 9.7 & 4.2 & 36.9 & 100.0 \\
\hline Retail Trade & 17.7 & 4.0 & 38.0 & 4.8 & 35.5 & 100.0 \\
\hline Other & 18.0 & 4.1 & 9.6 & 38.0 & 30.4 & 100.0 \\
\hline No job & 13.3 & 2.8 & 7.7 & 2.7 & 73.4 & 100.0 \\
\hline \multicolumn{7}{|l|}{1997} \\
\hline Temp help & 42.5 & 5.5 & 11.9 & 10.2 & 29.8 & 100.0 \\
\hline Service, not temp help & 54.7 & 2.6 & 9.9 & 5.2 & 27.7 & 100.0 \\
\hline Manufacturing & 21.8 & 29.7 & 11.5 & 4.6 & 32.4 & 100.0 \\
\hline Retail Trade & 22.5 & 2.9 & 38.0 & 5.4 & 31.3 & 100.0 \\
\hline Other & 23.7 & 3.0 & 9.9 & 38.0 & 25.4 & 100.0 \\
\hline No job & 19.4 & 2.9 & 10.4 & 3.8 & 63.6 & 100.0 \\
\hline 1997 & \multicolumn{6}{|c|}{ Panel B. North Carolina } \\
\hline Temp help & 39.5 & 13.7 & 13.5 & 7.5 & 26.0 & 100.0 \\
\hline Service, not temp help & 58.2 & 4.1 & 10.7 & 4.6 & 22.4 & 100.0 \\
\hline Manufacturing & 19.4 & 41.9 & 10.6 & 3.9 & 24.3 & 100.0 \\
\hline Retail Trade & 19.8 & 5.4 & 44.0 & 4.2 & 26.6 & 100.0 \\
\hline Other & 22.1 & 5.2 & 11.4 & 37.2 & 24.1 & 100.0 \\
\hline No job & 17.6 & 5.0 & 12.3 & 3.2 & 62.0 & 100.0 \\
\hline
\end{tabular}

Note: Industry classification is according to employer paying most earnings in a quarter. 
Table 9: Probability of Leaving Welfare by the Eighth Quarter Contingent on Job Choice and Characteristics

\begin{tabular}{|c|c|c|c|c|c|c|c|c|c|}
\hline \multirow[b]{3}{*}{$\begin{array}{l}\text { Group for Which } \\
\text { Impact is Estimated }\end{array}$} & \multicolumn{6}{|c|}{ Missouri } & \multirow{2}{*}{\multicolumn{3}{|c|}{$\begin{array}{c}\text { North Carolina } \\
1997 \\
\end{array}$}} \\
\hline & \multicolumn{3}{|c|}{1993} & \multicolumn{3}{|c|}{1997} & & & \\
\hline & $\begin{array}{c}\text { Temp Help } \\
\text { Only vs. No } \\
\text { Job }\end{array}$ & $\begin{array}{c}\text { Temp } \\
\text { Help Only } \\
\text { vs. Other }\end{array}$ & $\begin{array}{l}\text { Temp Help } \\
\text { Only vs. } \\
\text { Temp Help } \\
\text { and Other }\end{array}$ & $\begin{array}{c}\text { Temp } \\
\text { Help } \\
\text { Only vs. } \\
\text { No Job } \\
\end{array}$ & $\begin{array}{c}\text { Temp Help } \\
\text { Only vs. } \\
\text { Other }\end{array}$ & $\begin{array}{l}\text { Temp Help } \\
\text { Only vs. } \\
\text { Temp Help } \\
\text { and Other }\end{array}$ & $\begin{array}{c}\text { Temp } \\
\text { Help } \\
\text { Only vs. } \\
\text { No Job }\end{array}$ & $\begin{array}{c}\text { Temp } \\
\text { Help } \\
\text { Only vs. } \\
\text { Other }\end{array}$ & $\begin{array}{l}\text { Temp Help } \\
\text { Only vs. } \\
\text { Temp Help } \\
\text { and Other }\end{array}$ \\
\hline \multicolumn{10}{|c|}{ Dependent Variable: Probability of Leaving Welfare } \\
\hline 1. No adjustment & $\begin{array}{c}0.066 \\
(0.010)\end{array}$ & $\begin{array}{l}-0.100 \\
(0.011)\end{array}$ & $\begin{array}{l}-0.086 \\
(0.014)\end{array}$ & $\begin{array}{c}0.029 \\
(0.008)\end{array}$ & $\begin{array}{l}-0.077 \\
(0.008)\end{array}$ & $\begin{array}{l}-0.053 \\
(0.010)\end{array}$ & $\begin{array}{c}0.034 \\
(0.002)\end{array}$ & $\begin{array}{l}-0.038 \\
(0.002)\end{array}$ & $\begin{array}{l}-0.025 \\
(0.003)\end{array}$ \\
\hline \multicolumn{10}{|c|}{ Conditional on Job Choice (Lambda=mean for group) } \\
\hline 2. Those with no job & $\begin{array}{c}0.114 \\
(0.015)\end{array}$ & $\begin{array}{l}-0.023 \\
(0.015)\end{array}$ & $\begin{array}{l}-0.056 \\
(0.026)\end{array}$ & $\begin{array}{c}0.084 \\
(0.010)\end{array}$ & $\begin{array}{l}-0.027 \\
(0.010)\end{array}$ & $\begin{array}{l}-0.016 \\
(0.017)\end{array}$ & $\begin{array}{c}0.039 \\
(0.009)\end{array}$ & $\begin{array}{l}-0.031 \\
(0.009)\end{array}$ & $\begin{array}{l}-0.047 \\
(0.014)\end{array}$ \\
\hline 3. Job in temporary help only & $\begin{array}{c}0.074 \\
(0.011)\end{array}$ & $\begin{array}{l}-0.036 \\
(0.011)\end{array}$ & $\begin{array}{l}-0.054 \\
(0.015)\end{array}$ & $\begin{array}{c}0.062 \\
(0.008)\end{array}$ & $\begin{array}{l}-0.036 \\
(0.008)\end{array}$ & $\begin{array}{l}-0.032 \\
(0.011)\end{array}$ & $\begin{array}{c}0.031 \\
(0.007)\end{array}$ & $\begin{array}{l}-0.015 \\
(0.007)\end{array}$ & $\begin{array}{l}-0.019 \\
(0.009)\end{array}$ \\
\hline \multicolumn{10}{|c|}{ Not Conditional on Job Choice (Lambda=0) } \\
\hline 4. Those with no job & $\begin{array}{c}0.603 \\
(0.357)\end{array}$ & $\begin{array}{c}0.188 \\
(0.374)\end{array}$ & $\begin{array}{l}-0.045 \\
(0.521)\end{array}$ & $\begin{array}{c}0.022 \\
(0.159)\end{array}$ & $\begin{array}{l}-0.193 \\
(0.163)\end{array}$ & $\begin{array}{l}-0.114 \\
(0.268)\end{array}$ & $\begin{array}{c}0.547 \\
(0.123)\end{array}$ & $\begin{array}{c}0.036 \\
(0.124)\end{array}$ & $\begin{array}{l}-0.095 \\
(0.164)\end{array}$ \\
\hline 5. Job in temporary help only & $\begin{array}{c}0.507 \\
(0.299)\end{array}$ & $\begin{array}{c}0.167 \\
(0.308)\end{array}$ & $\begin{array}{l}-0.040 \\
(0.430)\end{array}$ & $\begin{array}{c}0.041 \\
(0.142)\end{array}$ & $\begin{array}{l}-0.167 \\
(0.137)\end{array}$ & $\begin{array}{l}-0.115 \\
(0.223)\end{array}$ & $\begin{array}{c}0.697 \\
(0.119)\end{array}$ & $\begin{array}{c}0.073 \\
(0.108)\end{array}$ & $\begin{array}{l}-0.046 \\
(0.141)\end{array}$ \\
\hline
\end{tabular}

Note: Standard errors are in parentheses. Impact estimates are based on predicted means using regression results reported in Appendix Table A-4. 
Appendix Table A-1: Estimates for Regression Equations Predicting Current Quarterly Earnings, Controlling for Self-Selection into Job Category

\begin{tabular}{|c|c|c|c|c|c|c|c|c|c|}
\hline & \multicolumn{6}{|c|}{ Missouri } & \multirow{2}{*}{\multicolumn{3}{|c|}{$\begin{array}{c}\text { North Carolina } \\
1997 \\
\end{array}$}} \\
\hline & & 1993 & & & 1997 & & & & \\
\hline & $\begin{array}{c}\text { Job in Temp } \\
\text { Help }\end{array}$ & $\begin{array}{c}\text { Job in Temp } \\
\text { Help and } \\
\text { Other } \\
\text { Industry }\end{array}$ & $\begin{array}{c}\text { Job, but } \\
\text { none in } \\
\text { Temp Help }\end{array}$ & $\begin{array}{c}\text { Job in Temp } \\
\text { Help }\end{array}$ & $\begin{array}{c}\text { Job in Temp } \\
\text { Help and } \\
\text { Other } \\
\text { Industry }\end{array}$ & $\begin{array}{c}\text { Job, but } \\
\text { none in } \\
\text { Temp Help }\end{array}$ & $\begin{array}{c}\text { Job in Temp } \\
\text { Help }\end{array}$ & $\begin{array}{c}\text { Job in Temp } \\
\text { Help and } \\
\text { Other } \\
\text { Industry }\end{array}$ & $\begin{array}{c}\text { Job, but } \\
\text { none in } \\
\text { Temp Help }\end{array}$ \\
\hline Constant & $\begin{array}{c}-212.08 \\
(1389.100)\end{array}$ & $\begin{array}{c}-955.85 \\
(1150.035)\end{array}$ & $\begin{array}{c}296.35 \\
(2518.649)\end{array}$ & $\begin{array}{c}806.45 \\
(730.829)\end{array}$ & $\begin{array}{c}1488.74 \\
(830.088)\end{array}$ & $\begin{array}{c}-205.01 \\
(977.562)\end{array}$ & $\begin{array}{c}194.24 \\
(312.99)\end{array}$ & $\begin{array}{c}612.70 \\
(419.91)\end{array}$ & $\begin{array}{c}474.00 \\
(176.25)\end{array}$ \\
\hline Age & $\begin{array}{c}54.07 \\
(21.958)\end{array}$ & $\begin{array}{c}118.46 \\
(23.617)\end{array}$ & $\begin{array}{c}56.60 \\
(46.844)\end{array}$ & $\begin{array}{c}40.83 \\
(17.007)\end{array}$ & $\begin{array}{c}39.11 \\
(26.076)\end{array}$ & $\begin{array}{c}33.75 \\
(15.009)\end{array}$ & $\begin{array}{c}29.58 \\
(12.55)\end{array}$ & $\begin{array}{c}25.74 \\
(21.76)\end{array}$ & $\begin{array}{l}28.07 \\
(6.60)\end{array}$ \\
\hline Age square $* 100$ & $\begin{array}{c}-71.42 \\
(36.376)\end{array}$ & $\begin{array}{l}-151.85 \\
(38.617)\end{array}$ & $\begin{array}{c}-64.44 \\
(39.059)\end{array}$ & $\begin{array}{c}-47.13 \\
(26.533)\end{array}$ & $\begin{array}{c}-39.59 \\
(44.358)\end{array}$ & $\begin{array}{c}-38.96 \\
(15.448)\end{array}$ & $\begin{array}{c}-31.71 \\
(20.23)\end{array}$ & $\begin{array}{l}-18.22 \\
(35.38)\end{array}$ & $\begin{array}{l}-31.14 \\
(9.20)\end{array}$ \\
\hline Education lower than 12 years & $\begin{array}{l}-129.15 \\
(39.346)\end{array}$ & $\begin{array}{l}-182.41 \\
(50.322)\end{array}$ & $\begin{array}{l}-117.98 \\
(99.494)\end{array}$ & $\begin{array}{l}-164.20 \\
(26.939)\end{array}$ & $\begin{array}{l}-215.09 \\
(33.257)\end{array}$ & $\begin{array}{l}-177.02 \\
(26.680)\end{array}$ & $\begin{array}{l}-150.70 \\
(21.62)\end{array}$ & $\begin{array}{l}-119.17 \\
(24.90)\end{array}$ & $\begin{array}{c}-109.87 \\
(9.83)\end{array}$ \\
\hline Nonwhite & $\begin{array}{c}-83.02 \\
(121.867)\end{array}$ & $\begin{array}{l}-102.90 \\
(93.001)\end{array}$ & $\begin{array}{c}-5.68 \\
(71.534)\end{array}$ & $\begin{array}{c}-66.10 \\
(69.105)\end{array}$ & $\begin{array}{l}-166.97 \\
(78.242)\end{array}$ & $\begin{array}{c}32.60 \\
(17.158)\end{array}$ & $\begin{array}{l}-26.89 \\
(37.61)\end{array}$ & $\begin{array}{l}-14.17 \\
(38.61)\end{array}$ & $\begin{array}{c}-3.59 \\
(11.69)\end{array}$ \\
\hline Number of children & $\begin{array}{c}-31.70 \\
(13.233)\end{array}$ & $\begin{array}{c}-54.76 \\
(24.276)\end{array}$ & $\begin{array}{c}-21.01 \\
(16.637)\end{array}$ & $\begin{array}{c}-55.61 \\
(11.781)\end{array}$ & $\begin{array}{c}-50.55 \\
(16.018)\end{array}$ & $\begin{array}{c}-28.57 \\
(11.327)\end{array}$ & $\begin{array}{l}-11.91 \\
(11.80)\end{array}$ & $\begin{array}{l}-42.60 \\
(14.10)\end{array}$ & $\begin{array}{c}2.75 \\
(5.25)\end{array}$ \\
\hline Age of the youngest child & $\begin{array}{c}-7.78 \\
(7.008)\end{array}$ & $\begin{array}{l}-16.06 \\
(9.687)\end{array}$ & $\begin{array}{c}-6.77 \\
(15.381)\end{array}$ & $\begin{array}{l}-14.98 \\
(5.147)\end{array}$ & $\begin{array}{l}-11.47 \\
(7.664)\end{array}$ & $\begin{array}{c}-6.25 \\
(5.279)\end{array}$ & $\begin{array}{r}-10.31 \\
(4.00)\end{array}$ & $\begin{array}{l}-20.79 \\
(5.21)\end{array}$ & $\begin{array}{l}-7.75 \\
(1.98)\end{array}$ \\
\hline $\begin{array}{l}\text { On welfare } 7-12 \text { months in prior } \\
2 \text { years }\end{array}$ & $\begin{array}{c}176.73 \\
(45.401)\end{array}$ & $\begin{array}{c}151.95 \\
(59.585)\end{array}$ & $\begin{array}{c}222.89 \\
(103.803)\end{array}$ & $\begin{array}{c}191.84 \\
(50.497)\end{array}$ & $\begin{array}{c}266.73 \\
(58.931)\end{array}$ & $\begin{array}{c}302.18 \\
(35.124)\end{array}$ & $\begin{array}{l}107.79 \\
(33.50)\end{array}$ & $\begin{array}{l}117.26 \\
(40.34)\end{array}$ & $\begin{array}{l}190.44 \\
(19.91)\end{array}$ \\
\hline $\begin{array}{l}\text { On welfare } 13-23 \text { months in } \\
\text { prior } 2 \text { years }\end{array}$ & $\begin{array}{c}78.02 \\
(42.065)\end{array}$ & $\begin{array}{c}207.86 \\
(58.210)\end{array}$ & $\begin{array}{c}226.97 \\
(91.814)\end{array}$ & $\begin{array}{c}177.83 \\
(39.400)\end{array}$ & $\begin{array}{c}257.12 \\
(57.684)\end{array}$ & $\begin{array}{c}348.89 \\
(26.472)\end{array}$ & $\begin{array}{l}110.39 \\
(31.03)\end{array}$ & $\begin{array}{c}95.68 \\
(31.51)\end{array}$ & $\begin{array}{l}218.30 \\
(27.78)\end{array}$ \\
\hline $\begin{array}{l}\text { On welfare } 24 \text { months in prior } 2 \\
\text { years }\end{array}$ & $\begin{array}{c}102.29 \\
(50.577)\end{array}$ & $\begin{array}{c}77.67 \\
(73.609)\end{array}$ & $\begin{array}{c}239.14 \\
(80.859)\end{array}$ & $\begin{array}{c}232.72 \\
(47.095)\end{array}$ & $\begin{array}{c}402.36 \\
(61.796)\end{array}$ & $\begin{array}{c}434.78 \\
(47.812)\end{array}$ & $\begin{array}{l}189.65 \\
(37.98)\end{array}$ & $\begin{array}{l}127.98 \\
(41.54)\end{array}$ & $\begin{array}{l}293.42 \\
(39.09)\end{array}$ \\
\hline $\begin{array}{l}\text { Percent of previous } 8 \text { quarters } \\
\text { working }\end{array}$ & $\begin{array}{c}-175.94 \\
(218.724)\end{array}$ & $\begin{array}{c}-410.67 \\
(260.728)\end{array}$ & $\begin{array}{c}-747.92 \\
(1539.021)\end{array}$ & $\begin{array}{c}-570.71 \\
(140.644)\end{array}$ & $\begin{array}{c}-955.31 \\
(242.348)\end{array}$ & $\begin{array}{c}-561.73 \\
(416.377)\end{array}$ & $\begin{array}{l}-303.59 \\
(74.27)\end{array}$ & $\begin{array}{l}-546.20 \\
(100.47)\end{array}$ & $\begin{array}{l}-655.63 \\
(78.74)\end{array}$ \\
\hline Working all of previous 8 qtrs & $\begin{array}{c}35.54 \\
(93.878)\end{array}$ & $\begin{array}{c}-20.24 \\
(87.171)\end{array}$ & $\begin{array}{c}-152.89 \\
(174.785)\end{array}$ & $\begin{array}{c}75.77 \\
(68.015)\end{array}$ & $\begin{array}{l}-101.18 \\
(57.168)\end{array}$ & $\begin{array}{c}-66.59 \\
(27.041)\end{array}$ & $\begin{array}{c}26.31 \\
(43.75)\end{array}$ & $\begin{array}{c}70.87 \\
(38.70)\end{array}$ & $\begin{array}{c}39.06 \\
(21.40)\end{array}$ \\
\hline $\begin{array}{l}\text { No work in any of previous } 8 \\
\text { quarters }\end{array}$ & $\begin{array}{c}-124.79 \\
(142.559)\end{array}$ & $\begin{array}{c}-51.05 \\
(178.011)\end{array}$ & $\begin{array}{c}39.59 \\
(1166.344)\end{array}$ & $\begin{array}{c}-25.76 \\
(68.075)\end{array}$ & $\begin{array}{c}15.73 \\
(98.881)\end{array}$ & $\begin{array}{c}-329.86 \\
(409.613)\end{array}$ & $\begin{array}{l}-105.41 \\
(55.98)\end{array}$ & $\begin{array}{l}-295.66 \\
(77.69)\end{array}$ & $\begin{array}{l}-232.89 \\
(82.64)\end{array}$ \\
\hline $\begin{array}{l}\text { Total annual earnings in the prior } \\
\text { year } * 1000\end{array}$ & $\begin{array}{c}78.59 \\
(12.579)\end{array}$ & $\begin{array}{c}103.10 \\
(13.717)\end{array}$ & $\begin{array}{c}91.26 \\
(147.976)\end{array}$ & $\begin{array}{c}111.10 \\
(12.117)\end{array}$ & $\begin{array}{c}104.39 \\
(13.329)\end{array}$ & $\begin{array}{c}158.87 \\
(56.249)\end{array}$ & $\begin{array}{c}78.03 \\
(7.17)\end{array}$ & $\begin{array}{l}80.30 \\
(6.00)\end{array}$ & $\begin{array}{l}112.53 \\
(13.61)\end{array}$ \\
\hline $\begin{array}{l}\text { Total annual earnings two years } \\
\text { prior } * 1000\end{array}$ & $\begin{array}{c}4.62 \\
(11.331)\end{array}$ & $\begin{array}{c}13.99 \\
(9.988)\end{array}$ & $\begin{array}{c}37.55 \\
(90.822)\end{array}$ & $\begin{array}{c}25.14 \\
(6.937)\end{array}$ & $\begin{array}{c}49.15 \\
(10.884)\end{array}$ & $\begin{array}{c}21.66 \\
(26.388)\end{array}$ & $\begin{array}{c}15.01 \\
(4.51)\end{array}$ & $\begin{array}{l}22.92 \\
(4.78)\end{array}$ & $\begin{array}{l}28.13 \\
(7.07)\end{array}$ \\
\hline St. Louis central & $\begin{array}{c}-78.32 \\
(178.824)\end{array}$ & $\begin{array}{c}229.82 \\
(144.932)\end{array}$ & $\begin{array}{c}289.62 \\
(119.863)\end{array}$ & $\begin{array}{c}61.55 \\
(72.389)\end{array}$ & $\begin{array}{c}223.00 \\
(70.569)\end{array}$ & $\begin{array}{c}344.94 \\
(17.995)\end{array}$ & na & na & na \\
\hline Kansas City central & $\begin{array}{c}-83.95 \\
(186.764)\end{array}$ & $\begin{array}{c}237.81 \\
(174.096)\end{array}$ & $\begin{array}{c}290.05 \\
(35.571)\end{array}$ & $\begin{array}{c}-5.35 \\
(82.325)\end{array}$ & $\begin{array}{c}167.48 \\
(98.468)\end{array}$ & $\begin{array}{c}405.27 \\
(41.181)\end{array}$ & na & na & na \\
\hline Charlotte central & n.a. & n.a. & n.a. & n.a. & n.a. & n.a. & $\begin{array}{c}-5.64 \\
(35.41)\end{array}$ & $\begin{array}{l}106.45 \\
(50.42)\end{array}$ & $\begin{array}{l}116.19 \\
(18.34)\end{array}$ \\
\hline Suburban metro & $\begin{array}{c}-45.95 \\
(201.111)\end{array}$ & $\begin{array}{c}55.86 \\
(179.181)\end{array}$ & $\begin{array}{c}115.71 \\
(106.545)\end{array}$ & $\begin{array}{c}-45.66 \\
(78.270)\end{array}$ & $\begin{array}{c}-76.75 \\
(63.904)\end{array}$ & $\begin{array}{c}129.01 \\
(46.221)\end{array}$ & $\begin{array}{c}20.00 \\
(63.42)\end{array}$ & $\begin{array}{c}49.22 \\
(50.96)\end{array}$ & $\begin{array}{c}40.10 \\
(25.66)\end{array}$ \\
\hline Small metro & $\begin{array}{c}-223.01 \\
(132.894)\end{array}$ & $\begin{array}{c}-9.44 \\
(151.639)\end{array}$ & $\begin{array}{c}38.22 \\
(19.017)\end{array}$ & $\begin{array}{l}-131.09 \\
(56.291)\end{array}$ & $\begin{array}{l}-130.37 \\
(61.107)\end{array}$ & $\begin{array}{c}54.35 \\
(16.343)\end{array}$ & $\begin{array}{c}-4.72 \\
(22.93)\end{array}$ & $\begin{array}{c}16.35 \\
(24.56)\end{array}$ & $\begin{array}{l}47.20 \\
(9.17)\end{array}$ \\
\hline Quarter 2 & $\begin{array}{c}36.92 \\
(32.532)\end{array}$ & $\begin{array}{c}141.93 \\
(52.995)\end{array}$ & $\begin{array}{c}46.93 \\
(187.248)\end{array}$ & $\begin{array}{c}15.78 \\
(28.236)\end{array}$ & $\begin{array}{c}-3.65 \\
(52.658)\end{array}$ & $\begin{array}{c}46.04 \\
(35.956)\end{array}$ & $\begin{array}{l}113.74 \\
(21.34)\end{array}$ & $\begin{array}{l}107.69 \\
(30.27)\end{array}$ & $\begin{array}{c}96.29 \\
(11.08)\end{array}$ \\
\hline Quarter 3 & $\begin{array}{c}46.37 \\
(52.478)\end{array}$ & $\begin{array}{c}168.34 \\
(77.932)\end{array}$ & $\begin{array}{c}22.63 \\
(281.910)\end{array}$ & $\begin{array}{c}8.38 \\
(34.439)\end{array}$ & $\begin{array}{c}-13.61 \\
(55.186)\end{array}$ & $\begin{array}{c}34.28 \\
(64.788)\end{array}$ & $\begin{array}{l}153.86 \\
(24.43)\end{array}$ & $\begin{array}{l}110.47 \\
(34.21)\end{array}$ & $\begin{array}{c}82.96 \\
(11.95)\end{array}$ \\
\hline Quarter 4 & $\begin{array}{c}160.97 \\
(59.922)\end{array}$ & $\begin{array}{c}226.15 \\
(74.127)\end{array}$ & $\begin{array}{c}173.68 \\
(278.074)\end{array}$ & $\begin{array}{c}142.18 \\
(34.225)\end{array}$ & $\begin{array}{c}141.91 \\
(62.336)\end{array}$ & $\begin{array}{c}197.69 \\
(64.582)\end{array}$ & $\begin{array}{l}267.69 \\
(27.74)\end{array}$ & $\begin{array}{l}202.26 \\
(33.90)\end{array}$ & $\begin{array}{l}232.97 \\
(10.39)\end{array}$ \\
\hline Lambda & $\begin{array}{c}26.92 \\
(370.317)\end{array}$ & $\begin{array}{c}-7.43 \\
(315.082)\end{array}$ & $\begin{array}{c}-412.39 \\
(2311.235)\end{array}$ & $\begin{array}{c}-323.09 \\
(210.604)\end{array}$ & $\begin{array}{c}-379.29 \\
(219.524)\end{array}$ & $\begin{array}{c}270.13 \\
(919.819)\end{array}$ & $\begin{array}{c}1.16 \\
(112.01)\end{array}$ & $\begin{array}{c}94.31 \\
(91.38)\end{array}$ & $\begin{array}{c}-61.33 \\
(147.40)\end{array}$ \\
\hline $\mathrm{N}$ & 6,230 & 3,744 & 69,861 & 9,921 & 7,485 & 72,596 & 12,148 & 10,073 & 95,254 \\
\hline
\end{tabular}

of the correlation of errors for recipients who appear in the data multiple times. 
Appendix Table A-2 Estimates for Regression Equations Predicting Total Earnings in Subsequent Eight Quarters, Controlling for Self-Selection into Job Category

\begin{tabular}{|c|c|c|c|c|c|c|c|c|c|c|c|c|}
\hline & \multicolumn{8}{|c|}{ Missouri } & \multirow{2}{*}{\multicolumn{4}{|c|}{$\begin{array}{c}\text { North Carolina } \\
1997\end{array}$}} \\
\hline & \multicolumn{4}{|c|}{1993} & \multicolumn{4}{|c|}{1997} & & & & \\
\hline & \multicolumn{4}{|c|}{ Job in Temp } & \multicolumn{4}{|c|}{ Job in Temp } & \multicolumn{4}{|c|}{ Job in Temp } \\
\hline & No Job & $\begin{array}{c}\text { Job in Temp } \\
\text { Help }\end{array}$ & $\begin{array}{l}\text { Help and } \\
\text { Other } \\
\text { Industry }\end{array}$ & $\begin{array}{l}\text { Job, but none } \\
\text { in Temp Help }\end{array}$ & No Job & $\begin{array}{c}\text { Job in Temp } \\
\text { Help }\end{array}$ & $\begin{array}{l}\text { Help and } \\
\text { Other } \\
\text { Industry }\end{array}$ & $\begin{array}{l}\text { Job, but } \\
\text { none in } \\
\text { Temp Help }\end{array}$ & No Job & $\begin{array}{c}\text { Job in Temp } \\
\text { Help }\end{array}$ & $\begin{array}{l}\text { Help and } \\
\text { Other } \\
\text { Industry }\end{array}$ & $\begin{array}{l}\text { Job, but none } \\
\text { in Temp } \\
\text { Help }\end{array}$ \\
\hline Constant & $\begin{array}{l}2950.014 \\
(524.150)\end{array}$ & $\begin{array}{c}5046.317 \\
(15295.150)\end{array}$ & $\begin{array}{c}-17533.42 \\
(16756.630)\end{array}$ & $\begin{array}{c}4448.406 \\
(11018.960)\end{array}$ & $\begin{array}{l}2385.021 \\
(635.130)\end{array}$ & $\begin{array}{c}-6147.823 \\
(15382.030)\end{array}$ & $\begin{array}{c}13649.09 \\
(12894.480)\end{array}$ & $\begin{array}{c}4162.094 \\
(5924.987)\end{array}$ & $\begin{array}{c}2237.36 \\
(674.461)\end{array}$ & $\begin{array}{c}8004.139 \\
(4695.544)\end{array}$ & $\begin{array}{c}14613.92 \\
(5246.276)\end{array}$ & $\begin{array}{c}3927.033 \\
(2135.080)\end{array}$ \\
\hline Age & $\begin{array}{c}15.01 \\
(25.735)\end{array}$ & $\begin{array}{c}291.11 \\
(298.834)\end{array}$ & $\begin{array}{c}968.61 \\
(342.617)\end{array}$ & $\begin{array}{c}380.32 \\
(239.741)\end{array}$ & $\begin{array}{c}112.08 \\
(33.630)\end{array}$ & $\begin{array}{c}527.75 \\
(274.342)\end{array}$ & $\begin{array}{c}164.67 \\
(416.584)\end{array}$ & $\begin{array}{c}316.16 \\
(124.897)\end{array}$ & $\begin{array}{c}124.07 \\
(30.287)\end{array}$ & $\begin{array}{c}160.09 \\
(236.773)\end{array}$ & $\begin{array}{c}70.06 \\
(277.196)\end{array}$ & $\begin{array}{c}182.65 \\
(94.316)\end{array}$ \\
\hline Age square $* 100$ & $\begin{array}{c}-89.71 \\
(32.818)\end{array}$ & $\begin{array}{c}-425.06 \\
(480.119)\end{array}$ & $\begin{array}{l}-1337.32 \\
(560.714)\end{array}$ & $\begin{array}{c}-420.82 \\
(237.539)\end{array}$ & $\begin{array}{l}-240.09 \\
(45.567)\end{array}$ & $\begin{array}{c}-741.25 \\
(438.906)\end{array}$ & $\begin{array}{c}-88.86 \\
(723.619)\end{array}$ & $\begin{array}{c}-396.71 \\
(163.222)\end{array}$ & $\begin{array}{l}-200.47 \\
(41.188)\end{array}$ & $\begin{array}{c}-150.20 \\
(392.369)\end{array}$ & $\begin{array}{c}50.19 \\
(461.426)\end{array}$ & $\begin{array}{c}-216.54 \\
(137.574)\end{array}$ \\
\hline $\begin{array}{l}\text { Education lower than } 12 \\
\text { years }\end{array}$ & $\begin{array}{l}-1251.00 \\
(74.514)\end{array}$ & $\begin{array}{l}-2561.01 \\
(461.216)\end{array}$ & $\begin{array}{l}-3266.04 \\
(631.815)\end{array}$ & $\begin{array}{l}-2641.22 \\
(467.455)\end{array}$ & $\begin{array}{l}-1692.26 \\
(105.533)\end{array}$ & $\begin{array}{l}-3041.44 \\
(359.793)\end{array}$ & $\begin{array}{l}-3147.08 \\
(360.128)\end{array}$ & $\begin{array}{l}-3140.74 \\
(176.340)\end{array}$ & $\begin{array}{c}-1443.14 \\
(103.449)\end{array}$ & $\begin{array}{l}-2473.80 \\
(260.831)\end{array}$ & $\begin{array}{c}-2060.43 \\
(280.235)\end{array}$ & $\begin{array}{l}-2296.92 \\
(134.369)\end{array}$ \\
\hline Nonwhite & $\begin{array}{c}-5.77 \\
(104.149)\end{array}$ & $\begin{array}{c}44.20 \\
(1249.438)\end{array}$ & $\begin{array}{c}588.53 \\
(1322.456)\end{array}$ & $\begin{array}{c}32.09 \\
(394.323)\end{array}$ & $\begin{array}{c}-446.53 \\
(153.377)\end{array}$ & $\begin{array}{c}-184.08 \\
(1257.249)\end{array}$ & $\begin{array}{c}-393.90 \\
(763.697)\end{array}$ & $\begin{array}{c}-167.77 \\
(254.634)\end{array}$ & $\begin{array}{c}-225.57 \\
(113.837)\end{array}$ & $\begin{array}{c}-377.09 \\
(501.230)\end{array}$ & $\begin{array}{c}641.58 \\
(385.692)\end{array}$ & $\begin{array}{c}50.37 \\
(174.211)\end{array}$ \\
\hline Number of children & $\begin{array}{l}-109.21 \\
(26.180)\end{array}$ & $\begin{array}{c}-596.37 \\
(164.349)\end{array}$ & $\begin{array}{c}-702.10 \\
(287.391)\end{array}$ & $\begin{array}{c}-382.36 \\
(113.981)\end{array}$ & $\begin{array}{c}-60.84 \\
(38.938)\end{array}$ & $\begin{array}{c}-335.75 \\
(169.086)\end{array}$ & $\begin{array}{c}-541.25 \\
(178.658)\end{array}$ & $\begin{array}{l}-291.52 \\
(84.241)\end{array}$ & $\begin{array}{c}4.79 \\
(47.189)\end{array}$ & $\begin{array}{c}-26.40 \\
(148.119)\end{array}$ & $\begin{array}{c}-26.10 \\
(154.791)\end{array}$ & $\begin{array}{l}-31.08 \\
(78.477)\end{array}$ \\
\hline Age of the youngest child & $\begin{array}{c}29.61 \\
(11.133)\end{array}$ & $\begin{array}{c}-59.82 \\
(77.516)\end{array}$ & $\begin{array}{c}-79.60 \\
(134.367)\end{array}$ & $\begin{array}{c}-51.16 \\
(77.098)\end{array}$ & $\begin{array}{c}-16.39 \\
(15.377)\end{array}$ & $\begin{array}{l}-152.59 \\
(74.100)\end{array}$ & $\begin{array}{l}-167.72 \\
(66.105)\end{array}$ & $\begin{array}{c}-85.55 \\
(38.761)\end{array}$ & $\begin{array}{c}-51.22 \\
(14.625)\end{array}$ & $\begin{array}{c}-88.45 \\
(48.909)\end{array}$ & $\begin{array}{l}-128.83 \\
(54.476)\end{array}$ & $\begin{array}{c}-61.53 \\
(26.876)\end{array}$ \\
\hline $\begin{array}{l}\text { On welfare } 7-12 \text { months in } \\
\text { prior } 2 \text { years }\end{array}$ & $\begin{array}{c}-16.95 \\
(83.414)\end{array}$ & $\begin{array}{c}177.76 \\
(618.962)\end{array}$ & $\begin{array}{c}524.50 \\
(734.041)\end{array}$ & $\begin{array}{c}1276.00 \\
(491.417)\end{array}$ & $\begin{array}{c}147.26 \\
(111.680)\end{array}$ & $\begin{array}{c}1025.45 \\
(499.881)\end{array}$ & $\begin{array}{c}1423.47 \\
(502.790)\end{array}$ & $\begin{array}{c}1354.36 \\
(316.008)\end{array}$ & $\begin{array}{c}-302.66 \\
(107.258)\end{array}$ & $\begin{array}{c}-44.44 \\
(381.297)\end{array}$ & $\begin{array}{c}5.64 \\
(410.614)\end{array}$ & $\begin{array}{c}742.09 \\
(216.262)\end{array}$ \\
\hline $\begin{array}{l}\text { On welfare } 13-23 \text { months } \\
\text { in prior } 2 \text { years }\end{array}$ & $\begin{array}{c}52.13 \\
(93.052)\end{array}$ & $\begin{array}{c}-699.61 \\
(618.990)\end{array}$ & $\begin{array}{c}135.34 \\
(702.940)\end{array}$ & $\begin{array}{c}1101.88 \\
(470.010)\end{array}$ & $\begin{array}{c}315.89 \\
(121.850)\end{array}$ & $\begin{array}{c}1105.96 \\
(535.519)\end{array}$ & $\begin{array}{c}1624.07 \\
(463.963)\end{array}$ & $\begin{array}{c}1599.11 \\
(360.411)\end{array}$ & $\begin{array}{c}-324.32 \\
(112.138)\end{array}$ & $\begin{array}{c}19.40 \\
(400.528)\end{array}$ & $\begin{array}{c}248.69 \\
(401.176)\end{array}$ & $\begin{array}{c}759.12 \\
(313.031)\end{array}$ \\
\hline $\begin{array}{l}\text { On welfare } 24 \text { months in } \\
\text { prior } 2 \text { years }\end{array}$ & $\begin{array}{c}9.68 \\
(97.831)\end{array}$ & $\begin{array}{c}-855.38 \\
(668.859)\end{array}$ & $\begin{array}{c}-254.42 \\
(951.925)\end{array}$ & $\begin{array}{c}1036.67 \\
(466.595)\end{array}$ & $\begin{array}{c}780.68 \\
(141.303)\end{array}$ & $\begin{array}{c}790.09 \\
(567.895)\end{array}$ & $\begin{array}{c}2627.30 \\
(571.842)\end{array}$ & $\begin{array}{c}2465.23 \\
(504.518)\end{array}$ & $\begin{array}{c}121.75 \\
(133.374)\end{array}$ & $\begin{array}{c}775.81 \\
(505.713)\end{array}$ & $\begin{array}{c}580.14 \\
(524.849)\end{array}$ & $\begin{array}{c}1979.14 \\
(440.303)\end{array}$ \\
\hline $\begin{array}{l}\text { Percent of previous } 8 \\
\text { quarters working }\end{array}$ & $\begin{array}{c}73.32 \\
(636.677)\end{array}$ & $\begin{array}{c}-771.22 \\
(2759.177)\end{array}$ & $\begin{array}{c}501.90 \\
(3321.710)\end{array}$ & $\begin{array}{c}-3192.52 \\
(6723.817)\end{array}$ & $\begin{array}{c}293.82 \\
(741.512)\end{array}$ & $\begin{array}{c}-993.17 \\
(2100.008)\end{array}$ & $\begin{array}{c}-5932.98 \\
(2663.276)\end{array}$ & $\begin{array}{c}-3800.95 \\
(2182.493)\end{array}$ & $\begin{array}{l}-1606.59 \\
(961.098)\end{array}$ & $\begin{array}{c}-2834.40 \\
(1033.978)\end{array}$ & $\begin{array}{c}-6209.42 \\
(1260.362)\end{array}$ & $\begin{array}{l}-2101.07 \\
(972.659)\end{array}$ \\
\hline $\begin{array}{l}\text { Working all of previous } 8 \\
\text { qtrs }\end{array}$ & $\begin{array}{c}-771.41 \\
(327.354)\end{array}$ & $\begin{array}{l}-1158.80 \\
(1262.815)\end{array}$ & $\begin{array}{c}-965.26 \\
(1168.373)\end{array}$ & $\begin{array}{c}-990.64 \\
(785.605)\end{array}$ & $\begin{array}{c}-999.13 \\
(318.431)\end{array}$ & $\begin{array}{c}74.34 \\
(806.162)\end{array}$ & $\begin{array}{c}-322.37 \\
(529.493)\end{array}$ & $\begin{array}{c}-167.71 \\
(300.308)\end{array}$ & $\begin{array}{c}-876.56 \\
(336.829)\end{array}$ & $\begin{array}{c}494.40 \\
(566.991)\end{array}$ & $\begin{array}{c}938.41 \\
(497.355)\end{array}$ & $\begin{array}{c}368.39 \\
(286.310)\end{array}$ \\
\hline $\begin{array}{l}\text { No work in any of } \\
\text { previous } 8 \text { quarters }\end{array}$ & $\begin{array}{c}46.13 \\
(168.562)\end{array}$ & $\begin{array}{c}39.94 \\
(1383.282)\end{array}$ & $\begin{array}{c}-508.08 \\
(2072.273)\end{array}$ & $\begin{array}{c}1177.09 \\
(5180.344)\end{array}$ & $\begin{array}{c}611.86 \\
(199.399)\end{array}$ & $\begin{array}{c}963.72 \\
(1666.427)\end{array}$ & $\begin{array}{c}2482.48 \\
(1327.115)\end{array}$ & $\begin{array}{c}459.23 \\
(2472.677)\end{array}$ & $\begin{array}{c}810.32 \\
(271.798)\end{array}$ & $\begin{array}{c}1418.63 \\
(733.668)\end{array}$ & $\begin{array}{c}-268.20 \\
(1042.223)\end{array}$ & $\begin{array}{c}-296.54 \\
(899.754)\end{array}$ \\
\hline $\begin{array}{l}\text { Total annual earnings in } \\
\text { the prior year } * 1000\end{array}$ & $\begin{array}{c}85.41 \\
(71.061)\end{array}$ & $\begin{array}{c}733.48 \\
(153.370)\end{array}$ & $\begin{array}{c}816.01 \\
(200.580)\end{array}$ & $\begin{array}{c}552.57 \\
(660.379)\end{array}$ & $\begin{array}{c}126.90 \\
(69.465)\end{array}$ & $\begin{array}{c}808.14 \\
(132.578)\end{array}$ & $\begin{array}{c}815.54 \\
(72.762)\end{array}$ & $\begin{array}{c}868.60 \\
(351.773)\end{array}$ & $\begin{array}{c}130.30 \\
(93.114)\end{array}$ & $\begin{array}{c}688.33 \\
(67.336)\end{array}$ & $\begin{array}{c}706.30 \\
(65.753)\end{array}$ & $\begin{array}{c}856.32 \\
(139.955)\end{array}$ \\
\hline $\begin{array}{l}\text { Total annual earnings two } \\
\text { years prior * } 1000\end{array}$ & $\begin{array}{c}242.91 \\
(43.555)\end{array}$ & $\begin{array}{c}362.31 \\
(156.069)\end{array}$ & $\begin{array}{c}274.88 \\
(143.340)\end{array}$ & $\begin{array}{c}468.41 \\
(387.404)\end{array}$ & $\begin{array}{c}319.15 \\
(50.088)\end{array}$ & $\begin{array}{c}369.36 \\
(138.304)\end{array}$ & $\begin{array}{l}560.27 \\
(81.496)\end{array}$ & $\begin{array}{c}466.36 \\
(125.004)\end{array}$ & $\begin{array}{c}382.38 \\
(66.542)\end{array}$ & $\begin{array}{c}423.79 \\
(113.803)\end{array}$ & $\begin{array}{c}430.40 \\
(78.796)\end{array}$ & $\begin{array}{c}366.02 \\
(94.156)\end{array}$ \\
\hline St. Louis central & $\begin{array}{c}-110.79 \\
(107.441)\end{array}$ & $\begin{array}{c}-439.92 \\
(2060.587)\end{array}$ & $\begin{array}{c}3411.00 \\
(1939.221)\end{array}$ & $\begin{array}{c}2067.41 \\
(589.519)\end{array}$ & $\begin{array}{c}165.03 \\
(152.694)\end{array}$ & $\begin{array}{c}2879.81 \\
(1237.665)\end{array}$ & $\begin{array}{c}2663.45 \\
(837.417)\end{array}$ & $\begin{array}{c}2541.99 \\
(270.331)\end{array}$ & n.a. & n.a. & n.a. & n.a. \\
\hline Kansas City central & $\begin{array}{c}176.33 \\
(130.483)\end{array}$ & $\begin{array}{c}313.64 \\
(2088.122)\end{array}$ & $\begin{array}{c}3922.93 \\
(2335.676)\end{array}$ & $\begin{array}{c}1928.21 \\
(296.192)\end{array}$ & $\begin{array}{c}560.94 \\
(194.842)\end{array}$ & $\begin{array}{c}2689.35 \\
(1472.653)\end{array}$ & $\begin{array}{c}2130.40 \\
(1094.930)\end{array}$ & $\begin{array}{c}2767.79 \\
(402.672)\end{array}$ & n.a. & n.a. & n.a. & n.a. \\
\hline Charlotte central & n.a. & n.a. & n.a. & n.a. & n.a. & n.a. & n.a. & n.a. & $\begin{array}{c}336.47 \\
(167.184)\end{array}$ & $\begin{array}{c}1656.20 \\
(477.361)\end{array}$ & $\begin{array}{c}1210.55 \\
(549.650)\end{array}$ & $\begin{array}{c}1186.90 \\
(247.769)\end{array}$ \\
\hline Suburban metro & $\begin{array}{l}467.3197 \\
(151.077)\end{array}$ & $\begin{array}{c}-58.57 \\
(2156.926)\end{array}$ & $\begin{array}{c}2327.39 \\
(2323.367)\end{array}$ & $\begin{array}{c}1263.28 \\
(542.850)\end{array}$ & $\begin{array}{c}807.3162 \\
(217.453)\end{array}$ & $\begin{array}{c}1385.62 \\
(1343.566)\end{array}$ & $\begin{array}{c}761.79 \\
(1020.780)\end{array}$ & $\begin{array}{c}1904.44 \\
(391.484)\end{array}$ & $\begin{array}{c}451.59 \\
(264.680)\end{array}$ & $\begin{array}{c}1321.65 \\
(624.037)\end{array}$ & $\begin{array}{c}424.03 \\
(831.756)\end{array}$ & $\begin{array}{c}1007.78 \\
(364.096)\end{array}$ \\
\hline Small metro & $\begin{array}{c}175.33 \\
(130.354)\end{array}$ & $\begin{array}{c}-845.39 \\
(1525.989)\end{array}$ & $\begin{array}{c}2423.20 \\
(1943.385)\end{array}$ & $\begin{array}{c}494.97 \\
(233.173)\end{array}$ & $\begin{array}{c}272.08 \\
(175.411)\end{array}$ & $\begin{array}{c}-377.10 \\
(1023.937)\end{array}$ & $\begin{array}{c}-1036.79 \\
(1047.379)\end{array}$ & $\begin{array}{c}529.35 \\
(233.254)\end{array}$ & $\begin{array}{c}136.73 \\
(106.359)\end{array}$ & $\begin{array}{c}417.47 \\
(291.938)\end{array}$ & $\begin{array}{c}104.79 \\
(314.099)\end{array}$ & $\begin{array}{c}436.59 \\
(139.192)\end{array}$ \\
\hline Quarter 2 & $\begin{array}{l}-40.80 \\
(39.340)\end{array}$ & $\begin{array}{c}-313.26 \\
(311.624)\end{array}$ & $\begin{array}{l}-421.06 \\
(661.797)\end{array}$ & $\begin{array}{c}-277.15 \\
(827.097)\end{array}$ & $\begin{array}{l}-234.66 \\
(58.977)\end{array}$ & $\begin{array}{c}190.82 \\
(396.595)\end{array}$ & $\begin{array}{l}-1186.69 \\
(628.312)\end{array}$ & $\begin{array}{c}-336.02 \\
(213.165)\end{array}$ & $\begin{array}{l}-326.82 \\
(77.562)\end{array}$ & $\begin{array}{c}-57.65 \\
(211.173)\end{array}$ & $\begin{array}{l}-1217.33 \\
(302.078)\end{array}$ & $\begin{array}{c}-99.66 \\
(102.644)\end{array}$ \\
\hline Quarter 3 & $\begin{array}{l}-192.26 \\
(65.804)\end{array}$ & $\begin{array}{c}-78.75 \\
(542.144)\end{array}$ & $\begin{array}{c}8.81 \\
(1058.268)\end{array}$ & $\begin{array}{c}-260.65 \\
(1250.939)\end{array}$ & $\begin{array}{l}-646.91 \\
(88.155)\end{array}$ & $\begin{array}{c}-342.16 \\
(525.959)\end{array}$ & $\begin{array}{c}-977.91 \\
(753.248)\end{array}$ & $\begin{array}{c}-379.42 \\
(384.941)\end{array}$ & $\begin{array}{c}-774.23 \\
(110.133)\end{array}$ & $\begin{array}{c}-250.44 \\
(258.136)\end{array}$ & $\begin{array}{c}-1216.56 \\
(352.630)\end{array}$ & $\begin{array}{c}-155.34 \\
(123.589)\end{array}$ \\
\hline Quarter 4 & $\begin{array}{c}11.92 \\
(67.160)\end{array}$ & $\begin{array}{c}131.41 \\
(613.969)\end{array}$ & $\begin{array}{c}-210.81 \\
(1038.988)\end{array}$ & $\begin{array}{c}-260.98 \\
(1240.508)\end{array}$ & $\begin{array}{l}-434.51 \\
(78.911)\end{array}$ & $\begin{array}{c}-411.91 \\
(395.105)\end{array}$ & $\begin{array}{l}-1385.91 \\
(746.372)\end{array}$ & $\begin{array}{c}-622.96 \\
(336.953)\end{array}$ & $\begin{array}{c}-617.95 \\
(66.574)\end{array}$ & $\begin{array}{c}-684.45 \\
(259.929)\end{array}$ & $\begin{array}{c}-1809.33 \\
(355.230)\end{array}$ & $\begin{array}{l}-677.28 \\
(81.875)\end{array}$ \\
\hline Lambda & $\begin{array}{c}3272.27 \\
(797.709)\end{array}$ & $\begin{array}{c}309.66 \\
(3937.927)\end{array}$ & $\begin{array}{c}4293.85 \\
(4346.960)\end{array}$ & $\begin{array}{c}-1980.73 \\
(10232.980)\end{array}$ & $\begin{array}{c}3283.79 \\
(916.216)\end{array}$ & $\begin{array}{c}3039.09 \\
(4765.997)\end{array}$ & $\begin{array}{c}-1792.84 \\
(2742.797)\end{array}$ & $\begin{array}{c}304.30 \\
(5472.752)\end{array}$ & $\begin{array}{c}4126.49 \\
(1183.317)\end{array}$ & $\begin{array}{c}-416.60 \\
(1485.739)\end{array}$ & $\begin{array}{c}-1303.06 \\
(1162.456)\end{array}$ & $\begin{array}{c}2032.95 \\
(1616.570)\end{array}$ \\
\hline $\mathrm{N}$ & 209,325 & 6,230 & 3,744 & 69,861 & 129,440 & 9,921 & 7,485 & 72,596 & 130,894 & 12,148 & 10,073 & 95,254 \\
\hline
\end{tabular}

Note: Standard errors are reported in parentheses. All standrard errors have been adjusted for the estimation error in the inverse Mill's ratio. Estimation takes account of the correlation of errors for recipients who appear in the data multiple times. 
Appendix Table A-3: Estimates for Regression Equations Predicting Earnings in the Eighth Quarter after Reference Quarter, Controlling for SelfSelection into Job Category

\begin{tabular}{|c|c|c|c|c|c|c|c|c|c|c|c|c|}
\hline & \multicolumn{8}{|c|}{ Missouri } & \multirow{2}{*}{\multicolumn{4}{|c|}{$\begin{array}{c}\text { North Carolina } \\
1997 \\
\end{array}$}} \\
\hline & \multicolumn{4}{|c|}{1993} & \multicolumn{4}{|c|}{1997} & & & & \\
\hline & & & Job in & & & & Job in & & \multicolumn{4}{|c|}{ Job in $\mathrm{Te}$} \\
\hline & No Job & $\begin{array}{l}\text { Job in } \\
\text { Temp } \\
\text { Help }\end{array}$ & $\begin{array}{c}\text { Temp Help } \\
\text { and Other } \\
\text { Industry }\end{array}$ & $\begin{array}{c}\text { Job, but } \\
\text { none in } \\
\text { Temp Help }\end{array}$ & No Job & $\begin{array}{l}\text { Job in } \\
\text { Temp } \\
\text { Help }\end{array}$ & $\begin{array}{c}\text { Temp Help } \\
\text { and Other } \\
\text { Industry }\end{array}$ & $\begin{array}{c}\text { Job, but } \\
\text { none in } \\
\text { Temp Help }\end{array}$ & No Job & $\begin{array}{l}\text { Job in Temp } \\
\text { Help }\end{array}$ & $\begin{array}{l}\text { Help and } \\
\text { Other } \\
\text { Industry }\end{array}$ & $\begin{array}{c}\text { Job, but } \\
\text { none in } \\
\text { Temp Help }\end{array}$ \\
\hline Constant & $\begin{array}{c}537.57 \\
(101.357)\end{array}$ & $\begin{array}{c}1846.11 \\
(2834.228)\end{array}$ & $\begin{array}{c}-3528.67 \\
(2728.077)\end{array}$ & $\begin{array}{c}759.52 \\
(1046.970)\end{array}$ & $\begin{array}{c}206.01 \\
(122.023)\end{array}$ & $\begin{array}{c}-279.27 \\
(1591.796)\end{array}$ & $\begin{array}{c}1787.27 \\
(1509.506)\end{array}$ & $\begin{array}{c}675.87 \\
(645.646)\end{array}$ & $\begin{array}{c}334.54 \\
(127.077)\end{array}$ & $\begin{array}{l}1234.53 \\
(731.193)\end{array}$ & $\begin{array}{c}1749.37 \\
(758.787)\end{array}$ & $\begin{array}{c}501.60 \\
(232.437)\end{array}$ \\
\hline Age & $\begin{array}{c}5.31 \\
(5.123)\end{array}$ & $\begin{array}{c}-15.10 \\
(56.194)\end{array}$ & $\begin{array}{c}124.07 \\
(61.132)\end{array}$ & $\begin{array}{c}32.16 \\
(26.076)\end{array}$ & $\begin{array}{l}26.21 \\
(6.470)\end{array}$ & $\begin{array}{c}56.56 \\
(38.906)\end{array}$ & $\begin{array}{c}-17.67 \\
(48.425)\end{array}$ & $\begin{array}{c}29.48 \\
(15.808)\end{array}$ & $\begin{array}{c}24.00 \\
(5.494)\end{array}$ & $\begin{array}{c}11.30 \\
(29.719)\end{array}$ & $\begin{array}{c}-2.54 \\
(35.701)\end{array}$ & $\begin{array}{c}16.70 \\
(11.390)\end{array}$ \\
\hline Age square *100 & $\begin{array}{l}-21.61 \\
(6.481)\end{array}$ & $\begin{array}{c}20.71 \\
(90.930)\end{array}$ & $\begin{array}{l}-178.72 \\
(98.284)\end{array}$ & $\begin{array}{c}-35.08 \\
(29.157)\end{array}$ & $\begin{array}{l}-51.42 \\
(8.688)\end{array}$ & $\begin{array}{c}-79.18 \\
(62.017)\end{array}$ & $\begin{array}{c}38.81 \\
(80.907)\end{array}$ & $\begin{array}{c}-46.35 \\
(21.788)\end{array}$ & $\begin{array}{l}-46.99 \\
(7.346)\end{array}$ & $\begin{array}{c}-11.56 \\
(48.522)\end{array}$ & $\begin{array}{c}13.72 \\
(58.828)\end{array}$ & $\begin{array}{c}-24.80 \\
(17.333)\end{array}$ \\
\hline $\begin{array}{l}\text { Education lower than } 12 \\
\text { years }\end{array}$ & $\begin{array}{l}-273.14 \\
(15.956)\end{array}$ & $\begin{array}{l}-437.54 \\
(84.955)\end{array}$ & $\begin{array}{l}-444.80 \\
(112.515)\end{array}$ & $\begin{array}{l}-411.88 \\
(49.723)\end{array}$ & $\begin{array}{l}-311.06 \\
(20.748)\end{array}$ & $\begin{array}{l}-418.93 \\
(55.776)\end{array}$ & $\begin{array}{l}-365.83 \\
(61.579)\end{array}$ & $\begin{array}{l}-453.03 \\
(26.939)\end{array}$ & $\begin{array}{l}-279.27 \\
(19.794)\end{array}$ & $\begin{array}{l}-338.10 \\
(45.196)\end{array}$ & $\begin{array}{l}-298.47 \\
(47.843)\end{array}$ & $\begin{array}{l}-350.04 \\
(23.660)\end{array}$ \\
\hline Nonwhite & $\begin{array}{c}-5.02 \\
(20.850)\end{array}$ & $\begin{array}{c}88.81 \\
(246.396)\end{array}$ & $\begin{array}{c}152.30 \\
(241.645)\end{array}$ & $\begin{array}{c}70.08 \\
(47.090)\end{array}$ & $\begin{array}{l}-128.61 \\
(31.225)\end{array}$ & $\begin{array}{c}-15.84 \\
(142.587)\end{array}$ & $\begin{array}{c}-37.90 \\
(112.452)\end{array}$ & $\begin{array}{c}-17.14 \\
(38.834)\end{array}$ & $\begin{array}{c}-27.67 \\
(22.486)\end{array}$ & $\begin{array}{c}-8.93 \\
(80.083)\end{array}$ & $\begin{array}{c}137.15 \\
(65.133)\end{array}$ & $\begin{array}{c}60.22 \\
(27.333)\end{array}$ \\
\hline Number of children & $\begin{array}{l}-18.40 \\
(5.429)\end{array}$ & $\begin{array}{c}-81.60 \\
(33.647)\end{array}$ & $\begin{array}{c}-98.79 \\
(57.012)\end{array}$ & $\begin{array}{c}-54.34 \\
(15.281)\end{array}$ & $\begin{array}{l}-12.52 \\
(7.705)\end{array}$ & $\begin{array}{c}-36.53 \\
(25.078)\end{array}$ & $\begin{array}{c}-44.87 \\
(28.289)\end{array}$ & $\begin{array}{c}-30.88 \\
(12.902)\end{array}$ & $\begin{array}{c}-5.55 \\
(9.346)\end{array}$ & $\begin{array}{c}24.83 \\
(27.029)\end{array}$ & $\begin{array}{c}19.39 \\
(24.980)\end{array}$ & $\begin{array}{c}-15.37 \\
(11.716)\end{array}$ \\
\hline Age of the youngest child & $\begin{array}{c}6.34 \\
(2.351)\end{array}$ & $\begin{array}{c}-9.02 \\
(14.297)\end{array}$ & $\begin{array}{c}-2.03 \\
(27.292)\end{array}$ & $\begin{array}{c}-4.44 \\
(8.567)\end{array}$ & $\begin{array}{c}-4.59 \\
(2.980)\end{array}$ & $\begin{array}{l}-28.67 \\
(9.995)\end{array}$ & $\begin{array}{c}-21.15 \\
(10.920)\end{array}$ & $\begin{array}{c}-8.61 \\
(5.238)\end{array}$ & $\begin{array}{l}-11.16 \\
(2.749)\end{array}$ & $\begin{array}{c}-9.77 \\
(8.160)\end{array}$ & $\begin{array}{l}-12.81 \\
(8.911)\end{array}$ & $\begin{array}{c}-5.88 \\
(3.185)\end{array}$ \\
\hline $\begin{array}{l}\text { On welfare } 7-12 \text { months } \\
\text { in prior } 2 \text { years }\end{array}$ & $\begin{array}{c}9.59 \\
(16.248)\end{array}$ & $\begin{array}{c}101.30 \\
(109.528)\end{array}$ & $\begin{array}{c}117.91 \\
(134.608)\end{array}$ & $\begin{array}{c}118.25 \\
(52.266)\end{array}$ & $\begin{array}{c}50.08 \\
(21.937)\end{array}$ & $\begin{array}{c}211.09 \\
(79.748)\end{array}$ & $\begin{array}{c}247.32 \\
(91.996)\end{array}$ & $\begin{array}{c}159.18 \\
(41.011)\end{array}$ & $\begin{array}{c}-66.99 \\
(20.207)\end{array}$ & $\begin{array}{c}-79.30 \\
(70.369)\end{array}$ & $\begin{array}{c}-93.16 \\
(72.779)\end{array}$ & $\begin{array}{c}45.54 \\
(23.472)\end{array}$ \\
\hline $\begin{array}{l}\text { On welfare } 13-23 \text { months } \\
\text { in prior } 2 \text { years }\end{array}$ & $\begin{array}{c}24.88 \\
(18.137)\end{array}$ & $\begin{array}{c}-37.09 \\
(103.587)\end{array}$ & $\begin{array}{c}82.87 \\
(141.725)\end{array}$ & $\begin{array}{c}111.04 \\
(52.772)\end{array}$ & $\begin{array}{c}73.11 \\
(23.560)\end{array}$ & $\begin{array}{c}205.79 \\
(77.375)\end{array}$ & $\begin{array}{c}220.39 \\
(77.346)\end{array}$ & $\begin{array}{c}206.83 \\
(44.891)\end{array}$ & $\begin{array}{c}-59.69 \\
(21.120)\end{array}$ & $\begin{array}{c}-67.04 \\
(68.360)\end{array}$ & $\begin{array}{c}-50.86 \\
69.88472 .\end{array}$ & $\begin{array}{c}51.44 \\
(29.920)\end{array}$ \\
\hline $\begin{array}{l}\text { On welfare } 24 \text { months in } \\
\text { prior } 2 \text { years }\end{array}$ & $\begin{array}{c}41.02 \\
(19.235)\end{array}$ & $\begin{array}{c}9.13 \\
(112.474)\end{array}$ & $\begin{array}{c}12.34 \\
(154.435)\end{array}$ & $\begin{array}{c}106.65 \\
(55.928)\end{array}$ & $\begin{array}{c}181.17 \\
(27.671)\end{array}$ & $\begin{array}{c}144.30 \\
(84.028)\end{array}$ & $\begin{array}{c}271.05 \\
(92.571)\end{array}$ & $\begin{array}{c}296.80 \\
(59.624)\end{array}$ & $\begin{array}{c}48.65 \\
(25.017)\end{array}$ & $\begin{array}{c}42.23 \\
(79.814)\end{array}$ & $\begin{array}{c}-17.76 \\
(86.371)\end{array}$ & $\begin{array}{c}262.32 \\
(63.114)\end{array}$ \\
\hline $\begin{array}{l}\text { Percent of previous } 8 \\
\text { quarters working }\end{array}$ & $\begin{array}{c}-70.81 \\
(118.560)\end{array}$ & $\begin{array}{c}-159.42 \\
(442.962)\end{array}$ & $\begin{array}{c}478.57 \\
(522.778)\end{array}$ & $\begin{array}{c}-209.53 \\
(633.517)\end{array}$ & $\begin{array}{c}-144.28 \\
(135.086)\end{array}$ & $\begin{array}{c}-328.51 \\
(256.208)\end{array}$ & $\begin{array}{c}-766.54 \\
(373.951)\end{array}$ & $\begin{array}{c}-438.24 \\
(243.982)\end{array}$ & $\begin{array}{c}-312.50 \\
(170.664)\end{array}$ & $\begin{array}{c}-257.77 \\
(142.928)\end{array}$ & $\begin{array}{c}-639.11 \\
(202.207)\end{array}$ & $\begin{array}{c}-152.56 \\
(167.912)\end{array}$ \\
\hline $\begin{array}{l}\text { Working all of previous } 8 \\
\text { qtrs }\end{array}$ & $\begin{array}{l}-108.66 \\
(61.240)\end{array}$ & $\begin{array}{c}-143.97 \\
(236.195)\end{array}$ & $\begin{array}{c}-206.41 \\
(200.410)\end{array}$ & $\begin{array}{c}-92.85 \\
(86.499)\end{array}$ & $\begin{array}{l}-204.70 \\
(59.219)\end{array}$ & $\begin{array}{c}13.36 \\
(117.004)\end{array}$ & $\begin{array}{c}65.49 \\
(92.939)\end{array}$ & $\begin{array}{c}31.89 \\
(48.719)\end{array}$ & $\begin{array}{l}-165.62 \\
(62.741)\end{array}$ & $\begin{array}{c}32.06 \\
(91.765)\end{array}$ & $\begin{array}{c}132.30 \\
(77.410)\end{array}$ & $\begin{array}{c}36.22 \\
(32.439)\end{array}$ \\
\hline $\begin{array}{l}\text { No work in any of } \\
\text { previous } 8 \text { quarters }\end{array}$ & $\begin{array}{c}8.69 \\
(32.079)\end{array}$ & $\begin{array}{c}16.82 \\
(284.191)\end{array}$ & $\begin{array}{l}-187.88 \\
(370.432)\end{array}$ & $\begin{array}{c}79.85 \\
(486.437)\end{array}$ & $\begin{array}{c}154.95 \\
(38.188)\end{array}$ & $\begin{array}{c}82.89 \\
(173.754)\end{array}$ & $\begin{array}{c}144.52 \\
(204.177)\end{array}$ & $\begin{array}{c}36.47 \\
(257.060)\end{array}$ & $\begin{array}{c}152.83 \\
(51.017)\end{array}$ & $\begin{array}{c}176.85 \\
(112.665)\end{array}$ & $\begin{array}{c}-61.85 \\
(166.069)\end{array}$ & $\begin{array}{c}-76.81 \\
(90.097)\end{array}$ \\
\hline $\begin{array}{l}\text { Total annual earnings in } \\
\text { the prior year } * 1000\end{array}$ & $\begin{array}{c}3.81 \\
(11.938)\end{array}$ & $\begin{array}{c}93.82 \\
(25.255)\end{array}$ & $\begin{array}{c}112.99 \\
(43.257)\end{array}$ & $\begin{array}{c}69.10 \\
(62.643)\end{array}$ & $\begin{array}{c}2.66 \\
(12.851)\end{array}$ & $\begin{array}{c}110.55 \\
(16.100)\end{array}$ & $\begin{array}{c}115.62 \\
(12.912)\end{array}$ & $\begin{array}{c}101.92 \\
(36.233)\end{array}$ & $\begin{array}{c}11.99 \\
(16.523)\end{array}$ & $\begin{array}{c}93.62 \\
(10.808)\end{array}$ & $\begin{array}{c}97.46 \\
(10.737)\end{array}$ & $\begin{array}{c}109.37 \\
(138.592)\end{array}$ \\
\hline $\begin{array}{l}\text { Total annual earnings two } \\
\text { years prior } * 1000\end{array}$ & $\begin{array}{c}48.53 \\
(8.009)\end{array}$ & $\begin{array}{c}70.87 \\
(27.060)\end{array}$ & $\begin{array}{c}28.94 \\
(23.446)\end{array}$ & $\begin{array}{c}56.85 \\
(36.500)\end{array}$ & $\begin{array}{c}60.69 \\
(8.482)\end{array}$ & $\begin{array}{c}56.84 \\
(16.763)\end{array}$ & $\begin{array}{c}72.27 \\
(14.180)\end{array}$ & $\begin{array}{c}62.88 \\
(14.087)\end{array}$ & $\begin{array}{c}69.29 \\
(11.535)\end{array}$ & $\begin{array}{c}51.56 \\
(11.539)\end{array}$ & $\begin{array}{c}50.01 \\
(11.422)\end{array}$ & $\begin{array}{c}46.58 \\
(9.624)\end{array}$ \\
\hline St. Louis central & $\begin{array}{c}-15.23 \\
(21.558)\end{array}$ & $\begin{array}{c}-146.63 \\
(364.999)\end{array}$ & $\begin{array}{c}797.65 \\
(317.141)\end{array}$ & $\begin{array}{c}240.15 \\
(62.443)\end{array}$ & $\begin{array}{c}62.99 \\
(31.092)\end{array}$ & $\begin{array}{c}407.85 \\
(156.789)\end{array}$ & $\begin{array}{c}469.50 \\
(110.813)\end{array}$ & $\begin{array}{c}342.82 \\
(41.590)\end{array}$ & n.a. & n.a. & n.a. & n.a. \\
\hline Kansas City central & $\begin{array}{c}21.24 \\
(25.668)\end{array}$ & $\begin{array}{c}-35.47 \\
(369.514)\end{array}$ & $\begin{array}{c}804.85 \\
(392.301)\end{array}$ & $\begin{array}{c}216.64 \\
(44.484)\end{array}$ & $\begin{array}{c}106.16 \\
(38.868)\end{array}$ & $\begin{array}{c}285.84 \\
(181.987)\end{array}$ & $\begin{array}{c}411.96 \\
(137.642)\end{array}$ & $\begin{array}{c}360.64 \\
(52.311)\end{array}$ & n.a. & n.a. & n.a. & n.a. \\
\hline Charlotte central & n.a. & n.a. & n.a. & n.a. & n.a. & n.a. & n.a. & n.a. & $\begin{array}{c}94.08 \\
(33.039)\end{array}$ & $\begin{array}{c}270.82 \\
(81.557)\end{array}$ & $\begin{array}{c}305.83 \\
(94.155)\end{array}$ & $\begin{array}{c}215.95 \\
(30.367)\end{array}$ \\
\hline Suburban metro & $\begin{array}{c}98.21804 \\
32.1256\end{array}$ & $\begin{array}{c}-23.79 \\
(380.044)\end{array}$ & $\begin{array}{c}586.94 \\
(377.470)\end{array}$ & $\begin{array}{c}178.93 \\
(62.437)\end{array}$ & $\begin{array}{l}142.2807 \\
(41.684)\end{array}$ & $\begin{array}{c}61.59 \\
(168.273)\end{array}$ & $\begin{array}{c}183.02 \\
(142.932)\end{array}$ & $\begin{array}{c}283.35 \\
(55.172)\end{array}$ & $\begin{array}{c}76.88 \\
(48.130)\end{array}$ & $\begin{array}{c}145.48 \\
(121.210)\end{array}$ & $\begin{array}{c}168.75 \\
(154.719)\end{array}$ & $\begin{array}{c}169.98 \\
(42.558)\end{array}$ \\
\hline Small metro & $\begin{array}{l}35.18802 \\
(26.587)\end{array}$ & $\begin{array}{c}-257.67 \\
(269.070)\end{array}$ & $\begin{array}{c}527.24 \\
(316.161)\end{array}$ & $\begin{array}{c}61.83 \\
(36.360)\end{array}$ & $\begin{array}{c}47.79 \\
(35.600)\end{array}$ & $\begin{array}{c}-88.92 \\
(144.769)\end{array}$ & $\begin{array}{c}-45.88 \\
(133.343)\end{array}$ & $\begin{array}{c}97.91 \\
(38.931)\end{array}$ & $\begin{array}{c}32.35 \\
(20.331)\end{array}$ & $\begin{array}{c}38.04 \\
(47.752)\end{array}$ & $\begin{array}{c}-16.10 \\
(52.400)\end{array}$ & $\begin{array}{c}82.15 \\
(28.695)\end{array}$ \\
\hline Quarter 2 & $\begin{array}{c}25.65 \\
(7.466)\end{array}$ & $\begin{array}{c}6.11 \\
(61.241)\end{array}$ & $\begin{array}{c}69.89 \\
(120.604)\end{array}$ & $\begin{array}{c}50.72 \\
(78.664)\end{array}$ & $\begin{array}{c}40.77 \\
(11.292)\end{array}$ & $\begin{array}{c}155.51 \\
(51.393)\end{array}$ & $\begin{array}{c}83.34 \\
(83.213)\end{array}$ & $\begin{array}{c}138.58 \\
(24.953)\end{array}$ & $\begin{array}{c}12.77 \\
(14.588)\end{array}$ & $\begin{array}{c}175.03 \\
(36.167)\end{array}$ & $\begin{array}{c}1.95 \\
(55.100)\end{array}$ & $\begin{array}{c}110.26 \\
(11.540)\end{array}$ \\
\hline Quarter 3 & $\begin{array}{c}-14.30 \\
(12.505)\end{array}$ & $\begin{array}{c}46.90 \\
(104.255)\end{array}$ & $\begin{array}{c}114.24 \\
(200.090)\end{array}$ & $\begin{array}{c}-8.88 \\
(118.384)\end{array}$ & $\begin{array}{c}13.15 \\
(17.001)\end{array}$ & $\begin{array}{c}167.77 \\
(64.775)\end{array}$ & $\begin{array}{c}202.56 \\
(100.126)\end{array}$ & $\begin{array}{c}166.59 \\
(42.577)\end{array}$ & $\begin{array}{c}-43.89 \\
(20.399)\end{array}$ & $\begin{array}{c}141.68 \\
(44.805)\end{array}$ & $\begin{array}{c}11.08 \\
(61.800)\end{array}$ & $\begin{array}{c}80.72 \\
(13.838)\end{array}$ \\
\hline Quarter 4 & $\begin{array}{c}76.90 \\
(12.872)\end{array}$ & $\begin{array}{c}181.26 \\
(125.287)\end{array}$ & $\begin{array}{c}267.67 \\
(179.692)\end{array}$ & $\begin{array}{c}137.94 \\
(117.792)\end{array}$ & $\begin{array}{c}129.33 \\
(16.060)\end{array}$ & $\begin{array}{c}288.69 \\
(59.242)\end{array}$ & $\begin{array}{c}397.46 \\
(101.986)\end{array}$ & $\begin{array}{c}304.58 \\
(39.363)\end{array}$ & $\begin{array}{c}35.05 \\
(12.823)\end{array}$ & $\begin{array}{c}120.52 \\
(46.462)\end{array}$ & $\begin{array}{c}91.89 \\
(62.679)\end{array}$ & $\begin{array}{c}149.50 \\
(53.427)\end{array}$ \\
\hline Lambda & $\begin{array}{c}584.08 \\
(148.281)\end{array}$ & $\begin{array}{c}-53.39 \\
(763.43)\end{array}$ & $\begin{array}{c}865.38 \\
(747.43)\end{array}$ & $\begin{array}{l}-152.86 \\
(960.41)\end{array}$ & $\begin{array}{c}719.27 \\
(175.573)\end{array}$ & $\begin{array}{c}255.08 \\
(481.714)\end{array}$ & $\begin{array}{c}-136.57 \\
(411.040)\end{array}$ & $\begin{array}{c}55.63 \\
(570.409)\end{array}$ & $\begin{array}{c}656.42 \\
(216.980)\end{array}$ & $\begin{array}{c}-97.65 \\
(239.147)\end{array}$ & $\begin{array}{c}-90.47 \\
(184.193)\end{array}$ & $\begin{array}{c}325.83 \\
(185.669)\end{array}$ \\
\hline $\mathrm{N}$ & 209,325 & 6,230 & 3,744 & 69,861 & 129,440 & 9,921 & 7,485 & 72,596 & 130,894 & 12,148 & 10,073 & 95,254 \\
\hline
\end{tabular}


Appendix Table A-4: Regression Predicting Probability of Leaving Welfare Eight Quarters Later, Controlling for Self-Selection into Job Category

\begin{tabular}{|c|c|c|c|c|c|c|c|c|c|c|c|c|}
\hline & \multicolumn{8}{|c|}{ Missouri } & \multirow{2}{*}{\multicolumn{4}{|c|}{$\begin{array}{c}\text { North Carolina } \\
1997 \\
\end{array}$}} \\
\hline & \multicolumn{4}{|c|}{1993} & \multicolumn{4}{|c|}{1997} & & & & \\
\hline & & & ob in Temp & & & & Job in Tem & & \multicolumn{4}{|c|}{ Job in Temp } \\
\hline & No Job & $\begin{array}{c}\text { Job in Temp } \\
\text { Help }\end{array}$ & $\begin{array}{l}\text { Help and } \\
\text { Other } \\
\text { Industry }\end{array}$ & $\begin{array}{c}\text { Job, but } \\
\text { none in } \\
\text { Temp Help }\end{array}$ & No Job & $\begin{array}{c}\text { Job in Temp } \\
\text { Help }\end{array}$ & $\begin{array}{l}\text { Help and } \\
\text { Other } \\
\text { Industry }\end{array}$ & $\begin{array}{c}\text { Job, but } \\
\text { none in } \\
\text { Temp Help }\end{array}$ & No Job & $\begin{array}{c}\text { Job in Temp } \\
\text { Help }\end{array}$ & $\begin{array}{l}\text { Help and } \\
\text { Other } \\
\text { Industry }\end{array}$ & $\begin{array}{c}\text { Job, but none } \\
\text { in Temp } \\
\text { Help }\end{array}$ \\
\hline Constant & $\begin{array}{c}0.518 \\
(0.041)\end{array}$ & $\begin{array}{l}1.226 \\
(0.524)\end{array}$ & $\begin{array}{c}0.794 \\
(0.478)\end{array}$ & $\begin{array}{c}0.623 \\
(0.099)\end{array}$ & $\begin{array}{c}0.472 \\
(0.050)\end{array}$ & $\begin{array}{c}0.312 \\
(0.252)\end{array}$ & $\begin{array}{c}0.634 \\
(0.301)\end{array}$ & $\begin{array}{c}0.453 \\
(0.070)\end{array}$ & $\begin{array}{c}0.444 \\
(0.049)\end{array}$ & $\begin{array}{c}0.886 \\
(0.163)\end{array}$ & $\begin{array}{l}1.1526 \\
(0.158)\end{array}$ & $\begin{array}{c}0.845 \\
(0.053)\end{array}$ \\
\hline Age & $\begin{array}{l}0.001 \\
(.002)\end{array}$ & $\begin{array}{l}-0.003 \\
(.013)\end{array}$ & $\begin{array}{l}0.030 \\
(.013)\end{array}$ & $\begin{array}{l}0.017 \\
(.004)\end{array}$ & $\begin{array}{l}0.019 \\
(.003)\end{array}$ & $\begin{array}{l}0.025 \\
(.009)\end{array}$ & $\begin{array}{l}0.016 \\
(.009)\end{array}$ & $\begin{array}{l}0.029 \\
(.004)\end{array}$ & $\begin{array}{l}0.004 \\
(.003)\end{array}$ & $\begin{array}{l}0.006 \\
(.006)\end{array}$ & $\begin{array}{l}-0.002 \\
(.006)\end{array}$ & $\begin{array}{l}0.005 \\
(.002)\end{array}$ \\
\hline Age square $* 100$ & $\begin{array}{l}-0.001 \\
(.004)\end{array}$ & $\begin{array}{l}0.014 \\
(.022)\end{array}$ & $\begin{array}{l}-0.030 \\
(.021)\end{array}$ & $\begin{array}{l}-0.016 \\
(.006)\end{array}$ & $\begin{array}{l}-0.030 \\
(.005)\end{array}$ & $\begin{array}{l}-0.031 \\
(.014)\end{array}$ & $\begin{array}{l}-0.017 \\
(.014)\end{array}$ & $\begin{array}{l}-0.039 \\
(.006)\end{array}$ & $\begin{array}{l}0.000 \\
(.004)\end{array}$ & $\begin{array}{l}-0.004 \\
(.009)\end{array}$ & $\begin{array}{l}0.009 \\
(.009)\end{array}$ & $\begin{array}{l}-0.001 \\
(.003)\end{array}$ \\
\hline $\begin{array}{l}\text { Education lower than } 12 \\
\text { years }\end{array}$ & $\begin{array}{l}-0.066 \\
(.006)\end{array}$ & $\begin{array}{l}-0.076 \\
(.023)\end{array}$ & $\begin{array}{l}-0.054 \\
(.027)\end{array}$ & $\begin{array}{l}-0.094 \\
(.008)\end{array}$ & $\begin{array}{l}-0.079 \\
(.007)\end{array}$ & $\begin{array}{l}-0.082 \\
(.015)\end{array}$ & $\begin{array}{l}-0.070 \\
(.016)\end{array}$ & $\begin{array}{l}-0.079 \\
(.007)\end{array}$ & $\begin{array}{r}-0.026 \\
(.008)\end{array}$ & $\begin{array}{l}-0.017 \\
(.013)\end{array}$ & $\begin{array}{l}-0.029 \\
(.013)\end{array}$ & $\begin{array}{l}-0.032 \\
(.006)\end{array}$ \\
\hline Nonwhite & $\begin{array}{l}-0.088 \\
(.007)\end{array}$ & $\begin{array}{l}-0.165 \\
(.049)\end{array}$ & $\begin{array}{l}-0.151 \\
(.040)\end{array}$ & $\begin{array}{l}-0.121 \\
(.010)\end{array}$ & $\begin{array}{l}-0.134 \\
(.010)\end{array}$ & $\begin{array}{l}-0.097 \\
(.025)\end{array}$ & $\begin{array}{l}-0.112 \\
(.026)\end{array}$ & $\begin{array}{l}-0.121 \\
(.008)\end{array}$ & $\begin{array}{l}-0.137 \\
(.007)\end{array}$ & $\begin{array}{l}-0.146 \\
(.017)\end{array}$ & $\begin{array}{l}-0.122 \\
(.013)\end{array}$ & $\begin{array}{l}-0.104 \\
(.005)\end{array}$ \\
\hline Number of children & $\begin{array}{l}-0.004 \\
(.002)\end{array}$ & $\begin{array}{l}-0.011 \\
(.009)\end{array}$ & $\begin{array}{l}-0.030 \\
(.011)\end{array}$ & $\begin{array}{l}-0.017 \\
(.004)\end{array}$ & $\begin{array}{l}-0.018 \\
(.003)\end{array}$ & $\begin{array}{l}-0.020 \\
(.007)\end{array}$ & $\begin{array}{l}-0.023 \\
(.007)\end{array}$ & $\begin{array}{l}-0.018 \\
(.004)\end{array}$ & $\begin{array}{r}-0.002 \\
(.004)\end{array}$ & $\begin{array}{l}0.014 \\
(.007)\end{array}$ & $\begin{array}{l}0.008 \\
(.007)\end{array}$ & $\begin{array}{l}0.004 \\
(.003)\end{array}$ \\
\hline Age of the youngest child & $\begin{array}{l}0.012 \\
(.001)\end{array}$ & $\begin{array}{l}0.003 \\
(.004)\end{array}$ & $\begin{array}{l}-0.004 \\
(.004)\end{array}$ & $\begin{array}{l}0.003 \\
(.001)\end{array}$ & $\begin{array}{l}0.007 \\
(.001)\end{array}$ & $\begin{array}{l}0.002 \\
(.002)\end{array}$ & $\begin{array}{l}0.001 \\
(.002)\end{array}$ & $\begin{array}{l}0.002 \\
(.001)\end{array}$ & $\begin{array}{l}0.010 \\
(.001)\end{array}$ & $\begin{array}{l}0.009 \\
(.002)\end{array}$ & $\begin{array}{l}0.005 \\
(.002)\end{array}$ & $\begin{array}{l}0.006 \\
(.001)\end{array}$ \\
\hline $\begin{array}{l}\text { On welfare } 7-12 \text { months in } \\
\text { prior } 2 \text { years }\end{array}$ & $\begin{array}{l}-0.075 \\
(.006)\end{array}$ & $\begin{array}{l}-0.050 \\
(.028)\end{array}$ & $\begin{array}{l}-0.071 \\
(.030)\end{array}$ & $\begin{array}{l}-0.033 \\
(.008)\end{array}$ & $\begin{array}{l}-0.048 \\
(.006)\end{array}$ & $\begin{array}{l}-0.011 \\
(.018)\end{array}$ & $\begin{array}{l}-0.030 \\
(.019)\end{array}$ & $\begin{array}{l}-0.029 \\
(.006)\end{array}$ & $\begin{array}{l}-0.002 \\
(.006)\end{array}$ & $\begin{array}{l}0.001 \\
(.015)\end{array}$ & $\begin{array}{l}-0.034 \\
(.014)\end{array}$ & $\begin{array}{l}0.010 \\
(.006)\end{array}$ \\
\hline $\begin{array}{l}\text { On welfare } 13-23 \text { months } \\
\text { in prior } 2 \text { years }\end{array}$ & $\begin{array}{l}-0.133 \\
(.007)\end{array}$ & $\begin{array}{l}-0.125 \\
(.028)\end{array}$ & $\begin{array}{l}-0.105 \\
(.029)\end{array}$ & $\begin{array}{l}-0.086 \\
(.009)\end{array}$ & $\begin{array}{l}-0.095 \\
(.007)\end{array}$ & $\begin{array}{l}-0.077 \\
(.017)\end{array}$ & $\begin{array}{r}-0.070 \\
(.018)\end{array}$ & $\begin{array}{l}-0.064 \\
(.007)\end{array}$ & $\begin{array}{l}-0.040 \\
(.008)\end{array}$ & $\begin{array}{l}-0.047 \\
(.015)\end{array}$ & $\begin{array}{l}-0.044 \\
(.015)\end{array}$ & $\begin{array}{l}-0.020 \\
(.006)\end{array}$ \\
\hline $\begin{array}{l}\text { On welfare } 24 \text { months in } \\
\text { prior } 2 \text { years }\end{array}$ & $\begin{array}{l}-0.216 \\
(.007)\end{array}$ & $\begin{array}{l}-0.173 \\
(.031)\end{array}$ & $\begin{array}{l}-0.160 \\
(.032)\end{array}$ & $\begin{array}{l}-0.128 \\
(.011)\end{array}$ & $\begin{array}{l}-0.145 \\
(.009)\end{array}$ & $\begin{array}{l}-0.126 \\
(.021)\end{array}$ & $\begin{array}{l}-0.075 \\
(.022)\end{array}$ & $\begin{array}{l}-0.080 \\
(.009)\end{array}$ & $\begin{array}{r}-0.081 \\
(.009)\end{array}$ & $\begin{array}{l}-0.073 \\
(.019)\end{array}$ & $\begin{array}{l}-0.060 \\
(.020)\end{array}$ & $\begin{array}{l}-0.020 \\
(.008)\end{array}$ \\
\hline $\begin{array}{l}\text { Percent of previous } 8 \\
\text { quarters working }\end{array}$ & $\begin{array}{l}-0.028 \\
(.031)\end{array}$ & $\begin{array}{l}-0.156 \\
(.092)\end{array}$ & $\begin{array}{l}-0.224 \\
(.103)\end{array}$ & $\begin{array}{l}-0.153 \\
(.053)\end{array}$ & $\begin{array}{l}-0.037 \\
(.038)\end{array}$ & $\begin{array}{l}-0.062 \\
(.051)\end{array}$ & $\begin{array}{l}-0.113 \\
(.075)\end{array}$ & $\begin{array}{l}-0.091 \\
(.026)\end{array}$ & $\begin{array}{l}-0.320 \\
(.041)\end{array}$ & $\begin{array}{l}-0.062 \\
(.033)\end{array}$ & $\begin{array}{l}-0.168 \\
(.045)\end{array}$ & $\begin{array}{l}-0.129 \\
(.022)\end{array}$ \\
\hline $\begin{array}{l}\text { Working all of previous } 8 \\
\text { qtrs }\end{array}$ & $\begin{array}{c}-0.032 \\
(.014)\end{array}$ & $\begin{array}{l}0.008 \\
(.049)\end{array}$ & $\begin{array}{l}0.012 \\
(.039)\end{array}$ & $\begin{array}{l}-0.036 \\
(.014)\end{array}$ & $\begin{array}{l}-0.026 \\
(.014)\end{array}$ & $\begin{array}{l}0.015 \\
(.027)\end{array}$ & $\begin{array}{l}0.012 \\
(.023)\end{array}$ & $\begin{array}{l}0.007 \\
(.010)\end{array}$ & $\begin{array}{c}-0.103 \\
(.015)\end{array}$ & $\begin{array}{l}0.011 \\
(.020)\end{array}$ & $\begin{array}{c}-0.009 \\
(.018)\end{array}$ & $\begin{array}{l}0.003 \\
(.008)\end{array}$ \\
\hline $\begin{array}{l}\text { No work in any of previous } \\
8 \text { quarters }\end{array}$ & $\begin{array}{l}-0.010 \\
(.010)\end{array}$ & $\begin{array}{l}0.077 \\
(.052)\end{array}$ & $\begin{array}{l}0.030 \\
(.067)\end{array}$ & $\begin{array}{l}0.083 \\
(.037)\end{array}$ & $\begin{array}{l}0.023 \\
(.013)\end{array}$ & $\begin{array}{l}0.033 \\
(.028)\end{array}$ & $\begin{array}{l}-0.037 \\
(.043)\end{array}$ & $\begin{array}{l}0.047 \\
(.015)\end{array}$ & $\begin{array}{l}0.089 \\
(.015)\end{array}$ & $\begin{array}{l}0.025 \\
(.028)\end{array}$ & $\begin{array}{l}0.080 \\
(.034)\end{array}$ & $\begin{array}{l}0.080 \\
(.015)\end{array}$ \\
\hline $\begin{array}{l}\text { Total annual earnings in } \\
\text { the prior year } * 1000\end{array}$ & $\begin{array}{l}0.002 \\
(.003)\end{array}$ & $\begin{array}{l}0.016 \\
(.005)\end{array}$ & $\begin{array}{l}0.010 \\
(.004)\end{array}$ & $\begin{array}{l}0.002 \\
(.004)\end{array}$ & $\begin{array}{l}0.003 \\
(.003)\end{array}$ & $\begin{array}{l}0.014 \\
(.003)\end{array}$ & $\begin{array}{l}0.013 \\
(.002)\end{array}$ & $\begin{array}{l}0.009 \\
(.002)\end{array}$ & $\begin{array}{c}-0.028 \\
(.004)\end{array}$ & $\begin{array}{l}0.004 \\
(.002)\end{array}$ & $\begin{array}{l}0.005 \\
(.002)\end{array}$ & $\begin{array}{l}0.001 \\
(.001)\end{array}$ \\
\hline
\end{tabular}




\begin{tabular}{|c|c|c|c|c|c|c|c|c|c|c|c|c|}
\hline & \multicolumn{8}{|c|}{ Missouri } & \multirow{2}{*}{\multicolumn{4}{|c|}{$\begin{array}{c}\text { North Carolina } \\
1997\end{array}$}} \\
\hline & \multicolumn{4}{|c|}{1993} & \multicolumn{4}{|c|}{1997} & & & & \\
\hline & \multicolumn{4}{|c|}{ Job in Temp } & \multicolumn{4}{|c|}{ Job in Temp } & \multicolumn{4}{|c|}{ Job in Temp } \\
\hline & No Job & $\begin{array}{c}\text { Job in Temp } \\
\text { Help }\end{array}$ & $\begin{array}{l}\text { Help and } \\
\text { Other } \\
\text { Industry }\end{array}$ & $\begin{array}{c}\text { Job, but } \\
\text { none in } \\
\text { Temp Help }\end{array}$ & No Job & $\begin{array}{l}\text { Job in Temp } \\
\text { Help }\end{array}$ & $\begin{array}{l}\text { Help and } \\
\text { Other } \\
\text { Industry }\end{array}$ & $\begin{array}{c}\text { Job, but } \\
\text { none in } \\
\text { Temp Help }\end{array}$ & No Job & $\begin{array}{l}\text { Job in Temp } \\
\text { Help }\end{array}$ & $\begin{array}{l}\text { Help and } \\
\text { Other } \\
\text { Industry }\end{array}$ & $\begin{array}{c}\text { Job, but none } \\
\text { in Temp } \\
\text { Help }\end{array}$ \\
\hline \multirow{2}{*}{$\begin{array}{l}\text { Total annual earnings two } \\
\text { years prior } * 1000\end{array}$} & 0.003 & 0.008 & 0.005 & 0.010 & 0.008 & 0.006 & 0.006 & 0.006 & 0.020 & 0.004 & 0.006 & 0.008 \\
\hline & $(.002)$ & $(.004)$ & $(.004)$ & $(.003)$ & $(.002)$ & $(.002)$ & $(.003)$ & $(.001)$ & 0.002 .23 & $(.002)$ & $(.002)$ & $(.001)$ \\
\hline \multirow[t]{2}{*}{ St. Louis central } & -0.108 & -0.197 & -0.155 & -0.085 & -0.150 & -0.123 & -0.115 & -0.103 & na & na & na & na \\
\hline & $(.008)$ & $(.070)$ & $(.065)$ & $(.012)$ & $(.011)$ & $(.031)$ & $(.027)$ & $(.010)$ & & & & \\
\hline \multirow[t]{2}{*}{ Kansas City central } & -0.068 & -0.189 & -0.179 & -0.076 & -0.052 & -0.073 & -0.078 & -0.054 & na & na & na & na \\
\hline & $(.009)$ & $(.071)$ & $(.074)$ & $(.012)$ & $(.012)$ & $(.034)$ & $(.032)$ & $(.010)$ & & & & \\
\hline \multirow[t]{2}{*}{ Charlotte central } & na & na & na & na & na & na & na & na & -0.092 & -0.090 & -0.095 & -0.091 \\
\hline & & & & & & & & & $(0.013)$ & $(0.020)$ & $(0.020)$ & $(0.010)$ \\
\hline \multirow[t]{2}{*}{ Suburban metro } & -0.011 & -0.158 & -0.098 & -0.005 & 0.014 & -0.006 & -0.058 & -0.001 & -0.005 & 0.034 & -0.007 & 0.002 \\
\hline & $(.010)$ & $(.070)$ & $(.073)$ & $(.012)$ & $(0.011)$ & $(0.032)$ & $(0.029)$ & (0.009) & $(0.018)$ & $(0.026)$ & $(0.027)$ & $(0.012)$ \\
\hline \multirow[t]{2}{*}{ Small metro } & -0.001 & -0.079 & -0.092 & -0.022 & 0.007 & 0.021 & -0.022 & -0.005 & -0.018 & -0.009 & -0.047 & -0.029 \\
\hline & $(.011)$ & $(.058)$ & $(.064)$ & $(.012)$ & $(.011)$ & $(.028)$ & $(.030)$ & $(.009)$ & $(.007)$ & $(.013)$ & $(.013)$ & $(.005)$ \\
\hline \multirow[t]{2}{*}{ Quarter 2} & 0.004 & 0.006 & -0.016 & -0.010 & 0.006 & 0.027 & -0.002 & -0.003 & -0.010 & 0.012 & -0.019 & -0.002 \\
\hline & $(.002)$ & $(.015)$ & $(.025)$ & $(.007)$ & $(.003)$ & $(.011)$ & $(.019)$ & $(.003)$ & $(.004)$ & $(.010)$ & $(.012)$ & $(.003)$ \\
\hline \multirow[t]{2}{*}{ Quarter 3} & 0.010 & -0.008 & -0.043 & -0.013 & 0.001 & 0.016 & -0.013 & -0.005 & -0.008 & 0.018 & -0.020 & 0.008 \\
\hline & $(.004)$ & $(.022)$ & $(.035)$ & $(.010)$ & $(.005)$ & $(.014)$ & $(.021)$ & $(.004)$ & $(.006)$ & $(.012)$ & $(.015)$ & $(.004)$ \\
\hline \multirow[t]{2}{*}{ Quarter 4} & 0.026 & -0.003 & -0.042 & -0.001 & -0.002 & 0.006 & -0.026 & -0.025 & 0.029 & 0.026 & -0.012 & 0.027 \\
\hline & $(.004)$ & $(.024)$ & $(.036)$ & $(.010)$ & $(.005)$ & $(.014)$ & $(.021)$ & $(.005)$ & $(.004)$ & $(.012)$ & $(.015)$ & $(.004)$ \\
\hline \multirow[t]{2}{*}{ Lambda } & 0.074 & -0.173 & -0.150 & -0.158 & 0.064 & 0.041 & -0.001 & -0.053 & 0.457 & -0.105 & -0.112 & -0.134 \\
\hline & $(.040)$ & $(.135)$ & $(.127)$ & $(.072)$ & $(.053)$ & $(.067)$ & $(.084)$ & $(.033)$ & $(.054)$ & $(.053)$ & $(.045)$ & $(.027)$ \\
\hline $\mathrm{N}$ & 209,325 & 6,230 & 3,744 & 69,861 & 129,440 & 9,921 & 7,485 & 72,596 & 130,894 & 12,148 & 10,073 & 95,254 \\
\hline
\end{tabular}

Note: Standard erros are in parentheses. All standard errors have been adjusted for the estimation error in the inverse Mill's ratio. Estimation takes account of the correlation

of errors for recipients who appear in the data multiple times. 